\title{
EL BLOQUE DE CONSTITUCIONALIDAD COMO MECANISMO DE INTERPRETACIÓN CONSTITUCIONAL. APROXIMACIÓN A LOS CONTENIDOS DEL BLOgUE EN DERECHOS EN COLOMBIA*
}

\section{THE BLOC DE CONSTITUTIONNALITÉ AS A MECHANISM FOR CONSTITUTIONAL INTERPRETATION. AN APPROACH TO THE CONTENTS OF THE CORPUS OF RIGHTS IN COLOMBIA}

Vanessa Suelt-Cock**

Fecha de recepción: 15 de febrero de 2016

Fecha de aceptación: 15 de junio de 2016 Disponible en línea: 30 de noviembre de 2016

\section{Para citar este artículo/To cite this article}

\begin{abstract}
Suelt-Cock, Vanessa, El bloque de constitucionalidad como mecanismo de interpretación constitucional. Aproximación a los contenidos del bloque en derechos en Colombia, 133 Vniversitas, 301-382 (2016). http://dx.doi. org/10.11144/Javeriana.vj133.bcmi

doi:10.11144/Javeriana.vj133.bcmi
\end{abstract}

* Este artículo es producto del proyecto de investigación El impacto en el derecho al territorio de las violaciones de derechos humanos por parte de empresas de la industria extractiva en Colombia, de la línea de investigación Constitución y Justicia del grupo de Estudios en Derecho Público de la Facultad de Ciencias Jurídicas, Pontificia Universidad Javeriana.

** Abogada y especialista en derecho administrativo, Pontificia Universidad Javeriana. Doctora en derecho público, Universidad de Salamanca, España. Profesora investigadora y directora del doctorado en ciencias jurídicas, Pontificia Universidad Javeriana. Contacto: vsuelt@ javeriana.edu.co 


\section{RESUMEN}

En este artículo me propongo exponer cómo el concepto de bloque de constitucionalidad en Colombia, al igual que todas las instituciones jurídicas occidentales obedece a circunstancias de tiempo y lugar determinadas. Asimismo, realizar una aproximación de los contenidos en derechos del Bloque de acuerdo a pronunciamientos de la Corte Constitucional. Para lograr estos dos cometidos describo el concepto de bloque ideado en Francia y España demostrando las diferencias de los conceptos ligadas a las circunstancias de contexto en el que esta figura se idea y el contraste con el caso colombiano. Este estudio permite señalar que se ha ampliado la constitución colombiana en materia de derechos humanos de acuerdo con la teoría del pluralismo constitucional y la interpretación multinivel. Esto ha implicado cambios en la interpretación constitucional para la aplicación de derechos humanos, debido a las nuevas relaciones entre las fuentes del derecho constitucional y las del internacional.

Palabras clave: Bloque de constitucionalidad; interpretación; tratados internacionales; derechos humanos 


\section{ABSTRACT}

The aim of the following article is to explain how the concept of Bloc de constitutionnalité in Colombia, as is the case with all other occidental juridical institutions, is partially determined by spatial and temporal circumstances. Another objective is to approach the contents of the Bloc form the standpoint of recent rulings from the Constitutional court. In order to achieve these two objectives I describe the concept of Bloc as introduced in France and Spain showing their differences and their relation to their circumstances and context, and how this contrasts to the Colombian case. This study allows me to affirm that the Colombian constitution has been expanded in relation to human rights in agreement with the principle of constitutional pluralism and multilevel interpretation. This has brought a change in the constitutional interpretation of how to apply human rights due to the new relations between the sources of constitutional law and those of international law.

Keywords: Bloc De Constitutionnalité; constitutional interpretation; international treaties; human rights

\section{SUMARIO}

Introducción.- I. Concepto Del Bloque De CONSTitucionalidad EN Francia.- A. Particularidad del concepto de bloque de constitucionalidad en un ordenamiento complejo como el español.- II. EL BLOQUE DE CONSTItucionalidad en Colombia.- $A$. Configuración del bloque constitucional $y$ contenidos. -1 . Los tratados internacionales, guía de la interpretación constitucional.- 2. Convenios de la OIT, consulta previa y derecho a la salud.- 3. Derecho a la no discriminación de las mujeres, derechos reproductivos y protección frente a la violencia.- 4. Protección del derecho a la vida y protección frente al desplazamiento forzado.- 5. Derechos de los niños.- B. Reconocimiento de derechos innominados e interpretación ampliada de derechos.- Conclusiones.- Bibliografía. 


\section{INTRODUCCIÓN}

Después de la Segunda Guerra Mundial, en su mayoría, los estados liberales introdujeron constitucionalmente capítulos sobre derechos humanos y mecanismos para hacerlos efectivos ${ }^{1}$, y optaron por sistemas de control concentrado de constitucionalidad de acuerdo al modelo austriaco de preguerra ${ }^{2}$, por medio de un Tribunal Constitucional que hacía un examen judicial de oficio de las leyes. Este movimiento constitucional europeo estuvo a su vez influenciado por declaraciones internacionales de derechos humanos ${ }^{3}$. Así, las constituciones liberales europeas reconocieron derechos civiles, políticos, libertades y derechos sociales, cuyas formulaciones variaron entre sí: desde enunciación de derechos como los artículos 1 a 20 de la Ley Fundamental de Bonn ${ }^{4}$, hasta listas más detalladas como las que se presentan en Francia, Italia y España 5 .

El reconocimiento de libertades negativas y derechos afirmativos de contenido social en las Constituciones europeas de posguerra ${ }^{6}$

1 Louis Favoreu, American and European Models of Constitutional Justice, en Comparative and Private International Law: Essays in honor of John Henry Merryman on his Seventieth Birthday, 105-120 (David S. Clark, ed., Duncker \& Humblot, Berlin, 1990), citado por MarY Ann Glendon, Rights in Twentieth-Century Constitutions, 59 The University of Chicago Law Review, 1, The Bill of Rights in the Welfare State: A Bicentennial Symposium, held at The University of Chicago Law School on October 25-26, 1991, 519-538, 523 (1992). Disponible en: http://chicagounbound.uchicago.edu/cgi/viewcontent.cgi?article $=4760 \&$ context $=$ uclrev

2 Los integrantes de ese tribunal constitucional son elegidos por el parlamento para garantizar y controlar la democracia. Hans Kelsen, ¿Quién debe ser el defensor de la Constitución? (Tecnos, Madrid, 1931-1995) [Wer soll Hüter der Verfassung sein?, 6 Die Justiz, 576-628 (1931)].

3 Organización de Naciones Unidas, ONU, Declaración Universal de Derechos Humanos, París, 10 de diciembre de 1948, artículos 22 y 25. Disponible en: http://www.un.org/es/documents/ udhr/. Organización de Naciones Unidas, ONU, Pacto Internacional de Derechos Económicos, Sociales y Culturales, 16 de diciembre de 1966. Disponible en: http://www.ohchr.org/SP/ ProfessionalInterest/Pages/CESCR.aspx. MARy Ann Glendon, Rights in Twentieth-Century Constitutions, 59 The University of Chicago Law Review, 1, The Bill of Rights in the Welfare State: A Bicentennial Symposium, held at The University of Chicago Law School on October 25-26, 1991, 519-538, 526 (1992). Disponible en: http://chicagounbound.uchicago.edu/cgi/ viewcontent.cgi?article $=4760 \&$ context $=$ uclrev

4 Alemania, Ley Fundamental de la República Federal de Alemania [Grundgesetz für die Bundesrepublik Deutschland], Ley Fundamental de Bonn, 23 de mayo de 1949. Versión actualizada a 2010 disponible en: https://www.btg-bestellservice.de/pdf/80206000.pdf, https:// www.bundestag.de/grundgesetz

5 Mary Ann Glendon, Rights in Twentieth-Century Constitutions, 59 The University of Chicago Law Review, 1, The Bill of Rights in the Welfare State: A Bicentennial Symposium, held at The University of Chicago Law School on October 25-26, 1991, 519-538, 526 (1992). Disponible en: http://chicagounbound.uchicago.edu/cgi/viewcontent.cgi?article $=4760 \&$ context $=u c l r e v$

6 La pregunta por el contenido social de los derechos está en cómo compensar la falta de igualdad social respecto de la libertad económica, característica de las constituciones liberales. Franz Wieacker \& Edgar Bodenheimer, trad., Foundations of European Legal Culture, 38 
contrastaba con el tipo de consagración que se realizaba en el siglo XIX en la que se reconocían obligaciones del Estado para proveer comida, trabajo y ayudas económicas a personas necesitadas ${ }^{7}$. Se trataba de reconocimientos de libertades negativas para proteger al individuo de la interferencia estatal. En esta tendencia se inserta, a su vez, la Constitución de Estados Unidos ${ }^{8}$.

El cambio en la tradición de la constitucional liberal, de consagrar derechos y mecanismos para su protección, puede explicarse por la adopción del Estado Social. En este Estado, como señala Franz WiEACKer, "el principio de la solidaridad social fue legitimado por la garantía constitucional y la implementación de los derechos sociales para los más vulnerables de la sociedad”. Otros autores han señalado que su consagración y la garantía de los derechos civiles y políticos han permitido el tránsito, por el acuerdo constitucional, de Estados autoritarios a democráticos en el este de Europa, la finalización de las dictaduras de España y Portugal y en América Latina9.

Las Constituciones sellan esos pactos de la transición hacia la democracia, en los que adquiere una especial relevancia la consagración de derechos y su protección, siendo uno de los tópicos de mayor desarrollo y debate en los tribunales constitucionales contemporáneos.

La consagración de derechos y la extensión de la creación de tribunales constitucionales en los Estados liberales han implicado una revisión de las fuentes del derecho interno, respecto del derecho internacional y de los mecanismos que prevén la integración de fuentes internacionales. En lo que respecta a los tratados de derechos humanos, en diversos países se han creado mecanismos de interpretación que faciliten su incorporación en el derecho in-

The American Journal of Comparative Law, 1, 1-29 (Winter, 1990).

7 Franz Wieacker \& Edgar Bodenheimer, trad., Foundations of European Legal Culture, 38 The American Journal of Comparative Law, 1, 1-29 (Winter, 1990).

8 Estados Unidos de América, Constitución, 7 de septiembre de 1787, ratificada 21 de junio de 1788. Disponible en: http://www.archives.gov/espanol/constitucion.html, http://www.senate. gov/civics/constitution_item/constitution.htm

9 Diego Eduardo López-Medina \& Astrid Liliana SÁnchez-Mejía, La armonización del derecho internacional de los derechos humanos con el derecho penal colombiano, 6 International Law: Revista Colombiana de Derecho Internacional, ILDI, 12, 317-352 (Edición Especial: 60 Años de la Declaración Universal de Derechos Humanos y 30 años de entrada en vigencia de la Convención Americana de Derechos Humanos, 2008). Disponible en: http://revistas.javeriana. edu.co/index.php/internationallaw/article/view/13929/11217 
terno para lograr su efectividad. En Colombia, ello conduce a la creación de un bloque de constitucionalidad en materia de derechos como parámetro de control de constitucionalidad que incorpora los tratados de derechos humanos y que no puede suspenderse en estados de excepción ${ }^{10}$.

Para comprender figuras interpretativas como el bloque de constitucionalidad, puede acudirse a la teoría de la Constitución $\mathrm{Red}^{11}$. Esta teoría parte de entender la Constitución acorde con las circunstancias históricas, su entorno cultural y normativo, como ha sido expresado por "[José JoAQuim] Gomes CANOTILHo, un sistema jurídico en cuanto sistema dinámico de normas, es un sistema abierto porque su estructura permite la capacidad de aprendizaje de las normas constitucionales y captar, así los cambios en la realidad, y, por último, ese sistema jurídico abierto se muestra bajo la forma de principios y reglas, ambos de naturaleza plenamente jurídica"12.

La apertura de la Constitución puede ser una apertura "horizontal referente al carácter fragmentario y no codificador del texto constitucional y de una apertura vertical atinente al carácter general e indeterminado de muchas normas constitucionales que, precisamente por eso, se abren a la actuación de los poderes constituidos"13. Esta forma de entender la Constitución es propia del pluralismo de la sociedad actual, así, los principios y valores son una representación dinámica de la Constitución acorde con el contexto cultural, político y económico ${ }^{14}$. A ello debe añadirse la comprensión del constitucionalismo en múltiples niveles que RAFAEL Bustos-GisBert describe así: "la norma constitucional nacional ha dejado de ser inmune frente a las normas extraestatales y se han

10 Como lo disponen: Organización de Naciones Unidas, ONU, Pacto Internacional de Derechos Económicos, Sociales y Culturales, 16 de diciembre de 1966, artículos 4.1 y 4.2. Disponible en: http://www.ohchr.org/SP/ProfessionalInterest/Pages/CESCR.aspx. Organización de Estados Americanos, OEA, Convención Americana sobre Derechos Humanos, Pacto de San José, San José, Costa Rica, 7 al 22 de noviembre de 1969, artículo 27, suspensión de garantías. Disponible en: https://www.oas.org/dil/esp/tratados_B-32_Convencion_Americana_sobre_Derechos_Humanos.htm

11 Rafael Bustos-Gisbert, La Constitución Red: un estudio sobre supraestatalidady Constitución, 178 y ss. (Instituto Vasco de Administración Pública, Oñati, 2005).

12 Rafael Bustos-Gisbert, La Constitución Red: un estudio sobre supraestatalidady Constitución, 38 (Instituto Vasco de Administración Pública, Oñati, 2005).

13 Rafael Bustos-Gisbert, La Constitución Red: un estudio sobre supraestatalidady Constitución, 38 (Instituto Vasco de Administración Pública, Oñati, 2005).

14 Rafael Bustos-Gisbert, La Constitución Red: un estudio sobre supraestatalidady Constitución, 44 (Instituto Vasco de Administración Pública, Oñati, 2005). 
creado normas de naturaleza constitucional en ámbitos territoriales supraestatales y sectorialmente limitados a un concreto grupo de funciones o competencias"15. "Las normas constitucionales, por tanto, han perdido su exclusividad y existen nuevas estructuras de poder complementarias y construidas sobre las formas preexistentes de autoorganización de los ciudadanos"16.

La Constitución Red presupone la apertura de las constituciones a la cooperación internacional y a la integración supranacional de las constituciones estatales, esto ha permitido la aparición de otros espacios, los metaconstitucionales, estructuras supraestatales de carácter postestatal en las que el Estado constitucional ha decidido participar y ejercer su poder político. En estas instancias se producen verdaderas normas constitucionales supraestatales que se sitúan al mismo nivel que las normas constitucionales nacionales. Entre estas normas no se establecen relaciones de jerarquía, sino de recíproca interdependencia, complementariedad y mutua influencia ${ }^{17}$. Esta relación dependerá de cómo se haya planteado en la Constitución y cómo esto se relaciona con los aspectos socioculturales de la misma. Cuanto mayor sea la homogeneidad entre el planteamiento estructural en la Constitución, la regulación del ente o mandato supraestatal y los aspectos socioculturales, mayor será la interrelación entre los diferentes espacios y lugares constitucionales. La Constitución es la que establece las cláusulas de apertura y el

15 Rafael Bustos-Gisbert, La Constitución Red: un estudio sobre supraestatalidady Constitución, 177 (Instituto Vasco de Administración Pública, Oñati, 2005).

16 El constitucionalismo de múltiples niveles ha sido desarrollado entre otros por INGOLF PERNICE \& Franz C. MaYer, De la Constitution composée de l'Europe, 1-27 (Walter Hallstein Institut für Europäisches Verfassungsrecht, WHI, 1/2001)). Disponible en: http://www.whi-berlin.eu/ documents/whi-paper0101.pdf. Peter HÄBERle, Pluralismo y Constitución: estudios de teoría constitucional de la sociedad abierta, 104 (Emilio Mikunda-Franco, trad., Tecnos, Madrid, 2002). Miguel Maduro-Poiares, Three Claims of Constitutional Pluralism, en Constitutional Pluralism in the European Union and Beyond, 67-84 (Matej Avbelu \& JAn KomÁrek, eds., Hart Publishing, Oxford, Portland, 2012). Texto disponible en: https://www.wzb.eu/sites/default/ files/veranstaltungen/the-promise-of-constitutional-pluralism/miguelmadurothreeclaimsof constitutionalpluralismhu-collmay152012.pdf. NeIL MACCORMICK, Beyond the Sovereign State, 56 The Modern Law Review, 1, 1-18 (1993). Disponible en: http://onlinelibrary.wiley. com/doi/10.1111/j.1468-2230.1993.tb02851.x/epdf

17 En su libro, el profesor Bustos-GisBERT hace relación particularmente a las normas constitucionales europeas que no están en superioridad jerárquica y generan transformaciones. A su vez, las tradiciones constitucionales comunes de los Estados son adoptadas en los espacios supraestatales. Rafael Bustos-GisBert, La Constitución Red: un estudio sobre supraestatalidad y Constitución, 182 (Instituto Vasco de Administración Pública, Oñati, 2005). 
mutuo reconocimiento de otros lugares constitucionales, como los tratados internacionales ${ }^{18}$.

Sobre ello, NeIL MacCormick sostuvo que nos encontramos en una era de complejidad legal por los diversos entes que emiten normas que obligan a los Estados. Se trata de comprender un derecho más amplio y difuso. "Esta es una visión que permite la posibilidad de que diferentes sistemas se superpongan e interactúen entre sí, sin que necesariamente se requiera que uno de ellos esté subordinado a otro o que sea jerárquicamente inferior a este o a un tercer sistema"19.

De acuerdo con ello, la interrelación e integración del derecho internacional, desde el punto de vista del derecho constitucional, pueden hacerse efectivas con los mecanismos de control de constitucionalidad y de amparo en los sistemas nacionales. Así, el control de constitucionalidad se sujeta a dos premisas; la primera, que la producción legislativa está limitada a la concordancia con la norma suprema; y en segundo lugar, que las pautas establecidas en la Constitución solo se pueden desarrollar por otras fuentes normativas de diversa jerarquía ${ }^{20}$. Esta última premisa, en relación con la Constitución Red, permite comprender que las fuentes de control de constitucionalidad son más amplias que las dispuestas en la norma de normas y que pueden incluir otras normas, entre ellas, las internacionales ${ }^{21}$. Al respecto, se ha comprendido que diversas fuentes pueden hacer parte del control de constitucionalidad; esto constituye una "ampliación del parámetro de control" que se ha entendido como "bloque de constitucionalidad". No obstante, el concepto y el contenido de lo que se comprende por bloque varía de país a país; como lo ha señalado un sector doctrinal, esto conlleva que no puede "ser institucionalizada como categoría jurídico-normativa y que ni

18 Rafael Bustos-Gisbert, La Constitución Red: un estudio sobre supraestatalidad y Constitución, 190 y ss. (Instituto Vasco de Administración Pública, Oñati, 2005).

19 Neil MacCormick, Beyond the Sovereign State, 56 The Modern Law Review, 1, 1-18, 8 (1993). Disponible en: http://onlinelibrary.wiley.com/doi/10.1111/j.1468-2230.1993.tb02851.x/epdf

20 Riccardo Guastini, La Costituzione come limite alla legislazione, en Analisi e diritto 1998. Ricerche di giurisprudenza analitica, 107-114 (PAolo Comanducci \& Riccardo Guastini, eds., Giappichelli Editore, Torino, 1998).

21 Sobre la estructura cada vez más compleja del parámetro en el proceso de inconstitucionalidad de las leyes, la síntesis de Eliseo Aja-Fernández \& Markus GonzÁlez-Beilfuss, Conclusiones generales, en Las tensiones entre el Tribunal Constitucional y el Legislador en la Europa actual, 266-272 (Eliseo AJA-FernándeZ, ed., Editorial Ariel, Barcelona, 1998). 
siquiera tenga un significado preciso generalmente aceptado"22. El contenido del bloque de constitucionalidad varía a su vez de Estado a Estado; puede comprender normas materialmente o formalmente constitucionales; diversas normas con rango jerárquico inferior a la Constitución pero superior en el ordenamiento jurídico; normas que desarrollan la organización territorial de un Estado; normas que regulan los órganos superiores de un Estado; la jurisprudencia de altas cortes internacionales y observaciones de organismos internacionales, entre otros contenidos.

El caso colombiano ha irradiado al continente la forma en que son interpretados los derechos y la protección de la Constitución. Durante los primeros diez años de la Constitución de $1991^{23}$, la Corte Constitucional colombiana desarrolló el concepto del bloque de constitucionalidad, de acuerdo a las remisiones normativas que incorporaban el derecho internacional mediante los artículos 93, 94, 101 y 214 de la Constitución. La primera aproximación y delimitación del bloque permitía una comprensión de la Constitución más allá de sus contenidos formales y materiales, posición que fue duramente criticada por generar una apertura indefinida de la Constitución, y porque no se conocía qué hacía parte del bloque y qué no, lo que generaba una inseguridad jurídica innecesaria ${ }^{24}$. Otras críticas señalaban que la figura del bloque podía permitir interpretaciones demasiado laxas que terminarían vulnerando la Constitución.

Ahora bien, el bloque de constitucionalidad define en el caso colombiano los parámetros del control de constitucionalidad, es decir, determina qué tratados de derechos humanos componen ese parámetro y cuáles son los nuevos derechos que amplían la interpretación constitucional.

22 Louis Favoreu \& Francisco Rubio-Llorente, Bloque de constitucionalidad (Derecho Constitucional), en Enciclopedia Jurídica Básica, t. 1, 817 (Civitas, Madrid, 1995).

23 Colombia, Constitución Política, segunda edición corregida, 116 Gaceta Constitucional, 20 de julio de 1991. Disponible en: http://www.secretariasenado.gov.co/senado/basedoc/constitucion_politica_1991.html

24 Rodrigo UprimnY-YePes, El bloque de constitucionalidad en Colombia. Un análisis jurisprudencial y un ensayo de sistematización doctrinal, Curso de formación de promotores/as en derechos humanos, libertad sindical y trabajo decente (Universidad Nacional, Escuela Nacional Sindical, ENS Colombia, Bogotá, 2005). Disponible en: http://redescuelascsa.com/sitio/repo/ DJS-Bloque_Constitucionalidad(Uprimny).pdf 
Se destaca que una de las características constantes en los contenidos del bloque es la integración en una unidad normativa de diversos tipos de normas. Este conjunto normativo sirve de base para confrontar una norma del ordenamiento jurídico y determinar su validez. Así, en Francia, Louis FAvOREu señaló que el juez constitucional había logrado "lo que dos siglos de historia no habían conseguido llevar a cabo: un conjunto constitucional suficientemente armonioso y coherente, que combina la modernidad y las tradiciones y en el que, sobre todo, los derechos fundamentales han sido finalmente integrados" 25 .

En el caso colombiano, a partir de la Constitución de 1991, el conjunto normativo que contempla el bloque lo componen tratados internacionales de derechos humanos. Con la Constitución anterior, de $1886^{26}$, la Corte Suprema de Justicia, sala constitucional, no consideró posible la inconstitucionalidad de una norma por violar un tratado internacional de derechos humanos ratificado por el Estado, en especial en temas laborales y de derechos sociales, económicos y culturales ${ }^{27}$. La introducción del bloque de constitucionalidad supuso, en este sentido, una nueva visión sobre la garantía de los derechos humanos en la legislación interna y la necesidad de que la normativa sea coherente con ese cuerpo internacional, pero también la introducción del discurso internacional en el contex to colombiano de los derechos humanos y de derecho internacional humanitario y la necesidad de coherencia entre la legislación interna y estos para garantizar su protección .

Por esta razón, y dada la importancia que adquiere como figura de interpretación y control constitucional, en este escrito se describirá brevemente el concepto de bloque en Francia y en España. Por contraste a estos dos casos, se estudia el colombiano. En este último caso, nos detendremos en los desarrollos jurisprudenciales más recientes, para realizar una aproximación sobre los contenidos

25 Louis Favoreu \& Francisco Rubio-Llorente, Bloque de constitucionalidad (Derecho Constitucional), en Enciclopedia Jurídica Básica, t. 1, 42 (Civitas, Madrid, 1995).

26 Colombia, Constitución Política, 5 de agosto de 1886. Disponible en: http://www.alcaldiabogota. gov.co/sisjur/normas/Norma1.jsp?i=7153

27 Rodrigo UprimnY-YePEs, El bloque de constitucionalidad en Colombia. Un análisis jurisprudencial y un ensayo de sistematización doctrinal, Curso de formación de promotores/as en derechos humanos, libertad sindical y trabajo decente (Universidad Nacional, Escuela Nacional Sindical, ENS Colombia, Bogotá, 2005). Disponible en: http://redescuelascsa.com/sitio/repo/ DJS-Bloque_Constitucionalidad(Uprimny).pdf 
del bloque de constitucionalidad en derechos, y apreciar la contradicción de sus contenidos. Se hará énfasis en los derechos que ha permitido unificar; ello, a la luz del marco teórico de las constituciones de posguerra, el pluralismo constitucional y la Constitución Red. Con esto podrá comprenderse su utilidad y cómo el parámetro de control de constitucionalidad se ha ampliado para dejar cláusulas abiertas y procurar una gran flexibilidad en la Constitución. Esta investigación por último permite comprender la adaptación de las constituciones a la cultura y el entorno, en este caso facilitar la introducción del discurso de los derechos humanos en Colombia $\mathrm{y}$, aunque lenta, su protección judicial.

\section{EL CONCEPTO DE BLOQUE DE CONSTITUCIONALIDAD EN FRANCIA}

Como es sabido, Louis FAvoreu utilizó la expresión bloque de constitucionalidad para explicar la Decisión DC 71-44 del 16 de julio de 1971 del Consejo Constitucional Francés ${ }^{28}$. En ese trabajo, FAVOREU resaltaba "una decisión innovadora del Consejo Constitucional, con la cual declaró la inconstitucionalidad de una ley que modificaba una disposición legislativa de 1901, limitando el régimen de las asociaciones. Para declarar su inconstitucionalidad, el Consejo consideró que la ley cuestionada debía ser analizada no solo a partir de la Constitución francesa de 1958, sino, tomando como norma paramétrica a la Declaración Francesa de los Derechos del Hombre y del Ciudadano de 1789"29. Con el fin de justificar esa ampliación del parámetro de constitucionalidad con una norma diversa a la Constitución, el Consejo sostuvo que, si bien formalmente la Decla-

28 Louis Favoreu \& Loïc Philip, Les grandes décisions du Conseil Constitutionnel, 239-254 (Sirey, Paris, 1986). Francia, Conseil Constitutionnel, Décision 71-44 DC du 16 juillet 1971, Loi complétant les dispositions des articles 5 et 7 de la loi du 1 juillet 1901 relative au contrat d'association, Journal Officiel, 18 juillet 1971. Disponible en: http://www.conseil-constitutionnel. fr/conseil-constitutionnel/francais/les-decisions/acces-par-date/decisions-depuis-1959/1971/7144-dc/decision-n-71-44-dc-du-16-juillet-1971.7217.html

29 LOUIS FAVOREU, Le principe de constitutionnalité: essai de définition d'après la jurisprudence du Conseil constitutionnel, en Recueil d'études en hommage à Charles Eisenmann, 33-48 (Mélanges, Éditions Cujas, Paris, 1975). La referencia al bloque de constitucionalidad, citado por ÉDGAR CARPio-Marcos, Bloque de constitucionalidad y proceso de inconstitucionalidad de las leyes, 4 Revista Iberoamericana de Derecho Procesal Constitucional, 79-114 (2005). Disponible en: https://works.bepress.com/edgar_carpio_marcos/1/ 
ración de $1789^{30}$ constituía un documento distinto a la Constitución de $1958^{31}$, esta era aludida directamente por su preámbulo.

El hecho de que el Consejo Constitucional tomara como base de control previo de constitucionalidad un documento diferente de la Constitución no tenía cómo explicarse jurídicamente; por ello, LouIs FAVOREu utilizó una figura proveniente del derecho administrativo: el bloque de legalidad, para idear el concepto del bloque de constitucionalidad, que solo se usó doctrinalmente. La palabra bloque denota unidad y solidez, un conjunto de algo que no puede ser dividido ${ }^{32}$.

Además de integrar normas que no hacían parte de la Constitución por referencia del preámbulo de 1958, en las primeras decisiones sobre el tema, el Consejo Constitucional francés en los años $60 \mathrm{y}$ 70 utilizó de modo amplio la expresión principios fundamentales reconocidos por las leyes de la República, esto "constituyó un medio útil para designar todo lo que tiene valor constitucional sin estar verdaderamente inscrito en la Declaración de Derechos y en el Preámbulo de 1946"33 34 . Así en dos decisiones de 1979, el Consejo consagró dos principios de rango constitucional: la separación de poderes y la continuidad de los servicios públicos. Esta denominación de principios con rango constitucional fue muy criticada por la doctrina, entre ellos, la jurista DANIĖLE LOCHAK, quien sostuvo que se trataba de "principios ilocalizables y de geometría variable" 35 , lo que aumenta el poder del Consejo Constitucional.

30 Francia, Declaración de los Derechos del Hombre y del Ciudadano de 1789 [Déclaration des Droits de l'Homme et du Citoyen de 1789]. Disponible en: http://www.conseil-constitutionnel. fr/conseil-constitutionnel/root/bank_mm/espagnol/es_ddhc.pdf, https://www.legifrance.gouv. fr/Droit-francais/Constitution/Declaration-des-Droits-de-1-Homme-et-du-Citoyen-de-1789

31 Francia, Constitución, 4 de octubre de 1958 [Texte intégral de la Constitution du 4 octobre 1958 en vigueur]. Disponible en: http://www.justice.gouv.fr/art_pix/constitution-espagnol_ juillet2008.pdf, http://www.conseil-constitutionnel.fr/conseil-constitutionnel/francais/ la-constitution/la-constitution-du-4-octobre-1958/texte-integral-de-la-constitution-du-4octobre-1958-en-vigueur.5074.html

32 Louis Favoreu \& Francisco Rubio-Llorente, Bloque de constitucionalidad (Derecho Constitucional), en Enciclopedia Jurídica Básica, t. 1, 20 (Civitas, Madrid, 1995).

33 Louis Favoreu \& Francisco Rubio-Llorente, Bloque de constitucionalidad (Derecho Constitucional), en Enciclopedia Jurídica Básica, t. 1, 22 (Civitas, Madrid, 1995).

34 Francia, Constitución, 27 de octubre de 1946 [Constitution de 1946, IV République]. Disponible en: http://www.conseil-constitutionnel.fr/conseil-constitutionnel/francais/la-constitution/ les-constitutions-de-la-france/constitution-de-1946-ive-republique.5109.html

35 Louis Favoreu \& Francisco Rubio-Llorente, Bloque de constitucionalidad (Derecho Constitucional), en Enciclopedia Jurídica Básica, t. 1, 22 (Civitas, Madrid, 1995). 
Tras la llegada del decano Georges Vedel al Consejo Constitucional [29 de febrero de 1980-28 de febrero de 1989], esta corporación asumió la doctrina de mesura en las decisiones sobre fuentes de carácter constitucional; así, el decano señaló que el Consejo debe estar alerta frente a decisiones que puedan constituirse como un "gobierno de los jueces", debido a que el juez no es el dueño de las fuentes del derecho constitucional ${ }^{36}$.

En este sentido, a partir de los años 80, comenzó una restricción de las decisiones en cuanto a qué constituye o no un parámetro de control formalmente constitucional, pues consideró que el bloque stricto sensu se compone únicamente de textos con nivel constitucional: la Constitución de 1958; el Preámbulo de la Constitución de 1946; la Declaración de Derechos del Hombre y el Ciudadano de 1789 y las leyes de la República cuando "sean portadoras de principios fundamentales" ${ }^{37}$. Los siguientes son los contenidos normativos del bloque:

- De la Constitución de 1958, hacen parte del bloque las disposiciones contenidas en los artículos 1 a 92, la mayoría de los cuales se refieren a derechos y libertades fundamentales, a saber "la laicidad, libertad de conciencia, no discriminación por razón de origen, raza o religión (artículo 2); derecho de los ciudadanos (artículo 3); partidos políticos (artículo 4); independencia de la magistratura (artículo 64); libertad individual y protección de la autoridad judicial"'38.

- De la Declaración de los Derechos del Hombre y el Ciudadano, el Consejo Constitucional ha aplicado su totalidad para anular leyes de la República que la contravenían, por ejemplo la decisión del 27 de diciembre de 1973 que invalidó la ley de finanzas ${ }^{39}$. La mayoría de ellos se inserta en la categoría de los derechos civiles y políticos.

36 Louis Favoreu \& Francisco Rubio-Llorente, Bloque de constitucionalidad (Derecho Constitucional), en Enciclopedia Jurídica Básica, t. 1, 23 (Civitas, Madrid, 1995).

37 Louis Favoreu \& Francisco Rubio-Llorente, Bloque de constitucionalidad (Derecho Constitucional), en Enciclopedia Jurídica Básica, t. 1, 24 (Civitas, Madrid, 1995).

38 Louis Favoreu \& Francisco Rubio-Llorente, Bloque de constitucionalidad (Derecho Constitucional), en Enciclopedia Jurídica Básica, t. 1, 24 (Civitas, Madrid, 1995).

39 Francia, Conseil Constitutionnel, Décision 73-51 DC du 27 décembre 1973, Loi de finances pour 1974, Journal Officiel, 28 décembre 1973. Disponible en: http://www.conseil-constitutionnel. fr/conseil-con..decision-n-73-51-dc-du-27-decembre-1973.7368.html 
- El preámbulo de 1946 es una declaración de derechos económicos y sociales que integra la Constitución de Francia y que también ha sido aplicado directamente por el Consejo Constitucional francés.

- Las leyes de la República cuando contengan principios fundamentales. En este caso, el Consejo Constitucional francés ha restringido considerablemente lo que a ello se refiere, debido a las críticas sobre el poder del juez y su papel realizadas particularmente por la doctrina francesa, por ejemplo, el profesor Vedel. Así desde la década de los 80, el Consejo ha señalado las condiciones para que las leyes puedan contener estos principios, a saber:

q. Debe tratarse de textos legislativos producidos durante "la República" lo que descarta las normas producidas por otros regímenes a lo largo de la historia francesa moderna y, debe haberse expedido antes del preámbulo de 1946.

r. "No puede haber ninguna excepción a la tradición (republicana) instaurada al socaire de las diversas leyes aprobadas, puesto que si una sola se desviara de ella dicha tradición no podía contemplarse como generadora de un principio fundamental reconocido por las leyes de la República en el sentido del párrafo 1 del Preámbulo de 1946".

s. El número de principios es limitado por el Consejo Constitucional, entre los cuales ha reconocido: la libertad de asociación: los derechos de defensa; la libertad individual; la libertad de enseñanza; la libertad de conciencia; la independencia de la jurisdicción administrativa; la independencia de los profesores de la Universidad; la competencia exclusiva de la jurisdicción administrativa en materia de anulación de actos de la autoridad pública; la autoridad judicial guardián de la propiedad privada ${ }^{40}$.

40 Ver el número de las decisiones en Louis Favoreu \& Francisco Rubio-Llorente, Bloque de constitucionalidad (Derecho Constitucional), en Enciclopedia Jurídica Básica, t. 1, 32 y ss. (Civitas, Madrid, 1995). Como señalan FAVOreu y Rubio-LLorente, hasta comienzos de los años 90, solo en 6 ocasiones se han invalidado las leyes con base en estos principios. Y solo cinco principios se aplican como leyes constitucionales, es decir, ocupan un lugar muy limitado en el bloque. Empezando los años 90, se declararon nuevos principios entre ellos el principio de sinceridad presupuestal que fue creado mediante la sentencia 93-320, de 21 de junio de 1993. Francia, Conseil Constitutionnel, Décision 93-320 DC du 21 juin 1993, Loi de finances rectificative 
Ahora bien, no hacen parte del bloque constitucional: los reglamentos de las asambleas; las normas internacionales y los principios generales del Derecho. Es dable resaltar — para tener claridad frente al caso colombiano - que el juez constitucional francés no ejerce un control "sobre la conformidad de las leyes a las normas del Derecho internacional general", y tampoco frente a los tratados particulares; así, rechazó en 1975 la posibilidad de controlar las leyes con respecto a los tratados internacionales ratificados por Francia $^{41}$. En cuanto a los principios generales en decisión [principe de valeur constitutionnelle] de $1979^{42}$, GEORGES VeDEL señaló que deben diferenciarse los principios invocados por las leyes de la República de los principios generales invocados en la jurisprudencia del Consejo de Estado francés. Para el Consejo Constitucional, no hay principios generales del derecho constitucional.

En cuanto a las leyes orgánicas, el Consejo Constitucional ha anulado la violación de las mismas por razones de competencia, es decir, el legislador ordinario debe respetar los límites que le

pour 1993, Journal Officiel, 23 juin 1993. Disponible en: http://www.conseil-constitutionnel.fr/ conseil-constitutionnel/francais/les-decisions/acces-par-date/decisions-depuis-1959/1993/93320-dc/decision-n-93-320-dc-du-21-juin-1993.10485.html. Las sentencias del tribunal pueden encontrarse en www.conseil-constitutionnel.fr. Ver al respecto: FrançoIs BARQuE, El principio de sinceridad presupuestaria en Francia: de la esperanza al desengaño, 95 Revista Española de Derecho Constitucional, 203-214 (mayo-agosto 2012). Disponible en: https://dialnet.unirioja.es/ descarga/articulo/4002085.pdf. También mediante la reforma constitucional realizada en 2008 se permite la excepción de inconstitucionalidad, esta reforma que entró en vigencia en 2010 permite a los tribunales, tanto civiles como contencioso-administrativos, remitir al Consejo Constitucional la cuestión de inconstitucionalidad de la ley en cuanto a los derechos y libertades que las normas del bloque han unificado, "siempre que la Corte de Casación o el Consejo de Estado, según el caso, autoricen tal reenvío prejudicial, pudiendo entonces el Consejo Constitucional decidir acerca de su derogación. Francia, Loi constitutionnelle 2008-724 du 23 juillet 2008, de modernisation des institutions de la $V^{\mathrm{e}}$ République, Journal Officiel, 24 juillet 2008. Disponible en: http://www.conseil-constitutionnel.fr/conseil-constitutionnel/francais/la-constitution/lesrevisions-constitutionnelles/loi-constitutionnelle-n-2008-724-du-23-juillet-2008.16312.html. Esto ha sido considerado una "revolución jurídica". Ver al respecto: Bernard Pacteau, Duguit ¡El Estado Reencontrado!, 185 Revista de Administración Pública, 345-363 (mayo-agosto 2011). Disponible en: https://dialnet.unirioja.es/descarga/articulo/3732694.pdf

41 Louis Favoreu \& Francisco Rubio-Llorente, Bloque de constitucionalidad (Derecho Constitucional), en Enciclopedia Jurídica Básica, t. 1, 35 (Civitas, Madrid, 1995). Francia, Conseil Constitutionnel, Décision 74-54 DC du 15 janvier 1975, Loi relative à l'interruption volontaire de la grossesse, Journal Officiel, 16 janvier 1975. Disponible en: http://www.conseil-constitutionnel.fr/conseil-constitutionnel/francais/les-decisions/1975/74-54-dc/decision-n-74-54-dcdu-15-janvier-1975.7423.html

42 Francia, Conseil Constitutionnel, Décision 79-105 DC du 25 juillet 1979, Loi modifiant les dispositions de la loi 74-696 du 7 août 1974 relatives à la continuité du service public de la radio et de la télévision en cas de cessation concertée du travail, Journal Officiel, 27 juillet 1979. Disponible en: http://www.conseil-constitutionnel.fr/conseil-con..decision-n-79-105-dcdu-25-juillet-1979.7724.html 
son impuestos por las leyes orgánicas por su contenido material, así como los límites procedimentales; su violación implicaría la trasgresión de la ley orgánica pero no de la Constitución (este caso es fundamental para diferenciar el caso español y el concepto lato sensu desarrollado en Colombia).

De lo expuesto, puede señalarse que la figura del bloque de constitucionalidad ha unificado y armonizado a partir de normas portadoras de derechos diferenciables históricamente, y de los principios contenidos en las leyes de la República y la Constitución de 1958. De esta manera, la Constitución francesa se complementa de acuerdo a las tendencias modernas de posguerras. Las normas que la integran hacen una unidad y la armonizan, constituyen un solo sentido en su conjunto ${ }^{43}$.

\section{A. Particularidad del concepto de bloque de constitucionalidad en un ordenamiento complejo, como el español}

Para comprender el bloque de constitucionalidad en un ordenamiento complejo, como el español, se hace necesario mencionar que en lo que hoy conocemos como España ha habido un contencioso histórico territorial, antes de la formación estatal y posterior a ella, que en el siglo XX dio vida al cuarto sentido del bloque de constitucionalidad en el marco de la Constitución de $1978^{44}$. En la península ibérica hubo una configuración casi federal entre los siglos XV y XVII ${ }^{45}$. Pero el proyecto centralizante de Castilla adquirió relevancia y se impuso con la rendición de Granada en

43 Louis Favoreu \& Francisco Rubio-Llorente, Bloque de constitucionalidad (Derecho Constitucional), en Enciclopedia Jurídica Básica, t. 1, 42 (Civitas, Madrid, 1995).

44 España, Constitución de 1978, 311 Boletín Oficial del Estado, BOE, 29 de diciembre de 1978. Disponible en: http://www.boe.es/diario_boe/txt.php?id=BOE-A-1978-31229

45 Daniel J. Elazar, Exploring Federalism, 755-756 (The University of Alabama Press, Tuscaloosa, London, 1991). Ignacio María Lojendio e Irure señala que "la raíz misma de la autonomía histórica de los países o pueblos españoles está en la idea de pacto. Soporte jurídico de nuestras viejas libertades, privilegios y franquezas". Los fueros respondían a esta concepción política medieval esencialmente pactista. Ignacio María Lojendio e IruRe, Autonomía y consenso, en Federalismo y regionalismo, 51-86, 66-67 (Gumersindo Trujillo, coordinación y presentación, Centro de Estudios Constitucionales, Madrid, 1979). En el mismo sentido, Luis Moreno-Fernández, La federalización de España. Poder político y territorio, 51 y ss. (Siglo XXI Editores, Madrid, 1997). Esta tesis también la desarrollé en VANESSA SueltCock, Federalismo en teoría y práctica - El caso español como proceso federal - Estudio de la autonomía regional y local en los sistemas federales (Juruá Editora, Curitiba, Brasil, 2010). 
1492. Esto dio lugar a un proceso de centralización, que eliminó progresivamente los elementos federales y que prevaleció hasta el siglo XIX ${ }^{46}$.

El proyecto centralizador de Castilla no logró borrar el pasado de los fueros locales y la libertad para gobernarse, es decir, los rasgos federales que estas estructuras presentaban ${ }^{47}$.

Algunas de las estructuras de gobierno local permanecieron hasta el siglo XIX. Esta situación y el nacimiento de los nacionalismos en ese mismo siglo realzaron la presencia de comunidades históricas que preceden la formación estatal e impiden la conformación del proyecto nacional español. Esta situación ha sido llamada el contencioso histórico territorial: la confrontación entre los nacionalismos periféricos con el proyecto nacional central de caracteres unitarios.

Tras la dictadura franquista [Francisco Franco, 1939-1975], uno de los objetivos de la Constitución de 1978 fue resolver el problema de la organización territorial del Estado: esa era una de las condiciones de la democracia. Se resolvió entonces reconocer la autonomía de las comunidades autónomas. Para ello se aprobó una ley orgánica que desarrolló las competencias dispuestas en la Constitución. Pasadas las leyes orgánicas, tres comunidades obtuvieron el más alto nivel de autonomía (País Vasco, Galicia y Cataluña ${ }^{48}$ y el resto una autonomía limitada, competencias que se igualaron en $1992^{49}$.

46 Daniel J. Elazar, Federal Systems of the World, A Handbook of Federal, Confederal and Autonomy Arrangements, 227 (Jerusalem Institute for Federal Studies, Longman Group, Harlow, Essex, United Kingdom, 1991). Ver también al respecto: Vanessa Suelt-Cock, Federalismo en teoría y práctica - El caso español como proceso federal - Estudio de la autonomía regional y local en los sistemas federales (Juruá Editora, Curitiba, Brasil, 2010).

47 Vanessa Suelt-Cock, Federalismo en teoría y práctica - El caso español como proceso federal - Estudio de la autonomía regional y local en los sistemas federales (Juruá Editora, Curitiba, Brasil, 2010).

48 España, Ley Orgánica 3/1979, de 18 de diciembre, de Estatuto de Autonomía para el País Vasco, 306 Boletín Oficial del Estado, BOE, 22 de diciembre de 1979. Disponible en: https:// www.boe.es/buscar/pdf/1979/BOE-A-1979-30177-consolidado.pdf, https://www.boe.es/boe/ dias/1979/12/22/pdfs/A29357-29363.pdf. España, Ley Orgánica 1/1981, de 6 de abril, de Estatuto de Autonomía para Galicia, 101 Boletín Oficial del Estado, BOE, 28 de abril de 1981. Disponible en: https://www.boe.es/buscar/doc.php?id=BOE-A-1981-9564. España, Ley Orgánica 4/1979, de 18 de diciembre, de Estatuto de Autonomía de Cataluña, 306 Boletín Oficial del Estado, BOE, 22 de diciembre de 1979. Disponible en: https://www.boe.es/diario_boe/txt.php?id=BOEA-1979-30178

49 España, Ley Orgánica 9/1992, de 6 de abril, de transferencia de competencias a Comunidades Autónomas que accedieron a la autonomía por la vía del artículo 143 de la Constitución, 308 Boletín Oficial del Estado, BOE, 24 de diciembre de 1992. Disponible en: https://www.boe.es/ buscar/doc.php?id=BOE-A-1992-28426 
Por consiguiente, la Constitución de 1978 estableció un diseño de reparto competencial entre el Estado y las CCAA, que solo se perfecciona con los Estatutos de Autonomía ${ }^{50}$; el carácter complementario de estas leyes orgánicas ha determinado su reconocimiento como "auténticas normas materialmente constitucionales", pues, "el sistema de distribución territorial del poder no es el resultado único de la Constitución, sino del juego conjunto de la norma suprema y de los Estatutos de Autonomía"51. Los Estatutos son entonces normas que - por expresa remisión constitucional - cumplen una función constitucional. Por esto, cabe considerarlos como normas constitucionales o de naturaleza constitucional, "en cuanto integran, junto con las disposiciones de la Constitución, un conjunto o bloque normativo denominado bloque de constitucionalidad"52.

Los Estatutos de Autonomía establecen las competencias de las Comunidades Autónomas. Se constituyen en el "principio decisorio para saber si una determinada competencia es o no de una Comunidad" 53 . Estas normas básicas de las CCAA deben ser interpretadas en el marco constitucional, obedeciendo con ello al principio de supremacía de la Constitución. Así, en conflictos entre las CCAA y el Estado en torno a la titularidad de una competencia, el Tribunal constitucional se ciñe en primera instancia a la Constitución y posteriormente al Estatuto correspondiente, lo que representa el bloque de constitucionalidad. "[E]1 Tribunal considerará además de los preceptos constitucionales, las Leyes

50 Francisco López-Ruiz, Los conceptos de 'todo' y 'parte' aplicado al estudio de los estados compuestos, 17 Revista Española de Derecho Constitucional, 49, 145-167, 150 (1997). Disponible en: https://dialnet.unirioja.es/descarga/articulo/79577.pdf

51 Rafael Bustos-Gisbert, Las tensiones del Estado autonómico ante el proceso de reforma estatutaria, Revista Jurídica de Castilla y León. Número Extraordinario: La Reforma de los Estatutos de Autonomía, 69-87, 73 (2004). Disponible en: http://www.jcyl.es/web/jcyl/binarios/674/623/ Estats09-R.Bustos.pdf?blobheader=application $\% 2$ Fpdf $\% 3$ Bcharset $\% 3$ DUTF-8. España, Tribunal Constitucional, Pleno, Sentencia 76/1983, STC 76/1983, 5 de agosto de 1983, 197 Boletín Oficial del Estado, BOE, 18 de agosto de 1983, fundamento jurídico 2. Disponible en: http://www.tribunalconstitucional.es/es/jurisprudencia/Paginas/Sentencia.aspx?cod=16830

52 Luis María LóPez-Guerra, La función constitucional y el contenido del Estatuto de Autonomía, en Estudios sobre la reforma del Estatuto, 12 (CARles Viver I Pi SunYer, ed., Generalitat de Catalunya, Institut d'Estudis Autonòmics, IEA, Barcelona, 2004).

53 Así lo sostuvo el Tribunal Constitucional, en sentencia 18/1991 fundamento jurídico 1, en Francisco Tomás y VAliente, El reparto competencial en la jurisprudencia del Tribunal Constitucional, 73 (Tecnos, Madrid, 1988). España, Tribunal Constitucional, Pleno, Sentencia 18/1991, STC 18/1991, 31 de enero de 1991, 48 Boletín Oficial del Estado, BOE, 25 de febrero de 1991. Disponible en: http://www.tribunalconstitucional.es/es/jurisprudencia/Paginas/Sentencia. aspx?cod $=18283$ 
que, dentro del marco constitucional, se hubieren dictado para delimitar las competencias del Estado y las diferentes Comunidades Autónomas", completando de este modo la interpretación en los casos de conflictos de competencias (STC 42/1983) ${ }^{54}$.

Este sentido del bloque de constitucionalidad en España permite comprender que los Estatutos de Autonomía tienen una posición jurídica que se asemeja a la de las Constituciones de los Estados miembros en un Estado Federal ${ }^{55}$. En el caso español, estos documentos concretan el cuadro competencial y ponen en marcha el proceso autonómico dispuesto constitucionalmente; guardan una especial rigidez (Art. 152.2 y 147.3 de la Constitución de 1978), que impide su modificación de forma unilateral por el Estado ${ }^{56}$, y se constituyen en las normas superiores de cada Comunidad Autónoma. Sin estas normas - como en los sistemas federales clásicos, respecto de las constituciones de los $\operatorname{estados}^{57}$-, no puede comprenderse la organización territorial de ese país.

En efecto, la organización territorial de España resulta del conjunto normativo integrado por la Constitución de 1978 y las 17 normas de carácter constitucional derivado o cuasiconstitu-

54 Francisco Tomás y VAliente, El reparto competencial en la jurisprudencia del Tribunal Constitucional, 73 (Tecnos, Madrid, 1988). España, Tribunal Constitucional, Pleno, Sentencia 42/1983, STC 42/1983, 20 de mayo de 1983, 144 Boletín Oficial del Estado, BOE, 17 de junio de 1983. Disponible en: http://www.tribunalconstitucional.es/es/jurisprudencia/Paginas/Sentencia. aspx?cod= 16796

55 Sobre el particular, IgNacio de OtTo y Pardo sostuvo que los procesos constituyentes y los de formación de estatutos se han aproximado notablemente. Ignacio de OtTo y PARdo, Estudios sobre derecho estatal y autonómico, 34 (Editorial Civitas, Madrid, 1986). En esta línea, JuAN José SolozÁbal-EchaVArRía señala que son normas cuasiconstitucionales. JuAN JosÉ Solozábal-Echavarría, El estado autonómico en perspectiva, 124 Revista de Estudios Políticos (Nueva Época), 9-28, 12 (abril-junio 2004). Disponible en: https://dialnet.unirioja.es/descarga/ articulo/968174.pdf. JOAQuín TORNos, La organización territorial del Estado español: el Estado de las Autonomías, en El federalismo en Europa, 143-166, 149 (Thomas Fleiner-Gerster, Dieter Grimm, Heinz Schäffer, Francis Delpérée \& Joaquín Tornos, Hacer, Barcelona, 1993). Mientras Francisco Rubio-Llorente señala que son normas constitucionales derivadas. Francisco Rubio-Llorente, La forma del poder. Estudio sobre la Constitución, 114-115 (Centro de Estudios Políticos y Constitucionales, Madrid, 1993).

56 La rigidez de los Estatutos (artículos 152.2 y 147.3 de la Constitución) y la elevación al bloque de constitucionalidad ha hecho que los Estatutos no puedan ser modificados por el poder legislativo del Estado. "Una ley Orgánica que pretendiese alterar su contenido estatutario, sería nula de pleno derecho". EdUARdo GarCía DE EnTERría, Sobre el modelo autonómico español y sobre las actuales tendencias federalistas, en La revisión del sistema de autonomías territoriales: reforma de estatutos, leyes de transferencia y delegación, federalismo (Civitas, Madrid, 1988). Texto disponible en: http://www.cuentayrazon.org/revista/pdf/030/Num030_002.pdf

57 John Kincaid, State Constitutions in the Federal System, 496 The Annals of The American Academy of Political and Social Science, AAAPSS, 12-22 (1988). 
cionales $^{58}$, pues configuran la organización territorial del Estado, dispuesta en líneas generales en la Carta política ${ }^{59}$. Esta integración es la que se denomina bloque de constitucionalidad y dota el sistema español de gran flexibilidad, en especial en la situación de pluralismo ordinamental. Los conflictos competenciales pueden ajustarse flexiblemente teniendo en cuenta la diversidad de normas infraconstitucionales que integran el parámetro de constitucionalidad.

El bloque no solo tiene una expresión frente a las normas que configuran la autonomía regional, sino que se ha extendido incluso a la configuración de la autonomía local. Esta extensión afecta el sistema de fuentes del derecho español. Es decir, una norma estatal o autonómica será valorada respecto de las competencias estatales en materia de organización territorial de carácter constitucional y luego de ello, será confrontada con los Estatutos de Autonomía. Al igual que en el caso francés, el caso español permite comprender una alteración de las fuentes del derecho incluyendo el ámbito constitucional las normas orgánicas que complementan la organización territorial del Estado posconstitucional, lo cual amplía el parámetro de control de constitucionalidad, con normas sin las cuales no puede comprenderse el diseño territorial de España.

Para finalizar, es relevante señalar que un sector de la doctrina considera que, tras 25 años de la Constitución española, también se presentaba un bloque de constitucionalidad procesal; así, ITZIAR Gómez-FERnÁnDEz ${ }^{60}$ indicaba que el Tribunal ha integrado al control directo de constitucionalidad otras normas diferentes a la estructura territorial del Estado. Esta autora sostiene esta premisa porque el resto de la Constitución española no se encuentra cerrada y en ese sentido, la doctrina ha señalado que se presenta un bloque de constitucional procesal. Al respecto, el artículo 28.2 de la Ley Orgánica 2/1979, LOTC ${ }^{61}$, señala que las leyes orgánicas

58 Diego López-Garrido, Marcos Francisco Massó-Garrote \& Lucio Pegoraro, dirs., El Estado Autonómico como variante del Estado compuesto, en Nuevo Derecho Constitucional Comparado, capítulo decimotercero, 565-672 (Tirant lo Blanch, Valencia, 2000).

59 Diego López-Garrido, Marcos Francisco Massó-Garrote \& Lucio Pegoraro, dirs., El Estado Autonómico como variante del Estado compuesto, en Nuevo Derecho Constitucional Comparado, capítulo decimotercero, 565-672 (Tirant lo Blanch, Valencia, 2000).

60 Itziar Gómez-Fernández, Redefinir el bloque de la constitucionalidad 25 años después, 54 Estudios de Deusto, 1, 61-98 (Bilbao, enero-junio 2006). Disponible en: http://revista-estudios. revistas.deusto.es/article/view/425/587

61 España, Ley Orgánica 2/1979, de 3 de octubre de 1979, del Tribunal Constitucional, LOTC, 239 Boletín Oficial del Estado, BOE, 5 de octubre de 1979. Disponible en: https://www.boe.es/ 
constituyen el parámetro de constitucionalidad directo de las leyes ordinarias de acuerdo con el artículo 81 de la Constitución española y "el artículo 73.1 LOTC alude a las leyes orgánicas que ordenan los órganos constitucionales completando, de este modo, que los dictados constitucionales se ajusten a la actuación de los órganos constitucionales, es decir, el Congreso, el Senado, el Gobierno y el Consejo General del Poder Judicial"62.

La función procesal del bloque de constitucionalidad lo define como "el conjunto de normas que, con independencia de que posean o no una función intrínseca de delimitación competencial, son utilizadas como parámetro de control por el Tribunal Constitucional que entiende que su infracción por otra norma determina la inconstitucionalidad de esta última, debido a que ocupan una determinada posición en el sistema de fuentes. Dicho de otro modo, las disposiciones normativas integrantes del bloque de constitucionalidad serían todas las normas de distinta naturaleza y rango normativo que, junto a la Constitución formal, sirven a los órganos tutelares del ordenamiento para verificar la constitucionalidad de las restantes normas del mismo"63, ya que, por sí mismas, determinan la invalidez de las normas de la legislación ordinaria que la contradigan. Ahora bien, respecto a la posibilidad de que un tratado internacional integre el parámetro de constitucionalidad el Tribunal ha señalado que no sirve como parámetro de constitucionalidad de las normas internas, $\mathrm{y}$, por lo tanto, no forma parte del bloque de constitucionalidad. Del mismo modo, el Derecho Comunitario de la Unión Europea tampoco hace parte del parámetro directo del control de constitucionalidad ${ }^{64}$.

buscar/act.php?id=BOE-A-1979-23709

62 Itziar Gómez-Fernández, Redefinir el bloque de la constitucionalidad 25 años después, 54 Estudios de Deusto, 1, 61-98, 74 (Bilbao, enero-junio 2006). Disponible en: http://revista-estudios. revistas.deusto.es/article/view/425/587

63 Itziar Gómez-Fernández, Redefinir el bloque de la constitucionalidad 25 años después, 54 Estudios de Deusto, 1, 61-98, 82 (Bilbao, enero-junio 2006). Disponible en: http://revista-estudios. revistas.deusto.es/article/view/425/587

64 Sentencias del Tribunal Constitucional: España, Tribunal Constitucional, Pleno, Sentencia 128/1999, STC 128/1999, 1 de julio de 1999, 181 Boletín Oficial del Estado, BOE, 30 de julio de 1999. Disponible en: http://hj.tribunalconstitucional.es/es/Resolucion/Show/3870. España, Tribunal Constitucional, Pleno, Sentencia 208/1999, STC 208/1999, 11 de noviembre de 1999, 300 Boletín Oficial del Estado, BOE, 16 de diciembre de 1999. Disponible en: http:// hj.tribunalconstitucional.es/es/Resolucion/Show/3950. España, Tribunal Constitucional, Pleno, Sentencia 45/2001, STC 45/2001, 15 de febrero de 2001, 65 Boletín Oficial del Estado, BOE, 16 de marzo de 2001. Disponible en: http://www.tribunalconstitucional.es/es/jurisprudencia/ 


\section{EL BLOQUE DE CONSTITUCIONALIDAD EN COLOMBIA}

Para comprender la figura del bloque en Colombia es necesario contextualizar que el discurso de los derechos humanos comienza a influenciar las constituciones en América Latina a partir de la década de 1970, en parte, por la presión política del presidente de Estados Unidos, Jimmy Carter [1977-1981], quien reconociendo los excesos de la Guerra Fría con el apoyo de dictaduras en la América Latina comenzó un movimiento para la firma de la Convención Americana de Derechos Humanos, promulgada en San José de Costa Rica el 22 de noviembre de 1969, y asignó recursos para el funcionamiento de la Comisión Interamericana de Derechos Humanos, CIDH. JoRge GONZÁLEZ-JÁcOME sostiene que con anterioridad en 1959, la Organización de Estados Americanos, OEA, la Quinta Reunión de Consulta de Ministros de Relaciones Exteriores, en Santiago de Chile, había creado la Comisión de Derechos Humanos; no obstante, solo en la década del 70 comenzó a presionarse a los estados que vulneraban los derechos humanos. "Antes de esta época los derechos humanos eran considerados unas premisas morales que no producían consecuencias jurídicas" ${ }^{95}$. A finales de la década del 70 en Colombia, al igual que en otros países en América Latina había "altos niveles de represión gubernamental” con la comisión de torturas y desapariciones por parte de agentes oficiales a sectores de izquierda y la realización de juicios a civiles por parte de militares que vulneraban el derecho al debido proceso $^{66}$.

El informe del Centro Nacional de Memoria Histórica en Colombia señala que antes de 1987 las relaciones entre guerra y justicia estaban enmarcadas en un contexto de excepcionalidad en el tratamiento del orden público. Se delegaban a la justicia

Paginas/Sentencia.aspx?cod=18283. España, Tribunal Constitucional, Pleno, Sentencia 38/2002, STC 38/2002, 14 de febrero de 2002, 63 Boletín Oficial del Estado, BOE, 14 de marzo de 2002. Disponible en: http://hj.tribunalconstitucional.es/es/Resolucion/Show/4574

65 Jorge González-Jácome, Estados de excepción democracia liberal en América del Sur: Argentina, Chile y Colombia (1930-1990), 239 (Pontificia Universidad Javeriana, Bogotá, 2015).

66 Colombia, Centro Nacional de Memoria Histórica, ;Basta ya! Colombia: Memorias de guerra y dignidad, Capítulo 3, Guerra y justicia en la sociedad colombiana, 200 y ss. (Centro Nacional de Memoria Histórica, Imprenta Nacional, Bogotá, 2013). Disponible en: http://www.centrodememoria historica.gov.co/micrositios/informeGeneral/descargas.html, http://centrodememoria historica.gov.co/descargas/informes2013/bastaYa/capitulos/basta-ya-cap3_196-257.pdf 
militar los casos que amenazaban el orden y la seguridad pública. Esas relaciones se regían por el Código de Justicia Penal Militar ${ }^{67}$ y reformas de la jurisdicción penal cuya influencia residía en la doctrina de Seguridad Nacional basada en la idea de enfrentar a la insurgencia mediante la fuerza militar en el contexto de Guerra Fría. En América Latina en la década del 70, los consejos de guerra juzgaban a los opositores políticos de carácter civil ${ }^{68}$. Esto generó una crisis en la situación de derechos humanos por las vulneraciones que se cometían con base en el Estatuto de Seguridad ${ }^{69}$, decreto que criminalizaba la protesta social y los movimientos sociales fueron asimilados a la subversión.

Entre 1949 y 1991 Colombia estuvo más de 30 años bajo estado de sitio. En los 21 años transcurridos entre 1970 y 1991 Colombia vivió 206 meses bajo estado de excepción, es decir, 17 años, lo cual representa el 82\% del tiempo transcurrido. El hecho de que la excepcionalidad se convirtiera en la regla durante este periodo tuvo impactos muy negativos sobre la justicia, el Estado de derecho y la democracia. En primer lugar, porque implicó la pérdida de muchas vidas y masivas vulneraciones a los Derechos Humanos por el recorte permanente de las garantías constitucionales y las libertades públicas ${ }^{70}$.

A finales de la década de 1970, la aparición del narcotráfico agregó nuevas variables a la violencia y al conflicto armado. La guerra contra las drogas, política exterior de los gobiernos de Estados Unidos, acogía el discurso de atacar la producción de droga desde un enfoque militar, así muchos temas que pudieron ser materia de normas de policía tuvieron soluciones drásticas en las dialécticas

67 Colombia, Decreto 250 de 1958, 11 de julio de 1958, por el cual se expide el Código de Justicia Penal Militar, 29.824 Diario Oficial, 25 de noviembre de 1958. Disponible en: http://www. suin-juriscol.gov.co/viewDocument.asp?id=1711708

68 Colombia, Centro Nacional de Memoria Histórica, ;Basta ya! Colombia: Memorias de guerra y dignidad, Capítulo 3, Guerra y justicia en la sociedad colombiana, 201 (Centro Nacional de Memoria Histórica, Imprenta Nacional, Bogotá, 2013). Disponible en: http://www.centrodememoriahistorica.gov.co/micrositios/informeGeneral/descargas.html, http://centrodememoriahistorica.gov.co/descargas/informes2013/bastaYa/capitulos/basta-ya-cap3_196-257.pdf

69 Colombia, Decreto 1923 de 1978, por el cual se dictan normas para la protección de la vida, honra y bienes de las personas y se garantiza la seguridad de los asociados, 35.101 Diario Oficial, 21 de septiembre de 1978. Disponible en: https://www.minjusticia.gov.co/portals/0/ MJD/docs/decreto_1923_1978.htm

70 Colombia, Centro Nacional de Memoria Histórica, ¡Basta ya! Colombia: Memorias de guerra y dignidad, Capítulo 3, Guerra y justicia en la sociedad colombiana, 201-202 (Centro Nacional de Memoria Histórica, Imprenta Nacional, Bogotá, 2013). Disponible en: http://www.centrodememoria historica.gov.co/micrositios/informeGeneral/descargas.html, http://centrodememoria historica.gov.co/descargas/informes2013/bastaYa/capitulos/basta-ya-cap3_196-257.pdf 
de confrontación y enemigo. La organización militar adquiere relevancia en el Estado, y "un tratamiento bélico de problemas sociales que admitirían otro tipo de soluciones menos lesivas para la garantía de los derechos" $"$.

En este escenario, la Constitución de 1991 buscó una renovación de las prácticas políticas y la posibilidad de sentar las bases para que la paz fuera posible. En particular, la nueva Corte Constitucional, creada con esta Constitución, afrontó la necesidad de interpretar el texto constitucional, proteger y salvaguardar los derechos fundamentales, sociales, económicos, ambientales y colectivos. En este sentido, la justicia constitucional es protagónica en los últimos veinticinco años de la vigencia de la Constitución, sobresaliendo, la figura del bloque de constitucionalidad, como herramienta interpretativa mediante la cual la Corte amplía el parámetro de control para garantizar la coherencia del orden jurídico con los tratados internacionales, así como la tutela de derechos para lograr la salvaguarda de estos. El bloque permite una comprensión ampliada de los derechos consagrados en tratados internacionales ratificados por Colombia, y significa culturalmente un cambio de perspectiva del Estado frente a su atención y respeto, frente a un contexto de violación de derechos que marcó la historia constitucional colombiana del siglo $\mathrm{XX}$.

De acuerdo con lo anterior, la figura del bloque de constitucionalidad en Colombia se introdujo con la sentencia C-225-9572,

71 Colombia, Centro Nacional de Memoria Histórica, ;Basta ya! Colombia: Memorias de guerra y dignidad, Capítulo 3, Guerra y justicia en la sociedad colombiana, 225 (Centro Nacional de Memoria Histórica, Imprenta Nacional, Bogotá, 2013). Disponible en: http://www.centrodememoria historica.gov.co/micrositios/informeGeneral/descargas.html,

72 En esta sentencia, la Corte revisó la constitucionalidad del Protocolo adicional a los Convenios de Ginebra del 12 de agosto de 1949, relativo a la protección de las víctimas de los conflictos armados sin carácter internacional (Protocolo II) hecho en Ginebra el 8 de junio de 1977, y de la Ley 171 del 16 de diciembre de 1994, por medio de la cual se aprueba dicho Protocolo. Corte Constitucional, Sentencia C-225-95, 18 de mayo de 1995, magistrado ponente Alejandro Martínez-Caballero. Disponible en: http://corteconstitucional.gov.co/relatoria/1995/c-225-95. htm. A pesar del pronunciamiento expreso que hace la Corte Constitucional del concepto de bloque en esta sentencia, autores como RODRIGO UPRIMNY-YEPES sostienen que la idea del bloque fue contemplada en las primeras sentencias de la Corte Constitucional, entre ellas, sentencia T-426-92 en la que la "Corte Constitucional tuvo en cuenta la Declaración de Derechos Humanos y el Pacto de Derechos Económicos Sociales y Culturales para reconocer como fundamental un derecho que no aparecía de manera expresa en la Carta: el derecho al mínimo vital”. Con ello se admitía la existencia de derechos y principios de valor constitucional y supraconstitucional. RoDrigo UPRIMNY-YePES, El bloque de constitucionalidad en Colombia. Un análisis jurisprudencial y un ensayo de sistematización doctrinal, Curso de formación de promotores/ as en derechos humanos, libertad sindical y trabajo decente (Universidad Nacional, Escuela 
que resolvió un problema de interpretación entre el principio de supremacía constitucional, contemplado en el artículo 4 de la Constitución, y el de prevalencia de ciertos tratados de derechos humanos ratificados por Colombia establecido en el artículo 93.

Para llegar a este concepto, la Corte se preguntó cuál era la prevalencia de los tratados de derecho internacional humanitario y cómo armonizar estos dos artículos para imponer su respeto a las normas de inferior jerarquía. Al respecto, señala, que para dar prevalencia a los tratados de derechos humanos y de derecho internacional humanitario contemplados en el artículo 93 y 214 numeral 2, debe comprenderse que "estos forman con el resto del texto constitucional un 'bloque de constitucionalidad', cuyo respeto se impone a la ley. En efecto, de esa manera se armoniza plenamente el principio de supremacía de la Constitución, como norma de normas (Constitución Política, artículo 4), con la prevalencia de los tratados ratificados por Colombia, que reconocen los derechos humanos y prohíben su limitación en los estados de excepción (Constitución Política, artículo 93)"73.

En este sentido, la Corte Constitucional señaló que la Constitución permite la interpretación que da vida al bloque de Constitucionalidad, por la importancia que da a ciertos instrumentos internacionales como se establece en los artículos 53, 93, 94 y 214, puesto que estos artículos establecen la importancia y preeminencia de los tratados internacionales ${ }^{74}$. Estas remisiones normativas permiten la interpretación de la existencia del concepto del bloque, lo que conduce a la invalidez de la norma si contradice sus contenidos. Así, en la sentencia C-578-95, la Corte señala que "es importante precisar que siempre que se habla de bloque de constitucionalidad,

Nacional Sindical, ENS Colombia, Bogotá, 2005). Disponible en: http://redescuelascsa.com/ sitio/repo/DJS-Bloque_Constitucionalidad(Uprimny).pdf. Corte Constitucional, Sentencia T-426-92, 24 de junio de 1992, magistrado ponente Eduardo Cifuentes-Muñoz. Disponible en: http://corteconstitucional.gov.co/relatoria/1992/t-426-92.htm

73 En sentencia anterior, Sentencia C-295-93, la Corte había señalado cuándo se presentaba la prevalencia así: "para que tenga lugar la prevalencia o superioridad de los tratados y convenios internacionales en el orden interno, es necesario que se den los dos supuestos a la vez, de una parte, el reconocimiento de un derecho humano, y de la otra que sea de aquellos cuya limitación se prohíba durante los estados de excepción". Corte Constitucional, Sentencia C-295-93, 29 de julio de 1993, magistrado ponente Carlos Gaviria-Díaz. Disponible en: http:// corteconstitucional.gov.co/relatoria/1993/c-295-93.htm

74 Corte Constitucional, Sentencia C-578-95, 4 de diciembre de 1995, magistrado ponente Eduardo Cifuentes-Muñoz, Fundamento Jurídico 3. Disponible en: http://corteconstitucional.gov.co/ relatoria/1995/c-578-95.htm 
se hace porque en la Constitución una norma suya así lo ordena y exige su integración, de suerte que la violación de cualquier norma que lo conforma se resuelve en últimas en una violación del Estatuto Superior" 75 .

El bloque definido en la sentencia C-225-95 está compuesto por "aquellas normas y principios que, sin aparecer formalmente en el articulado del texto constitucional, son utilizados como parámetro del control de constitucionalidad de las leyes, por cuanto han sido normativamente integrados a la Constitución por diversas vías y por mandato de la propia Constitución" 76 . De este modo, la Corte Constitucional introduce un concepto ideado por la doctrina francesa, gracias a la remisión normativa, pero cuyo contenido será variable, al estar supeditado a la definición jurisprudencial, y cuyas consecuencias en el ordenamiento jurídico serán la inconstitucionalidad de la norma, si contradice los contenidos del bloque.

Así, para conocer y evaluar las normas que integran el bloque de constitucionalidad por contraste con los sistemas europeos que se comparan, en este artículo se revisarán las sentencias que dan cuenta de este contenido y alguna doctrina que ha sistematizado esos pronunciamientos en materia de derechos. De este modo, se puede apreciar cómo hasta el año 2000, la Corte amplía el parámetro de control de constitucionalidad para proteger derechos, y a continuación lo limita aclarando que determinados instrumentos y jurisprudencia no comprenderán el bloque, sino que estos instrumentos podrán ser fuente auxiliar para el intérprete constitucional. En este recorrido temporal se aprecian las contradicciones jurisprudenciales de la Corte al determinar qué instrumentos componen el Bloque y que no lo hace.

75 Corte Constitucional, Sentencia C-578-95, 4 de diciembre de 1995, magistrado ponente Eduardo Cifuentes-Muñoz, fundamento jurídico 3. Disponible en: http://corteconstitucional.gov.co/ relatoria/1995/c-578-95.htm

76 Corte Constitucional, Sentencia C-225-95, 18 de mayo de 1995, magistrado ponente Alejandro Martínez-Caballero, fundamento jurídico 12. Disponible en: http://corteconstitucional.gov. co/relatoria/1995/c-225-95.htm 


\section{B. Configuración del Bloque Constitucional y contenidos}

Durante los primeros diez años de vida del bloque se destaca la aparición de los sentidos stricto y lato sensu. Estos sentidos permiten comprender la diversa naturaleza jurídica de las normas que contiene el bloque. Así, el primer estudio doctrinal que da cuenta del concepto y los contenidos fue realizado por el profesor RoDRIGo UPRIMNY ${ }^{77}$, quien en el año 2000, tras el estudio de toda la jurisprudencia pertinente, dio cuenta de los instrumentos que hasta ese momento componían este concepto ${ }^{78}$ teniendo en cuenta los dos sentidos desarrollados por la Corte.

Stricto sensu, por el cual "se ha considerado que se encuentra conformado por aquellos principios y normas de valor constitucional, los que se reducen al texto de la Constitución propiamente dicha y a los tratados internacionales que consagren derechos humanos cuya limitación se encuentre prohibida durante los estados de excepción (Constitución Política, artículo 93)"79. Entre los instrumentos que lo componen están:

Los tratados de límites ratificados por Colombia que reconocen derechos intangibles ${ }^{80}$; los artículos de los tratados de derechos humanos ratificados por Colombia cuando se trate de derechos re-

77 Rodrigo Uprimny-YePes, El bloque de constitucionalidad en Colombia. Un análisis jurisprudencial y un ensayo de sistematización doctrinal, Curso de formación de promotores/as en derechos humanos, libertad sindical y trabajo decente (Universidad Nacional, Escuela Nacional Sindical, ENS Colombia, Bogotá, 2005). Disponible en: http://redescuelascsa.com/sitio/repo/ DJS-Bloque_Constitucionalidad(Uprimny).pdf

78 Es importante señalar - como lo ha señalado el autor-que al no haber en Colombia compilaciones comentadas de jurisprudencias no hay un seguimiento, como el que debería, del pronunciamiento de la Corte. La determinación de lo que compone el bloque y no lo hace presenta problemas similares respecto del precedente y su funcionamiento, dado que la jurisprudencia no es conocida por toda la rama judicial, y tampoco se sabe cuáles de ellas son obligatorias. Entre otros autores que han señalado esta dificultad están CARLOS IGNACIO JARAMILlo-JARAMILlo, Hacia una jurisprudencia racional. Y relativamente vinculante. Observaciones y reparos al 'precedente obligatorio', en El precedente judicial en Colombia: papel y valor asignados a la jurisprudencia (JAVIER TAMAYO-JARAMILlo \& CARLOS IGNACIO JARAMILLOJaramillo, Ibáñez, Pontificia Universidad Javeriana, Bogotá, 2012).

79 Corte Constitucional, Sentencia C-191-98, 6 de mayo de 1998, magistrado ponente Eduardo Cifuentes-Muñoz. Disponible en: http://corteconstitucional.gov.co/relatoria/1998/c-191-98.htm

80 Corte Constitucional, Sentencia C-400-98, 10 de agosto de 1998, magistrado ponente Alejandro Martínez-Caballero. Disponible en: http://corteconstitucional.gov.co/relatoria/1998/c-400-98.htm 
conocidos por la Carta ${ }^{81}$. Los instrumentos de $\mathrm{DIH}^{82}$, instrumentos que se aplican aún en situaciones de grave anormalidad. Algunos convenios de la $\mathrm{OIT}^{83}$. La doctrina elaborada por los tribunales internacionales en relación con esas normas internacionales. Los pronunciamientos de los organismos de control de la OIT.

En sentido lato, comprende "aquellas normas, de diversa jerarquía, que sirven como parámetro para llevar a cabo el control de constitucionalidad de la legislación. Conforme a esta acepción, el bloque de constitucionalidad estaría conformado no solo por el articulado de la Constitución sino, entre otros, por los tratados

81 Ver investigación de Luis Andrés FAJARdo-Arturo, que cita los siguientes instrumentos internacionales y la jurisprudencia que los integra al bloque de constitucionalidad: "Convenios de Ginebra y Protocolo II sobre DIH (C.C., C 574/92) Convención Americana de Derechos Humanos, (C.C., T 260/99); Pacto Internacional de Derechos Sociales, Económicos y Culturales y el Protocolo adicional de San Salvador, sobre derechos económicos, sociales y culturales (C.C., C 251/97). Pacto Internacional de Derechos Civiles y Políticos (C.C., T-256/00); Instrumentos de Protección de los Derechos de los niños (C.C., C-1068/02). En la C-1068 de 2002 se establece que los tratados internacionales que traten sobre los derechos de los niños y que hayan sido ratificados por Colombia hacen parte del Bloque de Constitucionalidad. Entre estos se encuentran: Declaración de Ginebra de 1924 sobre los Derechos del Niño, Declaración de los Derechos del Niño adoptada por la Asamblea General de las Naciones Unidas el 20 de noviembre de 1959, y reconocida en la Declaración Universal de Derechos Humanos, el Pacto internacional de Derechos Civiles y Políticos (en particular, en los artículos 23 y 24)". LuIS Andrés Fajardo-Arturo, Contenido y alcance jurisprudencial del bloque de constitucionalidad en Colombia, 7 Civilizar, Ciencias Sociales y Humanas, 13, 15-34, 22 (julio-diciembre de 2007). Disponible en: http://repository.usergioarboleda.edu.co/bitstream/handle/11232/352/ CienciasSocialesyHumanas7133.pdf; jsessionid=6F155E70FDCEAD4A48B39639344BC68D? sequence $=1$

82 Corte Constitucional, Sentencia T-409-92, 8 de junio de 1992, magistrados ponentes Alejandro Martínez Caballero, Fabio Morón Díaz. Disponible en: http://www.corteconstitucional.gov. co/relatoria/1992/t-409-92.htm. Corte Constitucional, Sentencia C-574-92, 28 de octubre de 1992, magistrado ponente Ciro Angarita-Barón. Disponible en: http://corteconstitucional. gov.co/relatoria/1992/C-574-92.htm

83 Ver al respecto, sentencias de la Corte Constitucional: Corte Constitucional, Sentencia C-01000, 19 de enero de 2000, magistrado ponente Alejandro Martínez-Caballero. Disponible en: http://www.corteconstitucional.gov.co/relatoria/2000/c-010-00.htm. Corte Constitucional, Sentencia C-349-09, 20 de mayo de 2009, magistrado ponente Luis Ernesto Vargas-Silva. Disponible en: http://www.corteconstitucional.gov.co/relatoria/2009/c-349-09.htm. La sentencia C-349-09 señala en su consideración 4.2: "Los convenios que hacen parte del bloque de constitucionalidad en sentido estricto prevalecen en el orden interno, en cuanto prohíben la limitación de un derecho humano bajo los estados de excepción y en consecuencia hacen parte del parámetro de control constitucional de las normas legales que regulan la materia. Los convenios que forman parte del bloque de constitucionalidad en sentido lato sirven como referente para interpretar los derechos de los trabajadores y darle plena efectividad al principio fundamental de la protección del trabajador (Constitución Política, artículo 1) y al derecho al trabajo (Constitución Política, artículos 25 y 53)”. 
internacionales de que trata el artículo 93 de la Carta, por las leyes orgánicas $^{84} \mathrm{y}$, en algunas ocasiones, por las leyes estatutarias" ${ }^{85}$.

Ahora bien, para que un instrumento integre el bloque stricto sensu debe tratarse de instrumentos que consagren un derecho humano, por una parte, y por otra, debe tratarse de derechos humanos que no puedan limitarse en estados de excepción ${ }^{86}$. Así el profesor AlEJANDRo R AMELli ha señalado: "En primer lugar, en lo concerniente a las normas convencionales, el juez constitucional ha sido enfático en exigir que estas deben reconocer un derecho humano, con lo cual, prima facie, estaríamos ante un elenco bastante generoso y variopinto de tratados internacionales, de carácter universal (por ejemplo, Pacto Internacional de Derechos Civiles y Políticos; Pacto Internacional de Derechos Económicos, Sociales y Culturales; Convención contra la Tortura de 1984, etcétera) y regional (Pacto de San José de Costa Rica, Protocolo de San Salvador,

84 "Las leyes orgánicas se constituyen en reglamentos que establecen límites procedimentales, para el ejercicio de la actividad legislativa, en el caso de las leyes ordinarias en general y en el de ciertas y determinadas leyes en especial; son normas de autoreferencia [sic] para quienes tienen la facultad de expedirlas y posteriormente desarrollar la materia de la cual tratan, a través de leyes ordinarias. Son normas intermedias entre las disposiciones del ordenamiento superior y las normas que desarrollan la materia que ellas regulan; sin embargo, ellas no se 'incorporan al bloque de constitucionalidad', sino en los precisos casos en los que la misma Constitución lo disponga como requisito de trámite de las leyes". Corte Constitucional, Sentencia C-423-95, 21 de septiembre de 1995, magistrado ponente Fabio Morón-Díaz. Disponible en: http://corteconstitucional.gov.co/relatoria/1995/c-423-95.htm

85 Sentencias C-135-96, C-191-98 y C-582-99. Corte Constitucional, Sentencia C-135-96, 9 de abril de 1996, magistrados ponentes Jorge Arango-Mejía, Eduardo Cifuentes-Muñoz, Alejandro Martínez-Caballero. Disponible en: http://corteconstitucional.gov.co/relatoria/1996/c-135-96. $\mathrm{htm}$. La Corte Constitucional señala "por concepto de bloque de constitucionalidad en sentido lato se entiende: "aquellas normas que pertenezcan al denominado bloque de constitucionalidad lato sensu, se caracterizan por: (1) ser parámetro para efectuar el control de constitucionalidad del derecho interno; (2) tener un rango normativo superior a las leyes ordinarias (en algunos casos son normas constitucionales propiamente dichas y, en otros casos, ostentan una jerarquía intermedia entre la Constitución y la ley ordinaria); y, (3) formar [sic] parte del bloque de constitucionalidad gracias a una remisión expresa efectuada por alguna disposición constitucional". Corte Constitucional, Sentencia C-191-98, 6 de mayo de 1998, magistrado ponente Eduardo Cifuentes-Muñoz. Disponible en: http://corteconstitucional. gov.co/relatoria/1998/c-191-98.htm. Corte Constitucional, Sentencia C-582-99, 11 de agosto de 1999, magistrado ponente Alejandro Martínez-Caballero. Disponible en: http://www. corteconstitucional.gov.co/relatoria/1999/c-582-99.htm

86 Corte Constitucional, Sentencia C-191-98, 6 de mayo de 1998, magistrado ponente Eduardo Cifuentes-Muñoz. Disponible en: http://corteconstitucional.gov.co/relatoria/1998/c-191-98. htm, reiterada en Corte Constitucional, Sentencia C-582-99, 11 de agosto de 1999, magistrado ponente Alejandro Martínez-Caballero. Disponible en: http://www.corteconstitucional.gov. co/relatoria/1999/c-582-99.htm 
etcétera)"87 88 . También mencionan el Preámbulo de la Convención sobre los Derechos del Niño ${ }^{89}$.

Además del control abstracto de constitucionalidad y de la integración de los tratados internacionales de derechos humanos y del derecho internacional humanitario, es importante señalar que en Colombia el bloque de constitucionalidad lo integran - como señala Mónica Arango-Olaya - los derechos: a la vida y a la integridad personal; el derecho a no ser sometido a desaparición forzada, a torturas, ni a tratos o penas crueles, inhumanos o degradantes; el derecho al reconocimiento de la personalidad jurídica; la prohibición de la esclavitud, la servidumbre y la trata de seres humanos; la prohibición de las penas de destierro, prisión perpetua y confiscación; la libertad de conciencia; la libertad de religión; el principio de legalidad, de favorabilidad y de irretroactividad de la ley penal; el derecho a elegir y ser elegido; el derecho a contraer matrimonio y a la protección de la familia; los derechos del niño, a la protección por parte de su familia, de la sociedad y del Estado; el derecho a no ser condenado a prisión por deudas civiles; el derecho al Habeas Corpus y el derecho de los colombianos por nacimiento a no ser extraditados. Tampoco pueden ser suspendidas las garantías judiciales indispensables para la protección de tales derechos ${ }^{90}$.

Respecto de los principios que hacen parte del bloque de constitucionalidad estarían: el principio pro homine ${ }^{91}$, el pacta sunt servanda ${ }^{92}$; el principio de buena fe; el principio ius cogens las nor-

87 Alejandro Ramelli, Sistema de fuentes del derecho internacional público y 'bloque de constitucionalidad' en Colombia, 11 Cuestiones Constitucionales, 157-175, 160 (julio-diciembre de 2004). Disponible en http://www.redalyc.org/articulo.oa?id=88501105

88 Corte Constitucional, Sentencia C-191-98, 6 de mayo de 1998, magistrado ponente Eduardo Cifuentes-Muñoz. Disponible en: http://corteconstitucional.gov.co/relatoria/1998/c-191-98.htm

89 Corte Constitucional, Sentencia C-067-03, 4 de febrero de 2003, magistrado ponente Marco Gerardo Monroy-Cabra. Disponible en: http://www.corteconstitucional.gov.co/ relatoria/2003/c-067-03.htm

90 Mónica Arango-Olaya, El bloque de constitucionalidad en la jurisprudencia de la Corte Constitucional colombiana, 2004 Precedente, Revista Jurídica, 79-102, 82-83 (2004). Disponible en: http://www.icesi.edu.co/contenido/pdfs/C1C-marango-bloque.pdf

91 Corte Constitucional, Sentencia C-177-01, 14 de febrero de 2001, magistrado ponente Fabio Morón-Díaz. Disponible en: http://www.corteconstitucional.gov.co/relatoria/2001/c-177-01.htm. Corte Constitucional, Sentencia C-148-05, 22 de febrero de 2005, magistrado ponente Álvaro Tafur-Galvis. Disponible en: http://www.corteconstitucional.gov.co/relatoria/2005/c-148-05. htm. Corte Constitucional, Sentencia C-438-13, 10 de julio de 2013, magistrado ponente Alberto Rojas-Ríos. Disponible en: http://www.corteconstitucional.gov.co/relatoria/2013/c-438-13.htm

92 Corte Constitucional, Sentencia C-400-98, 10 de agosto de 1998, magistrado ponente Alejandro Martínez-Caballero. Disponible en: http://corteconstitucional.gov.co/relatoria/1998/c-400-98.htm 
mas que integran el orden público internacional ${ }^{93}$. Ejemplos del ius cogens son la prohibición de actos de agresión y el genocidio. El Sistema Interamericano de protección de la vida de los niños y niñas, artículo 27 de la Convención Interamericana de Derechos Humanos y el artículo 4 numeral 2 del Pacto Internacional de Derechos Civiles y Políticos.

Con posterioridad a la sentencia C-358-97 en la que la Corte definió qué comprendía por stricto y lato sensu del bloque, la sentencia C-708-9994 excluyó del sentido lato la ley estatutaria de administración de justicia del bloque de constitucionalidad por no haber remisión expresa de la Carta. A diferencia de la ley estatutaria de estados de excepción que sí tiene remisión expresa en la Carta en el artículo 214.

Frente al bloque stricto sensu en la sentencia C-582-9995, la Corte sostuvo que podía ampliarse el concepto a los Tratados de límites y extender los derechos a algunos Convenios de la OIT que consagran derechos que no pueden ser suspendidos en estados de excepción. En sentencia T-568-9996 incluyó las recomendaciones de la Comisión Interamericana de Derechos Humanos ${ }^{97}$ y las recomendaciones del Comité de Libertad Sindical de la Organización Internacional del Trabajo, OIT ${ }^{98}$, cuando estas han sido avaladas por el Consejo

93 Corte Constitucional, Sentencia C-027-93, 5 de febrero de 1993, magistrado ponente Simón Rodríguez-Rodríguez. Disponible en: http://corteconstitucional.gov.co/relatoria/1993/c-027-93. $\mathrm{htm}$. Corte Constitucional, Sentencia C-240-09, 1 de abril de 2009, magistrado ponente Mauricio González-Cuervo. Disponible en: http://www.corteconstitucional.gov.co/ relatoria/2009/c-240-09.htm. Corte Constitucional, Sentencia C-249-12, 29 de marzo de 2012, magistrado ponente Juan Carlos Henao-Pérez. Disponible en: http://www.corteconstitucional. gov.co/relatoria/2012/c-249-12.htm. Corte Constitucional, Sentencia SU-195-98, 7 de mayo de 1998, magistrado ponente Vladimiro Naranjo-Mesa. Disponible en: http://corteconstitucional. gov.co/relatoria/1998/su195-98.htm

94 Corte Constitucional, Sentencia C-708-99, 22 de septiembre de 1999, magistrado ponente Álvaro Tafur-Galvis. Disponible en: http://www.corteconstitucional.gov.co/relatoria/1999/c-708-99.htm

95 Corte Constitucional, Sentencia C-582-99, 11 de agosto de 1999, magistrado ponente Alejandro Martínez-Caballero. Disponible en: http://www.corteconstitucional.gov.co/ relatoria/1999/c-582-99.htm

96 Corte Constitucional, Sentencia T-568-99, 10 de agosto de 1999, magistrado ponente Carlos Gaviria-Díaz. Disponible en: http://www.corteconstitucional.gov.co/relatoria/1999/t-568-99.htm

97 Organización de Estados Americanos, OEA, Corte Interamericana de Derechos Humanos, CorteIDH, Ciertas atribuciones de la Comisión Interamericana de Derechos Humanos, Opinión Consultiva OC-13/93, 16 de julio de 1993, Serie A 13. Disponible en: http://www. corteidh.or.cr/docs/opiniones/seriea_13_esp.pdf. Organización de Estados Americanos, OEA, Corte Interamericana de Derechos Humanos, CorteIDH, Responsabilidad internacional por expedición y aplicación de leyes violatorias de la Convención, Opinión Consultiva OC-14/94, 9 de diciembre de 1994, Serie A 14. Disponible en: http://hrlibrary.umn.edu/iachr/!oc-14.pdf

98 Organización Internacional del Trabajo, OIT, Comité de Libertad Sindical, Informe provi- 
de Administración. Mientras en la sentencia C-010-00 la Corte reconoce que la jurisprudencia de las instancias internacionales de derechos humanos es un criterio relevante hermenéutico para interpretar derechos humanos ${ }^{99}$.

En suma, hasta el año 2000 puede comprenderse que el bloque de constitucionalidad está compuesto por un conjunto normativo que está fuera del texto constitucional, pero que por remisión constitucional y desarrollo jurisprudencial integran el parámetro de constitucionalidad. Dentro del bloque, stricto sensu, la Corte Constitucional incluyó diversas tipologías de normas, como: el preámbulo de la Constitución ${ }^{100}$, los tratados internacionales de derechos humanos que no pueden suspenderse en estados de excepción, principios internacionales; tratados de límites que reconocen derechos intangibles ${ }^{101}$; los instrumentos de DIH que se aplican aun en situaciones de grave anormalidad ${ }^{102}$. Algunos convenios de la OIT. Alguna doctrina elaborada por los tribunales internacionales en relación con esas normas internacionales. Los pronunciamientos de los organismos de control de la OIT. Respecto del sentido lato, se incluyeron el articulado de la Constitución; los tratados internacionales de que trata el artículo 93 de la Carta, por las leyes

sional, Informe 309, Ginebra, marzo de 1998. Disponible en: http://www.ilo.org/dyn/normlex/ es/f?p=NORMLEXPUB:50002:0::NO::P50002_COMPLAINT_TEXT_ID:2903180

99 Corte Constitucional, Sentencia C-010-00, 19 de enero de 2000, magistrado ponente Alejandro Martínez-Caballero. Disponible en: http://www.corteconstitucional.gov.co/ relatoria/2000/c-010-00.htm: "es indudable que la jurisprudencia de las instancias internacionales, encargadas de interpretar esos tratados, constituye un criterio hermenéutico relevante para establecer el sentido de las normas constitucionales sobre derechos fundamentales", concretamente la producida para interpretar la Convención Americana.

100 Corte Constitucional, Sentencia C-472-92, 23 de julio de 1992, magistrado ponente José Gregorio Hernández-Galindo. Disponible en: http://corteconstitucional.gov.co/ relatoria/1992/c-472-92.htm

101 Corte Constitucional, Sentencia C-191-98, 6 de mayo de 1998, magistrado ponente Eduardo Cifuentes-Muñoz. Disponible en: http://corteconstitucional.gov.co/relatoria/1998/c-191-98.htm

$102 \mathrm{La}$ Corte Constitucional en sus sentencias C-067-03 y C-307-09 señala que las leyes orgánicas y estatutarias hacen parte del bloque de constitucionalidad lato sensu. En este caso, la ley orgánica de presupuesto se utiliza como parámetro de constitucionalidad. En el entendido de que se refiere a aquellas disposiciones que "tienen un rango normativo superior a las leyes ordinarias", aunque a veces no tengan rango constitucional, como las leyes estatutarias y orgánicas, pero que sirven como referente necesario para la creación legal y para el control constitucional". Corte Constitucional, Sentencia C-067-03, 4 de febrero de 2003, magistrado ponente Marco Gerardo Monroy-Cabra. Disponible en: http://www.corteconstitucional.gov. co/relatoria/2003/c-067-03.htm. Corte Constitucional, Sentencia C-307-09, 29 de abril de 2009, magistrado ponente Jorge Iván Palacio-Palacio. Disponible en: http://www.corteconstitucional. gov.co/relatoria/2009/c-307-09.htm 
orgánicas y, en algunas ocasiones, por las leyes estatutarias (salvo la de administración de justicia).

De lo expuesto, puede observarse una variación de las normas que componen el bloque de constitucionalidad y que difieren de los ordenamientos estudiados en este artículo pues no comprenden tratados internacionales. Con estos pronunciamientos se ha variado el sistema de fuentes del ordenamiento jurídico colombiano y se ha ampliado el parámetro de control; esta ampliación tiene efecto en el control abstracto de constitucionalidad y en el semidifuso ${ }^{103}$ en la protección de derechos por parte de los jueces. Esa dificultad entraña la necesidad de conocer el contenido del bloque, para los ejercicios de revisión de constitucionalidad ${ }^{104} \mathrm{y}$ de amparo de derechos; en este sentido, la Corte Constitucional señala que "el control constitucional de una ley deberá verificarse no solo frente al texto formal de la Carta, sino también a partir de su comparación con otras disposiciones con carácter 'supralegal' que tienen relevancia constitucional. En otras palabras, el conjunto de normas que se utilizan como parámetro para analizar la validez constitucional de las leyes integra el denominado bloque de constitucionalidad"105.

Hasta acá, el bloque presenta una dificultad frente a los casos comparados: Francia y España, por una parte, por la variación del tipo de normas que componen el bloque, y por otra, la división entre sentido estricto y lato. La Corte Constitucional colombiana no es clara en esta diferenciación y el porqué de su creación, al incluir el preámbulo dentro del primero de los sentidos y el articulado, en el segundo sentido; esta división genera una contradicción con el tipo de fuente que es la Constitución y pone en duda su obligatoriedad.

$103 \mathrm{O}$ excepción de constitucionalidad, mediante la cual cualquier autoridad administrativa o judicial puede no aplicar una norma jurídica por contravenir la Constitución.

104 Ver al respecto: Corte Constitucional, Sentencia C-225-95, 18 de mayo de 1995, magistrado ponente Alejandro Martínez-Caballero. Disponible en: http://corteconstitucional.gov.co/ relatoria/1995/c-225-95.htm. Corte Constitucional, Sentencia C-358-97, 5 de agosto de 1997, magistrado ponente Eduardo Cifuentes-Muñoz. Disponible en: http://www.corteconstitucional. gov.co/relatoria/1997/c-358-97.htm. Corte Constitucional, Sentencia C-191-98, 6 de mayo de 1998, magistrado ponente Eduardo Cifuentes-Muñoz. Disponible en: http://corte constitucional.gov.co/relatoria/1998/c-191-98.htm. Corte Constitucional, Sentencia C-25698, 27 de mayo de 1998, magistrado ponente Fabio Morón-Díaz. Disponible en: http://www. corteconstitucional.gov.co/relatoria/1998/c-256-98.htm

105 Corte Constitucional, Sentencia C-582-99, 11 de agosto de 1999, magistrado ponente Alejandro Martínez-Caballero. Disponible en: http://www.corteconstitucional.gov.co/ relatoria/1999/c-582-99.htm 
Ahora bien, la figura del bloque de constitucionalidad en Colombia ha permitido que los tratados de derechos humanos y derecho internacional humanitario adquieran "fuerza práctica en el derecho colombiano", a diferencia de los casos comparados en que el bloque unifica derechos en Francia, y en España resuelve el problema del desarrollo territorial posconstitucional. De este modo, en Colombia, puede observarse el reconocimiento del pluralismo constitucional y de la interpretación de la Constitución en Red que permite la integración en el ámbito constitucional de normas de diversa naturaleza a la constitucional. Así mismo, permite comprender una interpretación dinámica de los derechos, tal como en España en la STC 198/2012 ${ }^{106}$, como instituciones sociales y el cambio en la cultura jurídica, adecuada al momento histórico que exige una mayor preocupación por la protección y garantía de los derechos. En este sentido, se supera la visión de jerarquías entre tribunales de diversos ordenamientos, y se evidencia la concurrencia en las jurisdicciones multiniveles, espacios en que se relacionan constantemente diversas normas materialmente constitucionales de manera horizontal ${ }^{107}$.

\section{Los tratados internacionales, guía de la interpretación constitucional}

En Colombia, los derechos consagrados en las Constituciones se están interpretando de forma evolutiva, es decir, adaptándolos a las realidades en curso, como algunos tribunales constitucionales europeos lo hacen. Esta interpretación que se presenta con la interrelación constante entre los ámbitos supranacionales y los nacionales permite la ampliación y apertura de los derechos ${ }^{108}$.

106 España, Tribunal Constitucional, Pleno, Sentencia 198/2012, STC 198/2012, 6 de noviembre de 2012, 286 Boletín Oficial del Estado, BOE, 28 de noviembre de 2012. Disponible en: https:// www.boe.es/diario_boe/txt.php?id=BOE-A-2012-14602

107 Javier García-Roca, El diálogo entre el Tribunal Europeo de Derechos Humanos y los tribunales constitucionales en la construcción de un orden público europeo, 30 Teoría y Realidad Constitucional, 183-224 (2012). Disponible en: http://revistas.uned.es/index.php/TRC/article/ view/7005/6703

108 RaÚl CANOSA-Usera, Interpretación evolutiva de los derechos fundamentales, en La ciencia del derecho procesal constitucional. Estudios en homenaje a Héctor Fix-Zamudio en sus cincuenta años como investigador del derecho, T. VI, Interpretación constitucional y jurisdicción electoral, Capítulo XV, Interpretación y argumentación constitucional, 57-98 (EDUARdo Ferrer-MaCGregor \& Arturo Zaldívar-Lelo de Larrea, coords., Instituto de Investigaciones Jurídicas de la Universidad Nacional Autónoma de México, UNAM, México, 2013). Disponible en: 
De este modo, diversas Constituciones han incluido cláusulas de interpretación de los tratados internacionales como es el caso de España en el artículo 10.2 de la Constitución ${ }^{109}$. La Constitución de Portugal ${ }^{110}$ en su artículo 16.2; la de Sudáfrica ${ }^{111}$ en su artículo 39. Se incluyen a su vez los derechos incorporados en los tratados internacionales en el ámbito constitucional, como la Constitución chilena $^{112}$ en su artículo 5.2, la Constitución argentina ${ }^{113}$ en su artículo 75.22 y el caso de Perú ${ }^{114}$ en la cuarta disposición transitoria de la Constitución de $1993^{115}$.

En Colombia, a partir del año 2000, la Corte Constitucional ha señalado la importancia hermenéutica de los tratados internacionales en el control de constitucionalidad, pero también ha sostenido que el artículo 93 debe interpretarse según los deberes y derechos consagrados en los tratados internacionales de derechos humanos ratificados por Colombia, en el entendido de que los tratados internacionales tienen un carácter prevalente en el orden interno 116 . "La interpretación de los tratados internacionales de derechos humanos no se agota en el uso de los argumentos literales o gramaticales, y es necesario en esa medida acudir a criterios

http://bibliohistorico.juridicas.unam.mx/libros/libro.htm?l=2560, http://bibliohistorico. juridicas.unam.mx/libros/7/3455/9.pdf

109 España, Constitución de 1978, 311 Boletín Oficial del Estado, BOE, 29 de diciembre de 1978, artículo 10.2. Disponible en: http://www.boe.es/diario_boe/txt.php?id=BOE-A-1978-31229

110 Portugal, Constitución [Constituição da República Portuguesa], 2 de abril de 1976, artículo 16.2. Disponible en: http://www.redipd.org/legislacion/common/legislacion/portugal/Constitucion_Portugal.pdf, http://www.parlamento.pt/Legislacao/Paginas/ConstituicaoRepublica Portuguesa.aspx

111 Sudáfrica, Constitución [Constitution of the Republic of South Africa, Act 108 of 1996], 18 de diciembre de 1996, artículo 39. Disponible en: http://www.gov.za/sites/www.gov.za/files/ images/a108-96.pdf, http://www.constitutionalcourt.org.za/site/theconstitution/thetext.htm

112 Chile, Constitución, Decreto Supremo 100, 22 de septiembre de 2005, fija el texto refundido, coordinado y sistematizado de la Constitución Política de la República de Chile, 11 de septiembre de 1980, artículo 5.2. Disponible en: http://www.leychile.cl/Navegar?idNorma=242302

113 Argentina, Constitución de la nación argentina, Ley 24.430, ordénase la publicación del texto oficial de la Constitución Nacional (sancionada en 1853 con las reformas de los años 1860 , 1866, 1898, 1957 y 1994), 15 de diciembre de 1994, artículo 75.22. Disponible en: http://servicios. infoleg.gob.ar/infolegInternet/anexos/0-4999/804/norma.htm

114 Perú, Constitución, 29 de diciembre de 1993, cuarta disposición transitoria. Disponible en: http://spij.minjus.gob.pe/CLP/contenidos.dll? $\mathrm{f}=$ templates\& $\mathrm{fn}=$ default-constitucion. htm\&vid=Ciclope:CLPdemo

115 JAVIER García-Roca, Del diálogo entre los tribunales constitucionales y las cortes supranacionales de derechos: algunas cuestiones para disputar, en Jurisdicción de la libertad en Europa e Iberoamérica, 121-164 (Raúl CANosa-Usera \& Jaime Rodríguez-Arana Muñoz, coords., Editorial Reus, Madrid, 2014).

116 Corte Constitucional, Sentencia T-483-99, 8 de julio de 1999, magistrado ponente Antonio BarreraCarbonell. Disponible en: http://www.corteconstitucional.gov.co/relatoria/1999/t-483-99.htm 
sistemáticos y teleológicos"117. Como se afirma en la misma sentencia C-028-06, los tratados internacionales deben interpretarse de manera armónica entre sí para poderlos ajustar a los cambios sociales y "desafíos internacionales". En este sentido de interpretación armónica, el bloque de constitucionalidad constituye también un límite a la libertad de configuración del legislador en materia penal, así lo reconoció en la sentencia C-205-03 ${ }^{118}$.

En sentencia C-750-08 ${ }^{119}$, la Corte sostuvo que los tratados internacionales económicos, comerciales o del derecho comunitario de

117 Corte Constitucional, Sentencia C-355-06, 10 de mayo de 2006, magistrados ponentes Jaime Araújo-Rentería, Clara Inés Vargas-Hernández, consideraciones y fundamentos, 6. Disponible en: http://www.corteconstitucional.gov.co/relatoria/2006/c-355-06.htm

118 Corte Constitucional, Sentencia C-205-03, 11 de marzo de 2003, magistrada ponente Clara Inés Vargas-Hernández. Disponible en: http://www.corteconstitucional.gov.co/ relatoria/2003/c-205-03.htm. Con la "Sentencia T-483 de 1999 la Corte Constitucional sostuvo que aunque el derecho a la libre circulación puede ser restringido durante los estados de excepción, dicha restricción debe estar encaminada a 'hacer prevalecer valiosos intereses públicos y los derechos y libertades de las personas'. En vista de que esta era la interpretación que debía dársele al derecho a la libertad de movilización de conformidad con las normas de derecho internacional que lo consagran, la Corte adujo que tales instrumentos internacionales debían entenderse incorporados al bloque de constitucionalidad como herramientas hermenéuticas para juzgar la legitimidad de la normatividad interna". Corte Constitucional, Sentencia C-06703, 4 de febrero de 2003, magistrado ponente Marco Gerardo Monroy-Cabra. Disponible en: http://www.corteconstitucional.gov.co/relatoria/2003/c-067-03.htm. En el mismo sentido, la sentencia T-568-99 aclaró que las recomendaciones del Comité de Libertad Sindical de la OIT no tienen carácter vinculante para los Estados Miembros de la Organización Internacional del Trabajo. Para que tales recomendaciones tengan efectos sobre los países Miembros se exige la adopción por el Consejo de Administración. Corte Constitucional, Sentencia T-568-99, 10 de agosto de 1999, magistrado ponente Carlos Gaviria-Díaz. Disponible en: http://www. corteconstitucional.gov.co/relatoria/1999/t-568-99.htm

119 Corte Constitucional, Sentencia C-750-08, 24 de julio de 2008, magistrada ponente Clara Inés Vargas-Hernández. Disponible en: http://www.corteconstitucional.gov.co/ relatoria/2008/c-750-08.htm. La tesis sentada en esta oportunidad se había reiterado en sentencias C-1118-05, C-864-06, C-155-07, C-502-07, C-809-07 (en esta sentencia se dijo expresamente que: "el mencionado Tratado Constitutivo del Parlamento Andino, de 1979, no constituye un convenio internacional de derechos humanos, razón por la cual no forma parte del bloque de constitucionalidad"). Comunidad Andina de Naciones, Gobiernos de Bolivia, Colombia, Ecuador, Perú y Venezuela, Tratado Constitutivo del Parlamento Andino, La Paz, 25 de octubre de 1979. Disponible en: http://www.sice.oas.org/Trade/Junac/Parl1979.pdf. Así mismo en la sentencia C-339-06, la Corte Constitucional dice que la Decisión Andina 351 de 1993 en lo tocante a los derechos morales de autor - que no los patrimoniales - hacen parte del bloque de constitucionalidad, porque regulan expresa y específicamente un derecho humano. Corte Constitucional, Sentencia C-339-06, 3 de mayo de 2006, magistrado ponente Jaime CórdobaTriviño. Disponible en: http://www.corteconstitucional.gov.co/relatoria/2006/c-339-06.htm. Comunidad Andina, Comisión del Acuerdo de Cartagena, Decisión Andina 351 de 1993, Régimen Común sobre Derecho de Autor y Derechos Conexos, Lima, Perú, a los 17 de diciembre de 1993. Disponible en: http://www.sice.oas.org/trade/junac/decisiones/dec351s.asp. En ese sentido, ver también las sentencias Corte Constitucional, Sentencia C-988-04, 12 de octubre de 2004, magistrado ponente Humberto Sierra-Porto. Disponible en: http://www.corteconstitucional. gov.co/relatoria/2004/c-988-04.htm. Corte Constitucional, Sentencia C-1118-05, 1 de noviembre de 2005, magistrada ponente Clara Inés Vargas-Hernández. Disponible en: http://www.corte 
la Comunidad Andina no hacen parte del bloque de constitucionalidad, salvo que regulen de forma directa y explícita un derecho humano. Así sucede con la Decisión 351 de 1993 sobre derechos de autor y conexos que la Corte señala se trata de un derecho humano ${ }^{120}$.

También ha sostenido que la jurisprudencia y la doctrina internacionales sirven para interpretar o aclarar el contenido de una disposición de un tratado, pero no hacen parte del bloque de constitucionalidad: se trata de criterios auxiliares de interpretación ${ }^{121}$. En sentencia C-500-14, la Corte Constitucional señala que "los pronunciamientos de la Corte Interamericana de Derechos Humanos solo obligan al Estado colombiano cuando este ha sido parte en el respectivo proceso. Esta conclusión, que reconoce el carácter definitivo e inapelable asignado por el artículo 67 de la Convención Americana de Derechos Humanos a los fallos de la Corte Interamericana, encuentra apoyo normativo directo en lo prescrito en el artículo 68.1 de la referida convención conforme al

constitucional.gov.co/relatoria/2005/c-1118-05.htm. Corte Constitucional, Sentencia C-1197-05, 22 de noviembre de 2005, magistrado ponente Humberto Sierra-Porto. Disponible en: http:// www.corteconstitucional.gov.co/relatoria/2005/c-1197-05.htm. Con respecto a los convenios de la OIT, se reitera la tesis de la sentencia T-285-06. Corte Constitucional, Sentencia T-28506, 5 de abril de 2006, magistrado ponente Álvaro Tafur-Galvis. Disponible en: http://www. corteconstitucional.gov.co/relatoria/2006/t-285-06.htm

120 En este sentido, el Convenio Constitutivo del Fondo Monetario Internacional estudiado en la sentencia C-129-04 no hace parte del bloque de constitucionalidad. En este análisis, la Corte señaló que en reiterada jurisprudencia se ha aceptado el bloque normativo internacional como integrador de la Constitución y aclaró que no todo tipo de tratados, convenios o acuerdos internacionales integran esta figura, pues para que entren al bloque de constitucionalidad debe tratarse de derechos humanos que no puedan suspenderse en estados de anormalidad; este tipo de tratado tiene como finalidad el desarrollo del comercio internacional y por esa razón no debe entrar en el bloque. Corte Constitucional, Sentencia C-129-04, 19 de febrero de 2004, magistrado ponente Marco Gerardo Monroy-Cabra. Disponible en: http://www. corteconstitucional.gov.co/relatoria/2004/c-129-04.htm. Organización de Naciones Unidas, Conferencia Monetaria y Financiera, Convenio Constitutivo del Fondo Monetario Internacional, FMI, Bretton Woods, New Hampshire, 22 de julio de 1944. Disponible en: https://www. imf.org/external/spanish/pubs/ft/aa/aa.pdf. Así, tampoco hacen parte del bloque — según la sentencia C-433-10 - los tratados internacionales sobre derecho comunitario andino esta tesis que se sostiene en esta sentencia se reitera en las providencias C-988-04, C-582-99, C-191-98 y C-358-97. Sin embargo, en la sentencia C-1490-00 se estableció una excepción: "de manera excepcionalísima, la Corte ha admitido que algunas normas comunitarias pueden integrarse al bloque de constitucionalidad, siempre y cuando se trate de una norma comunitaria que de manera explícita y directa reconozca y desarrolle derechos humanos". Corte Constitucional, Sentencia C-433-10, 2 de junio de 2010, magistrado ponente Humberto Antonio Sierra Porto. Disponible en: http://www.corteconstitucional.gov.co/relatoria/2010/c-433-10.htm

121 Corte Constitucional, Sentencia C-187-06, 15 de marzo de 2006, magistrada ponente Clara Inés Vargas-Hernández. Disponible en: http://www.corteconstitucional.gov.co/ relatoria/2006/c-187-06.htm 
cual los Estados Partes en la Convención se comprometen a cumplir la decisión de la Corte en todo caso en que sean partes"122.

Respecto a la posibilidad de volver a abrir un asunto que ya fue objeto de revisión por parte de la Corte Constitucional en consideración a "interpretaciones sobrevinientes de la Corte Interamericana de Derechos respecto de una disposición internacional integrada al parámetro de control constitucional. Eso solo podría presentarse cuando (i) el parámetro de control del asunto previamente examinado haya sido una norma integrada al bloque de constitucionalidad en sentido estricto; (ii) los pronunciamientos de la Corte Interamericana de Derechos Humanos hayan variado radicalmente y de forma clara el sentido de tal norma; (iii) la nueva interpretación resulte compatible con la Constitución Política; (iv) ofrezca un mayor grado de protección a los derechos, que el otorgado por la Constitución; (v) se integre a la ratio decidendi de las decisiones de la Corte Interamericana de Derechos Humanos; y (vi) sea uniforme y reiterada. En estos casos, destaca la Corte, el demandante tendrá la obligación de demostrar con absoluta precisión cada uno de los requisitos antes referidos" ${ }^{23}$.

\section{Convenios de la OIT, consulta previa y derecho a la salud}

Uno de los cambios importantes en materia de derechos sociales y económicos es que Colombia ha subido su estándar de protección a partir de la incorporación de Convenios internacionales en el bloque de Constitucionalidad, esto en particular puede evidenciarse en la integración de los Convenios de la Organización Internacional del Trabajo, OIT; ello ha permitido proteger derechos laborales y sociales, el derecho a la asociación, el respeto por la diversidad étnica y por el derecho a la consulta previa a las comunidades, entre otros. Estos pronunciamientos de la Corte se presentan en la mayoría de los casos por demandas de inconstitucionalidad contra normativa

\footnotetext{
122 Corte Constitucional, Sentencia C-500-14, 16 de julio de 2014, magistrado ponente Mauricio González-Cuervo. Disponible en: http://www.corteconstitucional.gov.co/ relatoria/2014/c-500-14.htm

123 Corte Constitucional, Sentencia C-500-14, 16 de julio de 2014, magistrado ponente Mauricio González-Cuervo. Disponible en: http://www.corteconstitucional.gov.co/ relatoria/2014/c-500-14.htm
} 
laboral vigente que no está teniendo en cuenta adecuadamente esos estándares internacionales. Es apreciable el cambio frente a la Constitución anterior, la de 1886, que no declaró la inconstitucionalidad de normas inferiores porque vulneraban convenios de la OIT en materia laboral. Así también, la comprensión de la diversidad étnica y la necesidad de construir decisiones con las comunidades afectadas para proteger sus intereses, por ejemplo, en los emblemáticos casos de intervenciones mineras o de hidrocarburos en sus territorios en los que la comunidad mediante consulta popular señaló que no estaban de acuerdo con dicha intervención ${ }^{124}$.

La integración de los Convenios de la OIT se permite por la previsión del artículo 53 de la Constitución Política que señala que todos los convenios en esta materia hacen parte de la legislación interna una vez son ratificados. La Corte Constitucional ha señalado que no todos los convenios ratificados hacen parte del bloque de constitucionalidad, sino aquellos que traten temas de derechos humanos en el ámbito laboral ${ }^{125}$, la Corte señalará caso a caso qué convenio integrará el bloque. Así, en sentido estricto (tienen

124 El pueblo colombiano que no quiere oro. Los habitantes de Piedras, en Tolima, rechazaron con un referendo el proyecto de explotación aurífera más grande de Colombia. ¿Los escucharán?, El Comercio, 31 de julio de 2013. Disponible en: http://elcomercio.pe/mundo/actualidad/ pueblo-colombiano-que-no-quiere-oro-noticia-1611240. Indígenas pertenecientes a la etnia Emberá Katío interpusieron una acción de tutela por la violación de la consulta previa por los proyectos de desarrollo para la ejecución de obras de infraestructura y explotación de recursos naturales en sus territorios por la construcción de una carretera y los trámites de concesión para explotación de oro. Corte Constitucional, Sentencia T-693-01, 4 de julio de 2001, magistrado ponente Jaime Araújo-Rentería. Disponible en: http://www.corteconstitucional. gov.co/relatoria/2001/t-693-01.htm. Corte Constitucional, Sentencia T-129-11, 3 de marzo de 2011, magistrado ponente Jorge Iván Palacio-Palacio. Disponible en: http://www.corteconstitucional. gov.co/relatoria/2011/t-129-11.htm

125 Corte Constitucional, sentencias C-035-05 y C-1188-05. En este caso se demandó el artículo 383 del Código Sustantivo del Trabajo, CST, que establece la posibilidad a los mayores de 14 años de sindicalizarse. El actor explica que esa disposición no tiene en cuenta a los menores de 14 años que trabajan y que deberían tener también esa posibilidad. Corte Constitucional, Sentencia C-035-05, 25 de enero de 2005, magistrado ponente Rodrigo Escobar-Gil. Disponible en: http://www.corteconstitucional.gov.co/relatoria/2005/c-035-05.htm. Corte Constitucional, Sentencia C-1188-05, 22 de noviembre de 2005, magistrado ponente Alfredo Beltrán-Sierra. Disponible en: http://www.corteconstitucional.gov.co/relatoria/2005/c-1188-05.htm. Colombia, Decreto Ley 2663, 5 de agosto de 1950, Código Sustantivo del Trabajo, 27.407 Diario Oficial, 9 de septiembre de 1950, en virtud del Estado de Sitio promulgado por el Decreto Extraordinario 3518 de 1949. Disponible en: http://www.secretariasenado.gov.co/senado/basedoc/ codigo_sustantivo_trabajo.html. Colombia, Ley 789 de 2002, por la cual se dictan normas para apoyar el empleo y ampliar la protección social y se modifican algunos artículos del Código Sustantivo de Trabajo, 45.046 Diario Oficial, 27 de diciembre de 2002. Disponible en: http://www.secretariasenado.gov.co/senado/basedoc/ley_0789_2002.html 
jerarquía constitucional) los convenios $87^{126}$ y $98^{127}$ sobre la libertad sindical, al derecho de sindicación y a la negociación colectiva; los convenios $29^{128}$ y $105^{129}$, relativos a la abolición del trabajo forzoso, el convenio $169^{130}$ sobre pueblos indígenas y tribales ${ }^{131}$. En la sentencia C-170-04, la Corte indicó que también integraba el bloque el Convenio $138^{132}$, sobre la edad mínima de trabajo, y $182^{133}$, sobre las peores formas del trabajo infantil ${ }^{134}$ y el Convenio $154^{135}$ sobre negociación colectiva como fomento de la libertad sindical ${ }^{136}$.

Respecto a las recomendaciones de la OIT, la Corte sostuvo que, aunque regularmente versan sobre las mismas materias de los convenios, no son instrumentos vinculantes toda vez que se trata de directrices que pueden llegar a orientar la política y las acciones nacionales. En ese sentido, son una fuente auxiliar para interpretar

126 Organización Internacional del Trabajo, OIT, Convenio OIT 87, sobre la libertad sindical y la protección del derecho de sindicación, San Francisco, 9 de julio de 1948. Disponible en: http:// www.ilo.org/dyn/normlex/es/f?p=1000:12100:0::NO:12100:P12100_INSTRUMENT_ID:312232

127 Organización Internacional del Trabajo, OIT, Convenio OIT 98, sobre el derecho de sindicación y de negociación colectiva, Ginebra, 1 de julio de 1941. Disponible en: http://www.ilo. org/dyn/normlex/es/f?p=1000:12100:0::NO:12100:P12100_INSTRUMENT_ID:312243

128 Organización Internacional del Trabajo, OIT, Convenio OIT 29, sobre el trabajo forzoso, Ginebra, 28 de junio de 1930. Disponible en: http://www.ilo.org/dyn/normlex/es/f?p=1000:12 100:0::NO:12100:P12100_INSTRUMENT_ID:312174

129 Organización Internacional del Trabajo, OIT, Convenio OIT 105, sobre la abolición del trabajo forzoso, Ginebra, 25 de junio de 1957. Disponible en: http://www.ilo.org/dyn/normlex/es/f?p =1000:12100:0::NO:12100:P12100_INSTRUMENT_ID:312250

130 Organización Internacional del Trabajo, OIT, Convenio OIT 169, sobre pueblos indígenas y tribales, Ginebra, 27 de junio de 1989. Disponible en: http://www.ilo.org/dyn/normlex/es/f?p =1000:12100:0::NO:12100:P12100_INSTRUMENT_ID:312314

131 Corte Constitucional, Sentencia C-401-05, 14 de abril de 2005, magistrado ponente Manuel José Cepeda-Espinosa. Disponible en: http://www.corteconstitucional.gov.co/ relatoria/2005/c-401-05.htm

132 Organización Internacional del Trabajo, OIT, Convenio OIT 138, sobre la edad mínima, Ginebra, 26 de junio de 1973. Disponible en: http://www.ilo.org/dyn/normlex/es/f?p=1000:12 100:0::NO:12100:P12100_INSTRUMENT_ID:312283

133 Organización Internacional del Trabajo, OIT, Convenio OIT 182, sobre las peores formas de trabajo infantil, Ginebra, 17 de junio de 1999. Disponible en: http://www.ilo.org/dyn/normlex/ es/f?p=1000:12100:0::NO:12100:P12100_INSTRUMENT_ID:312327

$134 \mathrm{La}$ doctrina de esta sentencia es reiterada en parte por las sentencias C-170-04 y C-466-08. Corte Constitucional, Sentencia C-170-04, 2 de marzo de 2004, magistrado ponente Rodrigo EscobarGil. Disponible en: http://www.corteconstitucional.gov.co/relatoria/2004/c-170-04.htm. Corte Constitucional, Sentencia C-466-08, 14 de mayo de 2008, magistrado ponente Jaime AraújoRentería. Disponible en: http://www.corteconstitucional.gov.co/relatoria/2008/c-466-08.htm

135 Organización Internacional del Trabajo, OIT, Convenio OIT 154, sobre la negociación colectiva, Ginebra, 3 de junio de 1981. Disponible en: http://www.ilo.org/dyn/normlex/es/f?p= 1000:12100:0::NO:12100:P12100_INSTRUMENT_ID:312299

136 Corte Constitucional, Sentencia C-349-09, 20 de mayo de 2009, magistrado ponente Luis Ernesto Vargas-Silva. Disponible en: http://www.corteconstitucional.gov.co/relatoria/2009/c-349-09. htm 
el Convenio, pero no tienen jerarquía constitucional (lato sensu) ${ }^{137}$. Los convenios y las recomendaciones inciden en las condiciones y en las prácticas de trabajo de todos los países del mundo, en el caso colombiano indica la Corte con su integración al Bloque, se espera reforzar el cumplimiento de los estándares internacionales establecidos en estos instrumentos.

La Corte también indicó que el Convenio 169 de la OIT hace parte del bloque de constitucionalidad ${ }^{138}$. Ese convenio crea un derecho constitucional fundamental innominado: el derecho a la consulta previa a comunidades indígenas y afrodescendientes de decisiones que los afecten ${ }^{139}$. De este modo, se concurre en la sal-

137 Corte Constitucional, Sentencia T-979-04, 8 de octubre de 2004, magistrado ponente Jaime Córdoba-Triviño. Disponible en: http://www.corteconstitucional.gov.co/relatoria/2004/t-979-04. $\mathrm{htm}$. Esta sentencia fue reiterada en la providencia C-696-08. Sobre algunos convenios de la OIT que han sido considerados como integrantes del bloque de constitucionalidad (los convenios 87 y 88 de la OIT). Corte Constitucional, Sentencia T-568-99, 10 de agosto de 1999, magistrado ponente Carlos Gaviria-Díaz. Disponible en: http://www.corteconstitucional.gov. co/relatoria/1999/t-568-99.htm

138 Organización Internacional del Trabajo, OIT, Convenio OIT 169, sobre pueblos indígenas y tribales, Ginebra, 27 de junio de 1989. Disponible en: http://www.ilo.org/dyn/normlex/es/f?p= 1000:12100:0::NO:12100:P12100_INSTRUMENT_ID:312314. Corte Constitucional, Sentencia C-175-09, 18 de marzo de 2009, magistrado ponente Luis Ernesto Vargas-Silva. Disponible en: http://www.corteconstitucional.gov.co/relatoria/2009/c-175-09.htm. Esta sentencia reitera la tesis de las sentencias C-418-02, C-891-02, C-401-05, C-575-06, C-208-07, C-030-08, SU039-97, T-652-98, T-703-08. Corte Constitucional, Sentencia C-418-02, 28 de mayo de 2002, magistrado ponente Álvaro Tafur-Galvis. Disponible en: http://www.corteconstitucional. gov.co/relatoria/2002/c-418-02.htm. Corte Constitucional, Sentencia C-891-02, 22 de octubre de 2002, magistrado ponente Jaime Araújo-Rentería. Disponible en: http://www.corteconstitucional.gov.co/relatoria/2002/c-891-02.htm. Corte Constitucional, Sentencia C-401-05, 14 de abril de 2005, magistrado ponente Manuel José Cepeda-Espinosa. Disponible en: http:// www.corteconstitucional.gov.co/relatoria/2005/c-401-05.htm. Corte Constitucional, Sentencia C-575-06, 25 de julio de 2006, magistrado ponente Álvaro Tafur-Galvis. Disponible en: http:// www.corteconstitucional.gov.co/relatoria/2006/c-575-06.htm. Corte Constitucional, Sentencia C-208-07, 21 de marzo de 2007, magistrado ponente Rodrigo Escobar-Gil. Disponible en: http:// www.corteconstitucional.gov.co/relatoria/2007/c-208-07.htm. Corte Constitucional, Sentencia C-030-08, 23 de enero de 2008, magistrado ponente Rodrigo Escobar-Gil. Disponible en: http://www.corteconstitucional.gov.co/relatoria/2008/c-030-08.htm. Corte Constitucional, Sentencia SU-039-97, 3 de febrero de 1997, magistrado ponente Antonio Barrera-Carbonell. Disponible en: http://www.corteconstitucional.gov.co/relatoria/1997/su039-97.htm. Corte Constitucional, Sentencia T-652-98, 10 de noviembre de 1998, magistrado ponente Carlos Gaviria-Díaz. Disponible en: http://www.corteconstitucional.gov.co/relatoria/1998/t-652-98. $\mathrm{htm}$. Corte Constitucional, Sentencia T-703-08, 10 de julio de 2008, magistrado ponente Manuel José Cepeda-Espinosa. Disponible en: http://www.corteconstitucional.gov.co/ relatoria/2008/t-703-08.htm

139 En esta oportunidad, la Corte Constitucional analiza la Ley 1152 de 2007 (estatuto de desarrollo rural) que fue aprobada sin la participación de comunidades indígenas, a pesar de que esa disposición legal afectaba a esas comunidades. En esta sentencia, la Corte declaró inexequible la Ley 1152 de 2007. Corte Constitucional, Sentencia C-375-09, 27 de mayo de 2009, magistrado ponente Nilson Pinilla-Pinilla. Disponible en: http://www.corteconstitucional.gov. co/relatoria/2009/C-375-09.htm. Colombia, Ley 1152 de 2007, por la cual se dicta el Estatuto 
vaguarda de la identidad de las comunidades indígenas y tribales, la protección de su territorio y, de manera general, su subsistencia como grupo diferenciado.

Ahora bien, otro de los cambios importantes en 2008 en lo atinente a derechos sociales es que mediante la sentencia T-760-08 ${ }^{140}$, la Corte señaló que el derecho a la salud era fundamental (este derecho era un derecho social de corte programático en la Constitución). Según la Corte Constitucional, el derecho a la salud en un Estado social de derecho "debe comprender el derecho al nivel más alto de salud posible, el cual se alcanza de manera progresiva" y "todas las autoridades competentes deben colaborar y dirigir sus actividades para tal fin". Para adoptar este concepto de salud como derecho fundamental, la Corte adopta como parte del bloque de constitucionalidad la Observación general 14 del 11 de agosto de 2000 del Comité de Derechos Económicos, Sociales y Culturales $(\mathrm{CESCR})^{141}$. Esta observación se integra al bloque de constitucionalidad por ser el "más amplio desarrollo acerca del derecho a la

de Desarrollo Rural, se reforma el Instituto Colombiano de Desarrollo Rural, Incoder, y se dictan otras disposiciones, 46.700 Diario Oficial, 25 de julio de 2007. Disponible en: http:// www.secretariasenado.gov.co/senado/basedoc/ley_1152_2007.html

140 Corte Constitucional, Sentencia T-760-08, 31 de julio de 2008, magistrado ponente Manuel José Cepeda-Espinosa. Disponible en: http://www.corteconstitucional.gov.co/ relatoria/2015/t-760-08.htm

141 "El Comité de Derechos Económicos, Sociales y Culturales (CESCR) es el órgano de expertos independientes que supervisa la aplicación del Pacto Internacional de Derechos Económicos, Sociales y Culturales por sus Estados Partes. El Comité se estableció en virtud de la resolución 1985/17, de 28 de mayo de 1985, del Consejo Económico y Social de las Naciones Unidas (ECOSOC) para desempeñar las funciones de supervisión asignadas a este Consejo en la parte IV del Pacto". Página institucional del Comité (CESCR) en la red internet: http:// www.derechoshumanos.net/ONU/ComiteDerechosEconomicosSocialesCulturales-CESCR. htm. El Comité de Derechos Económicos, Sociales y Culturales es un órgano creado a raíz de la defectuosa actuación de dos órganos a los que se había encomendado anteriormente la vigilancia del Pacto. El Comité lo integran 18 expertos de reconocida competencia en materia de derechos humanos, elegidos por el Consejo Económico y Social para mandatos de cuatro años con posibilidad de ser reelegidos. En el proceso de selección se observan los principios de distribución geográfica equitativa y de representación de distintos sistemas sociales y jurídicos. La función primordial del Comité es vigilar la aplicación del Pacto por los Estados Partes. Organización de Naciones Unidas, ONU, Comité de Derechos Económicos, Sociales y Culturales, CESCR, Folleto informativo No. 16 (Rev. 1) (Oficina del Alto Comisionado de las Naciones Unidas para los Derechos Humanos, OACNUDH, Ginebra, 1996). Disponible en: http://www.ohchr.org/Documents/Publications/FactSheet16Rev.1sp. pdf. Organización de Naciones Unidas, ONU, Comité de Derechos Económicos, Sociales y Culturales, CESCR, Observación general 14, 11 de agosto de 2000, El derecho al disfrute del más alto nivel posible de salud (artículo 12). Disponible en: http://conf-dts1.unog.ch/1\%20SPA/ Tradutek/Derechos_hum_Base/CESCR/00_1_obs_grales_Cte $\% 20$ Dchos $\% 20$ Ec $\% 20$ Soc $\% 20$ Cult.html\#GEN14 
salud, su alcance y significado, acerca 'el derecho al disfrute del más alto nivel posible de salud".

Así también integra la Observación general 19 del Comité de Derechos Económicos, Sociales y Culturales (referente a seguridad social $)^{142}$ hace parte del bloque en sentido estricto ${ }^{143}$. El Comité de Derechos Económicos, Sociales y Culturales destacó la enorme importancia que ostenta esta garantía en el contexto de plena satisfacción de los derechos humanos ${ }^{144}$, en la medida en que el derecho a la seguridad social adquiere el estatuto de condición ineludible de tal posibilidad de goce dentro de los esfuerzos que han de llevar a cabo los Estados para superar las condiciones materiales de pobreza y miseria que se oponen al disfrute de las libertades individuales. De manera precisa, en cuanto al contenido del derecho, el Comité señaló lo siguiente: "El derecho a la seguridad social incluye el derecho a obtener y mantener prestaciones sociales, ya sea en efectivo o en especie, sin discriminación, con el fin de obtener protección, en particular contra: a) la falta de ingresos procedentes del trabajo debido a enfermedad, invalidez, maternidad, accidente laboral, vejez o muerte de un familiar, b) gastos excesivos de atención de

142 Corte Constitucional, Sentencia T-539-09, 6 de agosto de 2009, magistrado ponente Humberto Antonio Sierra-Porto. Disponible en: http://www.corteconstitucional.gov.co/ relatoria/2009/t-539-09.htm. Organización de Naciones Unidas, ONU, Comité de Derechos Económicos, Sociales y Culturales, CESCR, Observación general 19, 4 de febrero de 2008, El derecho a la seguridad social (artículo 9). Disponible en: http://conf-dts1.unog.ch/1\%20SPA/ Tradutek/Derechos_hum_Base/CESCR/00_1_obs_grales_Cte $\% 20$ Dchos $\% 20$ Ec $\% 20$ Soc $\% 20$ Cult.html\#GEN19

$143 \mathrm{El}$ accionante es un adulto mayor cuya pensión sustitutiva fue negada por la Caja Nacional de Previsión Social, Cajanal, en la medida en que al parecer los hechos ocurrieron antes de la entrada en vigencia de la Ley 100 de 1993. El tutelante reclama su derecho a la seguridad social. La Corte Constitucional admite tácitamente que la Observación general 19 hace parte del bloque de constitucionalidad. Colombia, Ley 100 de 1993, por la cual se crea el sistema de seguridad social integral y se dictan otras disposiciones, 41.148 Diario Oficial, 23 de diciembre de 1993. Disponible en: http://www.secretariasenado.gov.co/senado/basedoc/ley_0100_1993. html. En sentencias de tutela, la Corte reconoce el derecho a la seguridad social en estricto sentido. Corte Constitucional, Sentencia T-069-14, 3 de febrero de 2014, magistrada ponente María Victoria Calle-Correa. Disponible en: http://www.corteconstitucional.gov.co/ relatoria/2014/T-069-14.htm

144 De manera textual, el Comité señaló: "El derecho a la seguridad social es de importancia fundamental para garantizar a todas las personas su dignidad humana cuando hacen frente a circunstancias que les privan de su capacidad para ejercer plenamente los derechos reconocidos en el Pacto". Organización de Naciones Unidas, ONU, Comité de Derechos Económicos, Sociales y Culturales, CESCR, Observación general 19, 4 de febrero de 2008, El derecho a la seguridad social (artículo 9). Disponible en: http://conf-dtsl.unog.ch/1\%20SPA/Tradutek/ Derechos_hum_Base/CESCR/00_1_obs_grales_Cte $\% 20$ Dchos $\% 20$ Ec $\% 20$ Soc $\% 20$ Cult. html\#GEN19 
salud; c) apoyo familiar insuficiente, en particular para los hijos y los familiares a cargo" 145 .

\section{Derecho a la no discriminación de las mujeres, derechos reproductivos y protección frente a la violencia}

Otro de los contenidos en derechos que ha generado el bloque es el relativo a la igualdad entre mujeres y hombres y a la protección de la libertad reproductiva de la mujer. Estos pronunciamientos se presentan por acciones de inconstitucionalidad contra acciones afirmativas reconocidas legalmente o por normativa que desconoce el derecho a la igualdad, lo cual vulnera la Carta y los tratados internacionales correspondientes.

Como parámetro de control, la Corte Constitucional en sentencia C-667-06 $6^{146}$ utiliza de forma indirecta la Observación general 18 del Comité de Derechos Humanos de las Naciones Unidas, en relación con el derecho a la no discriminación consagrado en el Pacto de Derechos Civiles y Políticos acerca de que deben adoptarse disposiciones o acciones afirmativas para poder corregir los problemas de discriminación en los ámbitos internos ${ }^{147}$. Las acciones afirmativas son mecanismos para modular el derecho a la igualdad; en ese sentido, la Convención Internacional sobre la Eliminación de Todas las Formas de Discriminación Racial ${ }^{148}$ y la Convención Internacional sobre la Eliminación de Todas las Formas de Discriminación contra

145 Corte Constitucional, Sentencia T-201-14, 1 de abril de 2014, magistrado ponente Alberto Rojas-Ríos. Disponible en: http://www.corteconstitucional.gov.co/relatoria/2014/t-201-14.htm. Organización de Naciones Unidas, ONU, Comité de Derechos Económicos, Sociales y Culturales, CESCR, Observación general 19, 4 de febrero de 2008, El derecho a la seguridad social (artículo 9). Disponible en: http://conf-dts1.unog.ch/1\%20SPA/Tradutek/Derechos_hum_Base/ CESCR/00_1_obs_grales_Cte\%20Dchos\%20Ec\%20Soc\%20Cult.html\#GEN19

146 Corte Constitucional, Sentencia C-667-06, 16 de agosto de 2006, magistrado ponente Jaime Araújo-Rentería. Disponible en: http://www.corteconstitucional.gov.co/ relatoria/2006/c-575-06.htm

147 Organización de Naciones Unidas, ONU, Comité de los Derechos Humanos, Observación general 18, 10 de noviembre de 1989, No discriminación. Disponible en: http://www.acnur. org/t3/fileadmin/scripts/doc.php?file=t3/fileadmin/Documentos/BDL/2001/1404, http://www1. umn.edu/humanrts/hrcommittee/Sgencom18.html

148 Organización de Naciones Unidas, ONU, Convención Internacional sobre la Eliminación de Todas las Formas de Discriminación Racial, Asamblea General, Resolución 2106 A (XX), 21 de diciembre de 1965. Disponible en: http://www.ohchr.org/SP/ProfessionalInterest/Pages/ CERD.aspx 
la Mujer ${ }^{149}$ reconocen la posibilidad de la discriminación positiva o acciones afirmativas en ciertas condiciones ${ }^{150}$.

El contenido de los derechos sexuales y reproductivos se incorpora al ordenamiento interno gracias a la Convención Internacional sobre la Eliminación de Todas las Formas de Discriminación contra la Mujer (Convention on the Elimination of all forms of Discrimination Against Women, CEDAW) que, a su vez, hace parte del bloque de constitucionalidad ${ }^{151}$. De esta manera, crea un nuevo derecho a la autodeterminación reproductiva. "El ámbito de la sexualidad debe estar libre de todo tipo de discriminación ${ }^{152}$, violencia física o psíquica, abuso, agresión o coerción, de esta forma se proscriben, por ejemplo, la violencia sexual, la esclavitud sexual, la prostitución forzada ${ }^{153}$ ".

Posteriormente, reitera la protección, sensibilización, prevención y sanción de formas de violencia y discriminación contra las mujeres implica el derecho fundamental a la salud y la violencia implica no solo "la ausencia de afecciones y enfermedades en una persona, sino un estado completo de bienestar físico, mental y social, acorde con

149 Organización de Naciones Unidas, ONU, Convención Internacional sobre la Eliminación de Todas las Formas de Discriminación contra la Mujer, Asamblea General, Resolución 34/180, 18 de diciembre de 1979. http://www.ohchr.org/SP/ProfessionalInterest/Pages/CEDAW.aspx

150 Artículo 4.1 de la Convención. La demanda se refiere a la demanda de inconstitucionalidad contra el numeral 5 del artículo 3 (parcial) de la Ley 136 de 1994: "Solucionar las necesidades insatisfechas de salud, educación, saneamiento ambiental, agua potable, servicios públicos domiciliarios, vivienda recreación y deporte, con especial énfasis en la niñez, la mujer, la tercera edad y los sectores discapacitados, directamente y, en concurrencia, complementariedad y coordinación con las demás entidades territoriales y la Nación, en los términos que defina la ley". La expresión mujer fue demandada por no considerar al hombre. Corte Constitucional, Sentencia C-667-06, 16 de agosto de 2006, magistrado ponente Jaime Araújo-Rentería. Disponible en: http://www.corteconstitucional.gov.co/relatoria/2006/c-575-06.htm. Colombia, Ley 136 de 1994, por la cual se dictan normas tendientes a modernizar la organización y el funcionamiento de los municipios, 41.377 Diario Oficial, 2 de junio de 1994. Disponible en: http://www.secretariasenado.gov.co/senado/basedoc/ley_0136_1994.html

151 Corte Constitucional, Sentencia T-732-09, 15 de octubre de 2009, magistrado ponente Humberto Antonio Sierra-Porto. Disponible en: http://www.corteconstitucional.gov.co/ relatoria/2009/t-732-09.htm

$152 \mathrm{Al}$ respecto se puede citar toda la jurisprudencia constitucional en torno a la prohibición de discriminación de las personas homosexuales. Corte Constitucional, Sentencia C-029-09, 28 de enero de 2009, magistrado ponente Rodrigo Escobar-Gil. Disponible en: http://www. corteconstitucional.gov.co/relatoria/2009/c-029-09.htm

153 Organización de Estados Americanos, OEA, Convención Interamericana para Prevenir, Sancionar y Erradicar la Violencia contra la Mujer, Convención de Belém do Pará, Belém do Pará, 9 de junio de 1994, artículos 1, 2 y 3. Ratificada por Colombia en 1996. Disponible en: http://www.oas.org/juridico/spanish/tratados/a-61.html. En el mismo sentido, Organización de Naciones Unidas, ONU, Convención sobre los Derechos del Niño, Asamblea General, Resolución 44/25, 20 de noviembre de 1989, artículos 14 y 19. Disponible en: http://www.ohchr. org/SP/ProfessionalInterest/Pages/crc.aspx 
las posibilidades y las condiciones dentro de las cuales la persona se relaciona con el Estado, su familia y los demás integrantes de la comunidad"'154.

En sentencia T-878-14 155 indica que los instrumentos internacionales para eliminar la violencia y la discriminación imponen obligaciones de previsión y sanción a los Estados; no obstante, la Corte ha señalado que "solo la CEDAW ha sido considerada parte del bloque de Constitucionalidad en sentido estricto, las demás convenciones, instrumentos y decisiones nombradas tienen un valor interpretativo determinante al momento de aplicar los contenidos de los compromisos adquiridos por Colombia, a la luz del numeral 2 del artículo 93 Superior"'156.

\section{Protección del derecho a la vida y protección frente al desplazamiento forzado}

En la sentencia C-488-09157 se señaló que las normas consuetudinarias del DIH hacen parte del bloque; por regla general, las normas de derecho penal internacional no hacen parte de bloque, salvo que guarden relación directa con la protección de derechos humanos o DIH. De acuerdo con esto, unas partes (el artículo 6)

154 Para llegar a esta conclusión estudia armónicamente los siguientes tratados internacionales que hacen parte del bloque: la Declaración Universal de Derechos Humanos, adoptada por la Asamblea General de las Naciones Unidas en 1948 (artículos 1 a 3). La Recomendación 19, adoptada en 1992 por el Comité para la Eliminación de la Discriminación contra de la Mujer. Convención para la Eliminación de Todas las Formas de Discriminación contra la Mujer (CEDAW), aprobada mediante Ley 51 de 1981. Declaración y Plataforma de Acción de Beijing, de 1995. Convención Interamericana para Prevenir, Sancionar y Erradicar la Violencia contra la Mujer, Convención de Belém do Pará, aprobada mediante Ley 248 de 1995. Resolución 1325 del Consejo de Seguridad de Naciones Unidas, adoptada por el Consejo de Seguridad el 31 de octubre de 2000. Protocolo para Prevenir, Reprimir y Sancionar la Trata de Personas, especialmente Mujeres y Niños, que complementa la Convención de las Naciones Unidas contra la Delincuencia Organizada Transnacional, aprobado mediante Ley 800 de 2003. Protocolo Facultativo de la Convención sobre la Eliminación de todas las formas de Discriminación contra la Mujer, aprobado mediante Ley 984 de 2005.

155 Corte Constitucional, Sentencia T-878-14, 18 de noviembre de 2014, magistrado ponente Jorge Iván Palacio-Palacio. Disponible en: http://www.corteconstitucional.gov.co/ relatoria/2014/t-878-14.htm

156 Al respecto, Corte Constitucional, Sentencia C-355-06, 10 de mayo de 2006, magistrados ponentes Jaime Araújo-Rentería, Clara Inés Vargas-Hernández. Disponible en: http://www. corteconstitucional.gov.co/relatoria/2006/c-355-06.htm

157 Corte Constitucional, Sentencia C-488-09, 22 de julio de 2009, magistrado ponente Jorge Iván Palacio-Palacio. Disponible en: http://www.corteconstitucional.gov.co/relatoria/2009/c-488-09. htm. Esta sentencia reitera la C-291-07. Corte Constitucional, Sentencia C-291-07, 25 de abril de 2007, magistrado ponente Manuel José Cepeda-Espinosa. Disponible en: http://www. corteconstitucional.gov.co/relatoria/2007/c-291-07.htm 
del Estatuto de Roma ${ }^{158}$ y la Convención sobre Genocidio ${ }^{159}$ hacen parte del bloque en la medida en que se trata de normas de ius cogens que se incorporan al bloque. La Corte concluye que tanto (i) la Convención para la Prevención y la Sanción del Delito de Genocidio, como (ii) el artículo 6 del Estatuto de Roma de la Corte Penal Internacional, que coincide con aquella, se incorporan al bloque de constitucionalidad en aras del control que debe adelantar esta Corporación. En consecuencia, la libertad de configuración del legislador en la regulación del genocidio está limitada por el deber de armonizar la normatividad interna con los parámetros internacionales allí fijados.

La sentencia T-042-09160 integró al bloque los principios rectores de los desplazamientos internos, consagrados en el Informe del representante especial del secretario general de Naciones Unidas para el tema de los desplazamientos internos de personas ${ }^{161}$. La

158 Organización de Naciones Unidas, ONU, Estatuto de Roma de la Corte Penal Internacional, Roma, 17 de julio de 1998. Disponible en: http://www.un.org/spanish/law/icc/statute/spanish/ rome_statute(s).pdf

159 Organización de Naciones Unidas, ONU, Convención para la Prevención y la Sanción del Delito de Genocidio, Asamblea General, Resolución 260 A (III), 9 de diciembre de 1948. Disponible en: https://www.icrc.org/spa/resources/documents/misc/treaty-1948-conv-genocide5tdm6h.htm

160 Corte Constitucional, Sentencia T-042-09, 29 de enero de 2009, magistrado ponente Jaime Córdoba-Triviño. Disponible en: http://www.corteconstitucional.gov.co/relatoria/2009/t-042-09. $\mathrm{htm}$. Sobre el mismo tema, sentencias T-319-09, T-006-09, T-1134-08, T-056-08, C-278 de 2007. En esta providencia se dijo: "estos Principios Rectores $\unrhd$ pueden, entonces (i) ser normas relevantes para resolver casos específicos, y (ii) tener verdadero rango constitucional, si son preceptos que reiteran normas incluidas en tratados de derechos humanos o de derecho humanitario. El uso (i) denota que ciertos principios o algunos de sus párrafos hacen parte de lo que la Corte ha denominado bloque de constitucionalidad en sentido lato, mientras que el uso (ii) denota que algunos de entre ellos forman parte del bloque de constitucionalidad en estricto sentido, ya que tienen jerarquía constitucional e, incluso, sirven de parámetro para evaluar la constitucionalidad de las leyes". Corte Constitucional, Sentencia C-278-07, 18 de abril de 2007, magistrado ponente Nilson Pinilla-Pinilla. Disponible en: http://www. corteconstitucional.gov.co/relatoria/2007/c-278-07.htm, que cita la T-602-03. Corte Constitucional, Sentencia T-602-03, 23 de julio de 2003, magistrado ponente Jaime Araújo-Rentería. Disponible en: http://www.corteconstitucional.gov.co/relatoria/2003/t-602-03.htm. Corte Constitucional, Sentencia T-056-08, 25 de enero de 2008, magistrado ponente Jaime CórdobaTriviño. Disponible en: http://www.corteconstitucional.gov.co/relatoria/2008/t-056-08.htm. Corte Constitucional, Sentencia T-1134-08, 14 de noviembre de 2008, magistrado ponente Manuel José Cepeda-Espinosa. Disponible en: http://www.corteconstitucional.gov.co/ relatoria/2008/t-1134-08.htm. Corte Constitucional, Sentencia T-006-09, 16 de enero de 2009, magistrado ponente Jaime Córdoba-Triviño. Disponible en: http://www.corteconstitucional. gov.co/relatoria/2009/t-006-09.htm. Corte Constitucional, Sentencia T-319-09, 7 de mayo de 2009, magistrado ponente Jorge Iván Palacio-Palacio. Disponible en: http://www.corteconstitucional.gov.co/relatoria/2009/t-319-09.htm

$161 \mathrm{La}$ accionante es una señora desplazada a quien le fue negada la solicitud de inscripción en el Registro Único de Población Desplazada, RUPD. Acción Social expresó que, en este caso, el 
Corte Constitucional ha decantado y sistematizado los principios que deben guiar la interpretación de las disposiciones relativas a la inscripción en el Sistema Único de Registro de Desplazados, RUPD, $\mathrm{y}$ ha señalado algunos elementos que deben ser tenidos en cuenta por las autoridades encargadas de recibir y tramitar las declaraciones de quienes se consideran víctimas de desplazamiento forzado, para que sus decisiones respeten la condición de sujetos de especial protección constitucional que cobija a este grupo poblacional.

\section{Derechos de los niños}

En la sentencia T-078-10 162 , la Corte señala que hacen parte del bloque de constitucionalidad la Declaración de Ginebra de 1924 sobre los Derechos del Niño ${ }^{163}$, la Convención de los Derechos del Niño adoptada por la Asamblea General de las Naciones Unidas, el 20 de noviembre de $1989^{164}$, y reconocida en la Declaración Universal de Derechos Humanos ${ }^{165}$, el Pacto Internacional de Derechos Civiles y Políticos ${ }^{166}$, el Pacto Internacional de Derechos Económicos,

desplazamiento no obedece a motivos ideológicos o políticos, sino meramente sentimentales. Corte Constitucional, Sentencia T-042-09, 29 de enero de 2009, magistrado ponente Jaime Córdoba-Triviño. Disponible en: http://www.corteconstitucional.gov.co/relatoria/2009/t-042-09. htm. Organización de Naciones Unidas, ONU, Informe del representante especial del secretario general de Naciones Unidas para el tema de los Desplazamientos Internos de Personas, Sr. Francis Deng, Doc. E/CN.4/1998/53/Add.2, 11 de febrero de 1998. Disponible en: http:// www.hchr.org.co/documentoseinformes/documentos/html/informes/onu/resdi/E-CN-4-199853-ADD-2.html

162 Corte Constitucional, Sentencia T-078-10, 11 de febrero de 2010, magistrado ponente Luis Ernesto Vargas-Silva. Disponible en: http://www.corteconstitucional.gov.co/ relatoria/2010/t-078-10.htm. Esta sentencia reitera las providencias C-997-04, C-118-06 y C-1003-07. Corte Constitucional, Sentencia C-997-04, 12 de octubre de 2004, magistrado ponente Jaime Córdoba-Triviño. Disponible en: http://www.corteconstitucional.gov.co/ relatoria/2004/c-997-04.htm. Corte Constitucional, Sentencia C-118-06, 22 de febrero de 2006, magistrado ponente Jaime Araújo-Rentería. Disponible en: http://www.corteconstitucional. gov.co/relatoria/2006/c-118-06.htm. Corte Constitucional, Sentencia C-1003-07, 22 de noviembre de 2007, magistrada ponente Clara Inés Vargas-Hernández. Disponible en: http://www. corteconstitucional.gov.co/relatoria/2007/c-1003-07.htm

163 Sociedad de las Naciones, SDN, Declaración de Ginebra sobre los Derechos del Niño, Ginebra, 24 de septiembre de 1924. Disponible en: http://www.un-documents.net/gdrc1924.htm, http:// www.humanium.org/fr/normes/declaration-de-geneve-1924/texte-integral-declaration-degeneve/

164 Organización de Naciones Unidas, ONU, Convención sobre los Derechos del Niño, Asamblea General, Resolución 44/25, 20 de noviembre de 1989. Disponible en: http://www.ohchr.org/ $\mathrm{SP} /$ ProfessionalInterest/Pages/crc.aspx

165 Organización de Naciones Unidas, ONU, Declaración Universal de Derechos Humanos, París, 10 de diciembre de 1948. Disponible en: http://www.un.org/es/documents/udhr/

166 Organización de Naciones Unidas, ONU, Pacto Internacional de Derechos Civiles y Políticos, Asamblea General, Resolución 2200 A (XXI), 16 de diciembre de 1966. Disponible en: http:// 
Sociales y Culturales (en particular, en el artículo 10) ${ }^{167}$, la Convención Interamericana sobre Tráfico Internacional de Menores ${ }^{168}$ y el Convenio relativo a la Protección del Niño y a la Cooperación en Materia de Adopción Internacional ${ }^{169}$ hacen parte del bloque de constitucionalidad ${ }^{170}$.

De este modo, en la sentencia C-203-05 ${ }^{171}$, la Corte señaló que las Reglas de Beijing o Reglas mínimas de las Naciones Unidas para la Administración de la Justicia de Menores ${ }^{172}$ y la resolución sobre estándares mínimos a aplicar en todos los casos de privación de la libertad de menores de edad, hacen parte tácitamente del bloque de constitucionalidad, porque deben ser respetadas en todos los casos de procesamiento de menores de edad por violación de la ley penal, así como la compilación de estándares mínimos a aplicar en todos los casos de privación de la libertad de menores de edad.

Respecto a la violencia sexual contra niños y niñas, la Corte indicó que todos los actores que intervienen en la atención judicial y psicológica de niños y niñas víctimas de delitos sexuales deben seguir las recomendaciones y obligaciones señaladas por la Corte,

www.ohchr.org/SP/ProfessionalInterest/Pages/CCPR.aspx

167 Organización de Naciones Unidas, ONU, Pacto Internacional de Derechos Económicos, Sociales y Culturales, 16 de diciembre de 1966. Disponible en: http://www.ohchr.org/SP/ ProfessionalInterest/Pages/CESCR.aspx

168 Organización de Estados Americanos, OEA, Convención Interamericana sobre Tráfico Internacional de Menores, Ciudad de México, 18 de marzo de 1994. Disponible en: http:// www.oas.org/dil/esp/tratados_B-57_Convencion_Interamericana_sobre_Trafico_Internacional_de_Menores.htm

169 Hague Conference on Private International Law, $\mathrm{HCCH}$, Convenio relativo a la Protección del Niño y a la Cooperación en Materia de Adopción Internacional, La Haya, 29 de mayo de 1993. Disponible en: https://www.hcch.net/es/instruments/conventions/specialised-sections/ intercountry-adoption, http://www.oas.org/dil/esp/Convenio_Haya_Proteccion_del_Nino_ Cooperacion_en_Materia_Adopcion_Internacional_Espana.pdf

170 Se interpuso una acción de tutela contra una decisión de la Fiscalía General de la Nación, que precluyó la investigación en contra del padre de unos niños de los que — presuntamenteabusó.

171 La Corte Constitucional, en la sentencia C-203-05, analizó en esta oportunidad, la constitucionalidad del parágrafo 2, del artículo 19 de la Ley 782 de 2002, que establece unas reglas para el indulto de menores de edad que hubiesen pertenecido a grupos al margen de la ley. Según los accionantes, los casos de los menores como víctimas del conflicto (reclutamiento) deben ser conocidos por el ICBF y no por la justicia de menores, en la medida en que son víctimas y no victimarios. Corte Constitucional, Sentencia C-203-05, 8 de marzo de 2005, magistrado ponente Manuel José Cepeda-Espinosa. Disponible en: http://www.corteconstitucional.gov. co/relatoria/2005/c-203-05.htm

172 Organización de Naciones Unidas, ONU, Reglas Mínimas de las Naciones Unidas para la Administración de la Justicia de Menores, Reglas de Beijing, Asamblea General, Resolución 40/33, 28 de noviembre de 1985. Disponible en: http://www.ohchr.org/SP/ProfessionalInterest/ Pages/BeijingRules.aspx 
en desarrollo de estos instrumentos internacionales; no cumplirlas implicaría la vulneración de la Constitución. Los pronunciamientos de la Corte Constitucional en desarrollo de esa normativa internacional y nacional han determinado unos principios de la actuación de todas las autoridades cuando se está frente a un menor y unos parámetros a tener en cuenta en estas actuaciones. La Corte ha desarrollado una línea jurisprudencial en el marco de las obligaciones internacionales respecto de la protección a los niños y niñas, así, en la sentencia hito C-1068-02 $2^{173}$, la Corte Constitucional señaló que la comunidad internacional se ha propuesto una especial protección a los niños para permitirles un crecimiento, desarrollo e integración en la sociedad. Esta necesidad de especial protección del Estado se recoge en los instrumentos internacionales y se predica de toda persona menor de 18 años ${ }^{174}$.

Respecto al tema de la violencia sexual contra niños, en la sentencia T-078-10 175 , se señalan otros instrumentos que integran al bloque de constitucionalidad en materia de protección a los niños contra la violencia sexual:

- La Convención Interamericana sobre Tráfico Internacional de Menores; el Convenio Relativo a la Protección del Niño y a la Cooperación en Materia de Adopción Internacional.

- El artículo 44 de la Constitución Política. Los artículos 18 y 20 de la nueva Ley de Infancia 1098 de $2006^{176}$.

173 Corte Constitucional, Sentencia C-1068-02, 3 de diciembre de 2002, magistrado ponente Jaime Araújo-Rentería. Disponible en: http://www.corteconstitucional.gov.co/ relatoria/2002/c-1068-02.htm

174 "La Corte, con un gran sentido garantista y proteccionista ha considerado que es niño, todo ser humano menor de 18 años, siguiendo los parámetros de la Convención sobre los Derechos del Niño, aprobada mediante Ley 12 de 1991". Corte Constitucional, Sentencia C-1068-02, 3 de diciembre de 2002, magistrado ponente Jaime Araújo-Rentería. Disponible en: http:// www.corteconstitucional.gov.co/relatoria/2002/c-1068-02.htm. Colombia, Ley 12 de 1991, por medio de la cual se aprueba la Convención sobre los Derechos del Niño, adoptada por la Asamblea General de las Naciones Unidas el 20 de noviembre de 1989, 39.640 Diario Oficial, 22 de enero de 1991. Disponible en: http://www.alcaldiabogota.gov.co/sisjur/normas/Norma1. jsp?i $=10579$

175 Se interpuso una acción de tutela contra una decisión de la Fiscalía General de la Nación, que precluyó la investigación en contra del padre de una niña menor de 4 años que presuntamente abusaba de ella. Corte Constitucional, Sentencia T-078-10, 11 de febrero de 2010, magistrado ponente Luis Ernesto Vargas-Silva. Disponible en: http://www.corteconstitucional.gov.co/ relatoria/2010/t-078-10.htm. Esta sentencia reitera las providencias C-1003-07, C-118-06 y C-997-04.

176 Colombia, Ley 1098 de 2006, por la cual se expide el Código de la Infancia y la Adolescencia, 46.446 Diario Oficial, 8 de noviembre de 2006. Disponible en: http://www.secretariasenado. gov.co/senado/basedoc/ley_1098_2006.html 
1. La Corte sostiene que estos instrumentos establecen "una serie de garantías y beneficios que los protegen en el proceso de formación y desarrollo de la infancia hacia la adultez", ello ha generado un principio orientativo "para la resolución de los conflictos que involucren a un menor, el concepto del interés superior del menor, que se ha incorporado como eje central del análisis constitucional ${ }^{177}$ ". Y que implica un trato preferente hacia el menor como "sujeto de especial protección y de la cual se deriva la titularidad de un conjunto de derechos que deben ser contrastados con las circunstancias específicas tanto del menor como de la realidad en la que se halla. "Es así que el interés superior del menor posee un contenido de naturaleza real y relacional ${ }^{178}$, criterio con el cual se exige una verificación y especial atención a los elementos concretos y particulares que distinguen a los menores, sus familias y en donde se encuentran presentes aspectos emotivos, culturales, creencias y sentimientos de gran calado en la sociedad" 179 .

177 "Constitución Política, artículo 44; Convención sobre los Derechos del Niño, artículo 3-1; Código del Menor, arts. 20 y 22. Código del Menor. Es así que el artículo 20 establece: "Las personas y las entidades tanto públicas como privadas que desarrollen programas o tengan responsabilidades en asuntos de menores, tomarán en cuenta sobre toda otra consideración, el interés superior del menor". || Código del Menor, artículo 22: "La interpretación de las normas contenidas en el presente código deberá hacerse teniendo en cuenta que su finalidad es la protección del menor". Entre otras, las sentencias T-408-95, T-041-96, T-189-03, T-510-03, T-864-05 y T-551-06 han acogido este parámetro como criterio determinante para el análisis y resolución del caso en el que se involucran los derechos de los niños, todas ellas citadas en la sentencia T-078-10. Corte Constitucional, Sentencia T-408-95, 12 de septiembre de 1995, magistrado ponente Eduardo Cifuentes-Muñoz. Disponible en: http://www.corteconstitucional.gov.co/ relatoria/1995/t-408-95.htm. Corte Constitucional, Sentencia T-041-96, 7 de febrero de 1996, magistrado ponente Carlos Gaviria-Díaz. Disponible en: http://www.corteconstitucional.gov. co/relatoria/1996/t-041-96.htm. Corte Constitucional, Sentencia T-189-03, 5 de marzo de 2003, magistrado ponente Alfredo Beltrán-Sierra. Disponible en: http://www.corteconstitucional. gov.co/relatoria/2003/t-189-03.htm. Corte Constitucional, Sentencia T-510-03, 19 de junio de 2003, magistrado ponente Manuel José Cepeda-Espinosa. Disponible en: http://www.corteconstitucional.gov.co/relatoria/2003/t-510-03.htm. Corte Constitucional, Sentencia T-864-05, 18 de agosto de 2005, magistrado ponente Álvaro Tafur-Galvis. Disponible en: http://www. corteconstitucional.gov.co/relatoria/2005/t-864-05.htm. Corte Constitucional, Sentencia T-551-06, 13 de julio de 2006, magistrado ponente Marco Gerardo Monroy-Cabra. Disponible en: http://www.corteconstitucional.gov.co/relatoria/2006/t-551-06.htm. Corte Constitucional, Sentencia T-078-10, 11 de febrero de 2010, magistrado ponente Luis Ernesto Vargas-Silva. Disponible en: http://www.corteconstitucional.gov.co/relatoria/2010/t-078-10.htm

178 Corte Constitucional, Sentencia T-408-95, 12 de septiembre de 1995, magistrado ponente Eduardo Cifuentes-Muñoz. Disponible en: http://www.corteconstitucional.gov.co/ relatoria/1995/t-408-95.htm. En esta sentencia, la Corte decidió conceder el amparo solicitado por una abuela materna en nombre de su nieta, para que se le garantizara a esta el derecho a visitar a su madre recluida en prisión, pese a la oposición del padre.

179 Corte Constitucional, Sentencia T-078-10, 11 de febrero de 2010, magistrado ponente Luis Ernesto 
De este modo, la jurisprudencia de la Corte Constitucional ha decantado parámetros generales que permiten establecer criterios claros para el análisis de determinadas circunstancias en que el derecho de un niño se vea comprometido. Así estableció, en consecuencia, dos condiciones a verificar: las i) fácticas: "circunstancias específicas del caso, visto en su totalidad y no atendiendo a aspectos aislados" y las (ii) jurídicas: prevén "los parámetros y criterios establecidos por el ordenamiento jurídico para promover el bienestar infantil" 180 .

Las sentencias T-510-03 y T-397-04, reiteradas a su vez por las sentencias T-808-06 y T-078-10 ${ }^{181}$, señalan que hay diversos criterios para determinar el interés superior del menor en los casos concretos, teniendo en cuenta la situación particular del niño.

\section{B. Reconocimiento de derechos innominados e interpretación ampliada de derechos}

La integración y movilidad de los derechos innominados mediante la cláusula del artículo 94, se ha realizado a la luz de los tratados internacionales que componen el bloque de constitucionalidad en sentido estricto y lato. Así puede observarse que en una primera etapa, la Corte Constitucional amplió el alcance del bloque de constitucionalidad, a la luz de los tratados internacionales y con base en ello, ha reconocido derechos. Este artículo es una cláusula abierta de la Constitución que expresa que "la enunciación de los derechos y garantías contenidos en la Constitución y en los conve-

Vargas-Silva. Disponible en: http://www.corteconstitucional.gov.co/relatoria/2010/t-078-10.htm 180 Corte Constitucional, Sentencia T-510-93, 8 de noviembre de 1993, magistrado ponente Vladimiro Naranjo-Mesa. Disponible en: http://www.corteconstitucional.gov.co/ relatoria/1993/t-510-93.htm, citada en pie de página de la sentencia T-078-10. Corte Constitucional, Sentencia T-078-10, 11 de febrero de 2010, magistrado ponente Luis Ernesto VargasSilva. Disponible en: http://www.corteconstitucional.gov.co/relatoria/2010/t-078-10.htm

181 Sentencias T-510-03 y T-397-04, reiteradas a su vez por las sentencias T-808-06 y T-07810. Corte Constitucional, Sentencia T-510-03, 19 de junio de 2003, magistrado ponente Manuel José Cepeda-Espinosa. Disponible en: http://www.corteconstitucional.gov.co/ relatoria/2003/t-510-03.htm. Corte Constitucional, Sentencia T-397-04, 29 de abril de 2004, magistrado ponente Manuel José Cepeda-Espinosa. Disponible en: http://www.corte constitucional.gov.co/relatoria/2004/t-397-04.htm. Corte Constitucional, Sentencia T-808-06, 28 de septiembre de 2006, magistrado ponente Manuel José Cepeda-Espinosa. Disponible en: http://www.corteconstitucional.gov.co/relatoria/2006/t-808-06.htm. Corte Constitucional, Sentencia T-078-10, 11 de febrero de 2010, magistrado ponente Luis Ernesto Vargas-Silva. Disponible en: http://www.corteconstitucional.gov.co/relatoria/2010/t-078-10.htm 
nios internacionales vigentes, no debe entenderse como negación de otros que, siendo inherentes a la persona humana, no figuren expresamente en ellos". La ampliación de la interpretación de derechos existentes y los derechos innominados se puede explicar por un tipo de interpretación evolutiva y dinámica ${ }^{182}$ de la Corte con base en el bloque de constitucionalidad, como se describe a continuación.

Así en situaciones de vulneración de la dignidad, integridad, en casos en los que no puede establecerse el derecho que se ha vulnerado y ampararlo mediante la acción de tutela, la Corte reconoció el derecho al mínimo vital y móvil (T-426-92) ${ }^{183}$; el derecho a la identidad sexual del niño (T-477-95) ${ }^{184}$; en la sentencia C-578-95185 sostuvo que una orden en las fuerzas militares que atente contra los derechos intangibles no debe ser ejecutada. En la sentencia C$355-06^{186}$ reguló los derechos sexuales y reproductivos de la mujer; T-459-9 ${ }^{187}$ el derecho a la tranquilidad; C-370-0 $6^{188}$ sobre los derechos fundamentales de las víctimas a la verdad, justicia, reparación y no repetición. El derecho a morir en forma digna $(C-239-97)^{189}$. El

182 JAVIER García-Roca, Del diálogo entre los tribunales constitucionales y las cortes supranacionales de derechos: algunas cuestiones para disputar, en Jurisdicción de la libertad en Europa e Iberoamérica, 121-164 (Raúl CAnosa-Usera \& Jaime Rodríguez-Arana Muñoz, coords., Editorial Reus, Madrid, 2014).

183 Corte Constitucional, Sentencia T-426-92, 24 de junio de 1992, magistrado ponente Eduardo Cifuentes-Muñoz. Disponible en: http://corteconstitucional.gov.co/relatoria/1992/t-426-92.htm

184 Corte Constitucional, Sentencia T-477-95, 23 de octubre de 1995, magistrado ponente Alejandro Martínez-Caballero. Disponible en: http://www.corteconstitucional.gov.co/ relatoria/1995/t-477-95.htm

185 Corte Constitucional, Sentencia C-578-95, 4 de diciembre de 1995, magistrado ponente Eduardo Cifuentes-Muñoz. Disponible en: http://corteconstitucional.gov.co/relatoria/1995/c-578-95.htm

186 Corte Constitucional, Sentencia C-355-06, 10 de mayo de 2006, magistrados ponentes Jaime Araújo-Rentería, Clara Inés Vargas-Hernández. Disponible en: http://www.corteconstitucional.gov.co/relatoria/2006/c-355-06.htm

187 Corte Constitucional, Sentencia T-459-98, 2 de septiembre de 1998, magistrado ponente Vladimiro Naranjo-Mesa. Disponible en: http://www.corteconstitucional.gov.co/ relatoria/1998/t-459-98.htm

188 Corte Constitucional, Sentencia C-370-06, 18 de mayo de 2006, magistrados ponentes Manuel José Cepeda-Espinosa, Jaime Córdoba-Triviño, Rodrigo Escobar-Gil, Marco Gerardo Monroy-Cabra, Álvaro Tafur-Galvis, Clara Inés Vargas-Hernández. Disponible en: http:// www.corteconstitucional.gov.co/relatoria/2006/c-370-06.htm

189 Corte Constitucional, Sentencia C-239-97, 20 de mayo de 1997, magistrado ponente Carlos GaviriaDíaz. Disponible en: http://www.corteconstitucional.gov.co/relatoria/1997/c-239-97.htm 
derecho al olvido, sentencia C-1066-02 ${ }^{190}$ 191 . La sentencia T-859-03 ${ }^{192}$ que reconoce el derecho a la salud como derecho fundamental, de manera autónoma, cuando se puede concretar en una garantía subjetiva derivada de las normas que rigen el derecho a la salud, advirtiendo que algunas de estas están en la Constitución misma, otras en el bloque de constitucionalidad y la mayoría, finalmente, en las leyes y demás normas que crean y estructuran el Sistema Nacional de Salud.

Ahora bien, respecto a la protección a la maternidad en el período comprendido entre 1992 y 1997, la Corte Constitucional se pronunció de manera reiterada sobre el derecho a la estabilidad laboral de la mujer en estado de embarazo como un derecho fundamental, y acerca de la procedencia de la acción de tutela como mecanismo transitorio frente a casos de despidos de mujeres por causa del embarazo ${ }^{193}$. Ello obligó a que el amparo, el reintegro y el

190 Corte Constitucional, Sentencia C-1066-02, 3 de diciembre de 2002, magistrado ponente Jaime Araújo-Rentería. Disponible en: http://www.corteconstitucional.gov.co/ relatoria/2002/c-1068-02.htm

191 La relación de sentencias se encuentra en el artículo de Vicente F. Benítez-R, Legitimidad democrática y constitucional de las modificaciones implicitas a la Constitución por parte de la jurisprudencia constitucional en Colombia, 122 Vniversitas, 303-334 (2011). Disponible en: http:// revistas.javeriana.edu.co/index.php/vnijuri/article/view/14345. Es importante en este punto señalar que no estoy de acuerdo con la tesis del autor que se refiere a estas sentencias como una mutación constitucional. El reconocimiento de derechos que estas sentencias refieren se realiza en el marco del artículo 94 y en la interpretación de la Corte sobre el bloque de constitucionalidad en sentido estricto, lo que permite aplicar estos derechos a controversias concretas.

192 Corte Constitucional, Sentencia T-859-03, 25 de septiembre de 2003, magistrado ponente Eduardo Montealegre-Lynett. Disponible en: http://www.corteconstitucional.gov.co/ relatoria/2003/t-859-03.htm

193 Entre otras, Corte Constitucional, Sentencia T-375-00, 30 de marzo de 2000, magistrado ponente Vladimiro Naranjo-Mesa. Disponible en: http://www.corteconstitucional.gov.co/ relatoria/2000/t-375-00.htm. Corte Constitucional, Sentencia T-911-00, 17 de julio de 2000, magistrado ponente Alejandro Martínez-Caballero. Disponible en: http://www.corteconstitucional. gov.co/relatoria/2000/t-911-00.htm. Corte Constitucional, Sentencia T-934-00, 24 de julio de 2000, magistrado ponente Alejandro Martínez-Caballero. Disponible en: http://www.corteconstitucional.gov.co/relatoria/2000/t-934-00.htm. Corte Constitucional, Sentencia T-1247-00, 7 de septiembre de 2000, magistrado ponente Alejandro Martínez-Caballero. Disponible en: http:// www.corteconstitucional.gov.co/relatoria/2000/t-1247-00.htm. Corte Constitucional, Sentencia T-1558-00, 21 de noviembre de 2000, magistrado ponente Fabio Morón-Díaz. Disponible en: http://www.corteconstitucional.gov.co/relatoria/2000/t-1558-00.htm. Corte Constitucional, Sentencia T-040A-01, 22 de enero de 2001, magistrado ponente Fabio Morón-Díaz. Disponible en: http://corteconstitucional.gov.co/relatoria/2001/T-040A-01.htm. Corte Constitucional, Sentencia T-367-01, 3 de abril de 2001, magistrado ponente Jaime Araújo-Rentería. Disponible en: http://corteconstitucional.gov.co/relatoria/2001/t-367-01.htm. Corte Constitucional, Sentencia T-664-01, 27 de junio de 2001, magistrado ponente Jaime Araújo-Rentería. Disponible en: http://corteconstitucional.gov.co/relatoria/2001/t-664-01.htm. Corte Constitucional, Sentencia T-697-01, 5 de julio de 2001, magistrado ponente Álvaro Tafur-Galvis. Disponible en: 
reconocimiento de indemnizaciones se estructuraran desde la interpretación sistémica de los artículos 13, 43 y 53 de la Constitución, vía acción de tutela. Así, la igualdad que garantiza la no discriminación de la mujer, la especial protección del Estado durante el embarazo y después del parto y la protección del nasciturus como expresiones del respeto y el amparo a la vida y al menor, fueran materializadas en concordancia y aplicación de las normas internacionales como el Convenio OIT $3^{194}$ relativo al empleo de las mujeres antes y después del parto (artículo 4) ${ }^{195}$.

Esta ampliación de la Carta en materia de derechos en desarrollo de la cláusula abierta también ha tenido una importancia social y protección a población vulnerable por razones de sus condiciones de sexo, raza u orientación sexual. Así, la Corte ha reconocido y protegido la no discriminación de los derechos de los homosexuales como individuos y los reconocimientos de derechos sociales tales como salud y pensión en los casos en que conformen una pareja ${ }^{196}$. Frente al primero, la Corte protege el derecho a la orientación sexual diversa en el marco de un estado liberal y democrático como el colombiano. En ese sentido, condena todo acto de discriminación que se relacione con la orientación sexual por ser inconstitucional. Respecto del segundo, reconoce en la sentencia C-098-96 ${ }^{197}$ las uniones del mismo sexo. En sentencias posteriores como la C-075-07198

http://corteconstitucional.gov.co/relatoria/2001/t-697-01.htm. Corte Constitucional, Sentencia T-1040-01, 27 de septiembre de 2001, magistrado ponente Rodrigo Escobar-Gil. Disponible en: http://corteconstitucional.gov.co/relatoria/2001/t-1040-01.htm. Corte Constitucional, Sentencia T-161-02, 7 de marzo de 2002, magistrado ponente Álvaro Tafur-Galvis. Disponible en: http:// corteconstitucional.gov.co/relatoria/2002/t-161-02.htm. Corte Constitucional, Sentencia T-90004, 16 de septiembre de 2004, magistrado ponente Jaime Córdoba-Triviño. Disponible en: http:// corteconstitucional.gov.co/relatoria/2004/t-900-04.htm

194 Organización Internacional del Trabajo, OIT, Convenio OIT 3, sobre la protección de la maternidad, Washington, 29 de noviembre de 1919. Disponible en: http://www.ilo.org/dyn/ normlex/es/f?p=NORMLEXPUB:12100:0::NO::P12100_ILO_CODE:C003

195 Sentencia C-225-95 en lo atinente al bloque de constitucionalidad y en especial los artículos 23 y 25 de la Declaración Universal de Derechos Humanos (1948), artículos 7 y 8 de la Declaración Americana de los Derechos y Deberes del Hombre, de 1948, entre otros. Corte Constitucional, Sentencia C-225-95, 18 de mayo de 1995, magistrado ponente Alejandro Martínez-Caballero. Disponible en: http://corteconstitucional.gov.co/relatoria/1995/c-225-95.htm

196 Alejandra Azuero-Quijano, Sentencia C-075 de 2007. Reconocimiento jurídico de las parejas del mismo sexo en Colombia, en Activismo judicial y derechos de los LGTB en Colombia: sentencias emblemáticas, 11-35 ( $1^{\text {a }}$ ed., Alejandra Azuero-Quijano \& Mauricio AlbarracínCABALlero, eds., Instituto Latinoamericano de Servicios Legales Alternativos, ILSA, Bogotá, 2009). Disponible en: http://ilsa.org.co:81/biblioteca/dwnlds/dyj/dyj10/dyj10-aleja.pdf

197 Corte Constitucional, Sentencia C-098-96, 7 de marzo de 1996, magistrado ponente Eduardo Cifuentes-Muñoz. Disponible en: http://corteconstitucional.gov.co/relatoria/1996/c-098-96.htm

198 Corte Constitucional, Sentencia C-075-07, 7 de febrero de 2007, magistrado ponente Rodrigo 
iguala los derechos de las parejas heterosexuales a las parejas del mismo sexo. Y en la sentencia C-577-11 ${ }^{199}$ señala la revisión del artículo 113 del Código Civil ${ }^{200}$ respecto del matrimonio de parejas del mismo sexo.

Respecto de la introducción de nuevos derechos mediante jurisprudencia, como un bloque de constitucionalidad de derechos, es de destacar que esto ha ampliado su concepción formal, lo que permite acentuar la base racional normativa de la Constitución de 1991 y su modelo liberal democrático ${ }^{201}$. En este sentido, han tenido lugar importantes debates sobre la igualdad, los derechos de las víctimas; la protección de los derechos sociales como el mínimo vital y móvil, la salud, la protección al medio ambiente sano cuando la industria extractiva vulnera los derechos al territorio, acceso al agua ${ }^{202}$.

Puede señalarse que los problemas más importantes del Estado están siendo discutidos en sede de la Corte y en el mismo se define cómo se materializan los tratados internacionales en derechos humanos frente a las tensiones en políticas de desarrollo, de empleo, de salud, de educación. La alta conflictividad en materia de tutela permite evidenciar que estas discusiones están teniendo lugar por la vía jurídica y se ponen en cuestionamiento las concepciones de

Escobar-Gil. Disponible en: http://corteconstitucional.gov.co/relatoria/2007/c-075-07.htm

199 Corte Constitucional, Sentencia C-577-11, 26 de julio de 2011, magistrado ponente Gabriel Eduardo Mendoza-Martelo. Disponible en: http://corteconstitucional.gov.co/ relatoria/2011/c-577-11.htm

200 Colombia, Ley 57 de 1887, Código Civil. Disponible en: http://www.secretariasenado.gov.co/ senado/basedoc/codigo_civil.html

201 Daniel Bonilla \& Isabel Cristina Jaramillo, El igualitarismo liberal de Dworkin, Introducción, en La comunidad liberal, 11-132, 27-35 (Ronald Dworkin, Siglo del Hombre Editores, Universidad de los Andes, Facultad de Derecho, Bogotá, 1996).

202 Corte Constitucional, Sentencia C-671-01, 28 de junio de 2001, magistrado ponente Jaime Araújo-Rentería. Disponible en: http://corteconstitucional.gov.co/relatoria/2001/c-671-01. htm. Corte Constitucional, Sentencia T-411-92, 17 de junio de 1992, magistrado ponente Alejandro Martínez-Caballero. Disponible en: http://www.corteconstitucional.gov.co/ relatoria/1992/t-411-92.htm. Corte Constitucional, Sentencia T-092-93, 19 de febrero de 1993, magistrado ponente Simón Rodríguez-Rodríguez. Disponible en: http://corteconstitucional. gov.co/relatoria/1993/t-092-93.htm. Corte Constitucional, Sentencia T-254-93, 30 de junio de 1993, magistrado ponente Antonio Barrera-Carbonell. Disponible en: http://corteconstitucional.gov.co/relatoria/1993/t-254-93.htm. Corte Constitucional, Sentencia T-004-95, 16 de enero de 1995, magistrado ponente José Gregorio Hernández-Galindo. Disponible en: http:// corteconstitucional.gov.co/relatoria/1995/t-004-95.htm. Corte Constitucional, Sentencia T-046-99, 29 de enero de 1999, magistrado ponente Hernando Herrera-Vergara. Disponible en: http://corteconstitucional.gov.co/relatoria/1999/t-046-99.htm. Corte Constitucional, Sentencia T-749-14, 8 de octubre de 2014, magistrado ponente Jorge Iván Palacio-Palacio. Disponible en: http://corteconstitucional.gov.co/relatoria/2014/t-749-14.htm 
la diversidad y la pluralidad de la Constitución, así como su relación con el debate constitucional multinivel y su integración en los escenarios internos. 


\section{CONCLUSIONES}

Si bien el contenido del bloque de constitucionalidad varía de país en país o es una expresión del tiempo-lugar en que la figura de la interpretación es adaptada por los tribunales constitucionales y la doctrina, se observa la adopción del pluralismo constitucional, trabajo en red y con ello, la interpretación horizontal. Para el caso colombiano, la solución de controversias respecto a derechos humanos no solo atañe a las normas constitucionales, sino a los tratados internacionales y a los fallos de la Corte Interamericana de Derechos Humanos. El sistema de fuentes se ha ampliado con la integración de normas al bloque, y la interpretación respecto de las normas constitucionales y las internacionales se suele hacer mediante normas de reenvío o de integración que permiten realizar estas interpretaciones horizontales. Así mismo, se presenta un diálogo entre las Cortes nacionales e internacionales de multinivel. Estos cambios permiten comprender cómo las constituciones están adoptando mecanismos para ser más dinámicas y evolutivas en sus interpretaciones con el fin de acercar el texto constitucional a las necesidades de los individuos. También puede evidenciarse el conflicto y las tensiones existentes en los modelos liberales y democráticos contemporáneos.

El caso colombiano es interesante para América Latina, por ser un Estado en el que ha tenido lugar un largo conflicto armado cuyo reto es la materialización de los derechos. Así también ha operado un cambio en la estructura del poder en la Constitución que se materializa en la ampliación de la Carta y en la interrelación, al menos desde la sede constitucional, con las cortes internacionales. Se evidencian de acuerdo a las sentencias estudiadas en este artículo problemas de inequidad entre territorios, el acceso a tierras; el modelo económico de desarrollo y la diversidad étnica; la capacidad del Estado para responder frente a un derecho a la salud universal y de calidad; el reconocimiento a la diversidad étnica y sexual. Los pronunciamientos de la Corte Constitucional que se han reseñado en este artículo muestran estas tensiones y cómo a pesar de ello se han ampliado derechos y declarado normas inconstitucionales cuando violan el bloque de constitucionalidad. Sin embargo, también hay dificultades en las precisiones del bloque, 
los pronunciamientos de la Corte generan ambigüedades respecto a qué integra esta figura; esto se observa en las previsiones como: "hace parte tácitamente del bloque" o hace parte "indirecta del bloque"; las contradicciones entre las sentencias y los cambios de línea jurisprudencial sin la suficiente justificación.

Se observa un proceso muy lento de asimilación del bloque por parte de los jueces y, por ello, no extensivo el lenguaje de los derechos humanos ${ }^{203}$. Así también, se observa que los trabajos doctrinales deben acompañar este proceso de manera más directa en la ayuda de la sistematización y teorización de los cambios que están teniendo lugar. De este modo, se puede comprender por los diversos operadores judiciales la necesidad de la aplicación directa de los tratados internacionales y la jurisprudencia relacionada de la Corte Interamericana y Constitucional como criterio hermenéutico relevante para amparar los derechos y resolver algunas de las tensiones de un Estado liberal contemporáneo.

203 A esta conclusión se llega por el número de sentencias en revisión en las que no se tutelan los derechos solicitados. 


\section{BIBLIOGRAFÍA}

\section{Libros}

Bustos-Gisbert, Rafael, La Constitución Red: un estudio sobre supraestatalidad y Constitución (Instituto Vasco de Administración Pública, Oñati, 2005).

Colombia, Centro Nacional de Memoria Histórica, ;Basta ya! Colombia: Memorias de guerra y dignidad (Centro Nacional de Memoria Histórica, Imprenta Nacional, Bogotá, 2013). Disponible en: http://www.centrodememoriahistorica.gov.co/ micrositios/informeGeneral/descargas.html

Dworkin, Ronald, La comunidad liberal (Siglo del Hombre Editores, Universidad de los Andes, Facultad de Derecho, Bogotá, 1996).

ElazAR, DANiEL J., Exploring Federalism (The University of Alabama Press, Tuscaloosa, London, 1991).

Elazar, Daniel J., Federal Systems of the World, A Handbook of Federal, Confederal and Autonomy Arrangements (Jerusalem Institute for Federal Studies, Longman Group, Harlow, Essex, United Kingdom, 1991).

Favoreu, Louis \& Philip, Loïc, Les grandes décisions du Conseil Constitutionnel (Sirey, Paris, 1986).

García de Enterría, EduArdo, Sobre el modelo autonómico español y sobre las actuales tendencias federalistas, en La revisión del sistema de autonomías territoriales: reforma de estatutos, leyes de transferencia y delegación, federalismo (Civitas, Madrid, 1988). Texto disponible en: http://www.cuentayrazon.org/revista/ pdf/030/Num030_002.pdf

GonzÁlez-Jácome, Jorge, Estados de excepción democracia liberal en América del Sur: Argentina, Chile y Colombia (1930-1990) (Pontificia Universidad Javeriana, Bogotá, 2015).

Häberle, Peter, Pluralismo y Constitución: estudios de teoría constitucional de la sociedad abierta (Emilio Mikunda-Franco, trad., Tecnos, Madrid, 2002).

Kelsen, Hans, ¿Quién debe ser el defensor de la Constitución? (Tecnos, Madrid, 19311995) [Wer soll Hüter der Verfassung sein?, 6 Die Justiz, 576-628 (1931)].

Moreno-Fernández, Luis, La federalización de España. Poder político y territorio (Siglo XXI Editores, Madrid, 1997).

Moyn, Samuel, The Last Utopia. Human Rights in History (Harvard University Press, Cambridge, Massachusetts, 2012).

Otto y Pardo, Ignacio de, Estudios sobre derecho estatal y autonómico (Editorial Civitas, Madrid, 1986).

Rubio-Llorente, Francisco, La forma del poder. Estudio sobre la Constitución (Centro de Estudios Políticos y Constitucionales, Madrid, 1993).

Suelt-Cock, Vanessa, Federalismo en teoría y práctica - El caso español como proceso federal - Estudio de la autonomía regional y local en los sistemas federales (Juruá Editora, Curitiba, Brasil, 2010). 
TOMÁs y VAliente, Francisco, El reparto competencial en la jurisprudencia del Tribunal Constitucional (Tecnos, Madrid, 1988).

\section{Colaboración en obras colectivas}

Aja-Fernández, Eliseo \& González-Beilfuss, Markus, Conclusiones generales, en Las tensiones entre el Tribunal Constitucional y el Legislador en la Europa actual, 266272 (Eliseo Aja-FernándeZ, ed., Editorial Ariel, Barcelona, 1998).

Azuero-Quijano, Alejandra, Sentencia C-075 de 2007. Reconocimiento jurídico de las parejas del mismo sexo en Colombia, en Activismo judicial y derechos de los LGTB en Colombia: sentencias emblemáticas, 11-35 ( $1^{\text {a }}$ ed., Alejandra AzueroQuijano \& Mauricio Albarracín-Caballero, eds., Instituto Latinoamericano de Servicios Legales Alternativos, ILSA, Bogotá, 2009). Disponible en: http:// ilsa.org.co:81/biblioteca/dwnlds/dyj/dyj10/dyj10-aleja.pdf

Bonilla, Daniel \& Jaramillo, Isabel Cristina, El igualitarismo liberal de Dworkin, Introducción, en La comunidad liberal, 11-132 (RonAld Dworkin, Siglo del Hombre Editores, Universidad de los Andes, Facultad de Derecho, Bogotá, 1996).

Canosa-Usera, Raúl, Interpretación evolutiva de los derechos fundamentales, en La ciencia del derecho procesal constitucional. Estudios en homenaje a Héctor FixZamudio en sus cincuenta años como investigador del derecho, T. VI, Interpretación constitucional y jurisdicción electoral, Capítulo XV, Interpretación y argumentación constitucional, 57-98 (Eduardo Ferrer-MaC-Gregor \& Arturo Zaldívar-Lelo DE LARREA, coords., Instituto de Investigaciones Jurídicas de la Universidad Nacional Autónoma de México, UNAM, México, 2013). Disponible en: http:// bibliohistorico.juridicas.unam.mx/libros/6/2560/8.pdf, http://bibliohistorico. juridicas.unam.mx/libros/libro.htm?l=2560

FAVoreu, Louis, American and European Models of Constitutional Justice, en Comparative and Private International Law: Essays in honor of John Henry Merryman on his Seventieth Birthday, 105-120 (David S. Clark, ed., Duncker \& Humblot, Berlin, 1990).

FAVOREU, LouIs, Le principe de constitutionnalité: essai de définition d'après la jurisprudence $d u$ Conseil constitutionnel, en Recueil d'études en hommage à Charles Eisenmann, 33-48 (Mélanges, Éditions Cujas, Paris, 1975).

Favoreu, Louis \& Rubio-Llorente, Francisco, Bloque de constitucionalidad (Derecho Constitucional), en Enciclopedia Jurídica Básica, t. 1 (Civitas, Madrid, 1995).

García-Roca, Javier, Del diálogo entre los tribunales constitucionales y las cortes supranacionales de derechos: algunas cuestiones para disputar, en Jurisdicción de la libertad en Europa e Iberoamérica, 121-164 (RAúl CANOSA-USERA \& JAIME Rodríguez-Arana MuÑoz, coords., Editorial Reus, Madrid, 2014).

Guastini, Riccardo, La Costituzione come limite alla legislazione, en Analisi e diritto 1998. Ricerche di giurisprudenza analitica, 107-114 (Paolo ComanducCi \& Riccardo Guastini, eds., Giappichelli Editore, Torino, 1998).

Jaramillo-Jaramillo, Carlos Ignacio, Hacia una jurisprudencia racional. $Y$ relativamente vinculante. Observaciones y reparos al 'precedente obligatorio', en El precedente judicial en Colombia: papel y valor asignados a la jurisprudencia 
(Javier Tamayo-Jaramillo \& Carlos Ignacio Jaramillo-Jaramillo, Ibáñez, Pontificia Universidad Javeriana, Bogotá, 2012).

Linz, Juan José, De la crisis de un Estado unitario al Estado de las Autonomías, en La España de las Autonomías, 527-672 (Fernando Fernández-Rodríguez, ed., Instituto de Estudios de Administración Local, Ministerio de Administración Territorial, Madrid, 1985).

Lojendio e Irure, Ignacio María, Autonomía y consenso, en Federalismo y regionalismo, 51-86 (Gumersindo Trujlllo, coordinación y presentación, Centro de Estudios Constitucionales, Madrid, 1979).

López-Garrido, Diego; Massó-Garrote, Marcos Francisco \& Pegoraro, Lucio, dirs., El Estado Autonómico como variante del Estado compuesto, en Nuevo Derecho Constitucional Comparado, capítulo decimotercero, 565-672 (Tirant lo Blanch, Valencia, 2000).

López-Guerra, Luis María, La función constitucional y el contenido del Estatuto de Autonomía, en Estudios sobre la reforma del Estatuto (CARles Viver I Pi Sunyer, ed., Generalitat de Catalunya, Institut d'Estudis Autonòmics, IEA, Barcelona, 2004).

Maduro-Poiares, Miguel, Three Claims of Constitutional Pluralism, en Constitutional Pluralism in the European Union and Beyond, 67-84 (Matej Avbelu \& JAN KomÁrek, eds., Hart Publishing, Oxford, Portland, 2012). Texto disponible en: https://www.wzb.eu/sites/default/files/veranstaltungen/the-promise-ofconstitutional-pluralism/miguelmadurothreeclaimsofconstitutionalpluralism hu-collmay152012.pdf

Tornos, Joaquín, La organización territorial del Estado español: el Estado de las Autonomías, en El federalismo en Europa, 143-166 (Thomas Fleiner-Gerster, Dieter Grimm, Heinz Schäffer, Francis Delpérée \& Joaquín Tornos, Hacer, Barcelona, 1993).

Uprimny-Yepes, Rodrigo, El bloque de constitucionalidad en Colombia. Un análisis jurisprudencial y un ensayo de sistematización doctrinal, en Compilación de jurisprudencia y doctrina nacional e internacional, vol. I, 1-35 (Oficina en Colombia del Alto Comisionado de las Naciones Unidas para los Derechos Humanos, Bogotá, 2001).

\section{Revistas}

Arango-Olaya, Mónica, El bloque de constitucionalidad en la jurisprudencia de la Corte Constitucional colombiana, 2004 Precedente, Revista Jurídica, 79-102 (2004). Disponible en: http://www.icesi.edu.co/contenido/pdfs/C1C-marango-bloque.pdf

BARQue, FrançoIs, El principio de sinceridad presupuestaria en Francia: de la esperanza al desengaño, 95 Revista Española de Derecho Constitucional, 203-214 (mayo-agosto 2012). Disponible en: https://dialnet.unirioja.es/descarga/articulo/4002085.pdf

Benítez-R, Vicente F., Legitimidad democrática y constitucional de las modificaciones implícitas a la Constitución por parte de la jurisprudencia constitucional en Colombia, 122 Vniversitas, 303-334 (2011). Disponible en: http://revistas.javeriana. edu.co/index.php/vnijuri/article/view/14345 
Bustos-Gisbert, RAFAel, Las tensiones del Estado autonómico ante el proceso de reforma estatutaria, Revista Jurídica de Castilla y León. Número Extraordinario: La Reforma de los Estatutos de Autonomía, 69-87 (2004). Disponible en: http://www. jcyl.es/web/jcyl/binarios/674/623/Estats09-R.Bustos.pdf?blobheader=applicatio $\mathrm{n} \% 2$ Fpdf $\% 3$ Bcharset $\% 3$ DUTF-8

CARPIO-MARCos, ÉDGAR, Bloque de constitucionalidad y proceso de inconstitucionalidad de las leyes, 4 Revista Iberoamericana de Derecho Procesal Constitucional, 79114 (2005). Disponible en: https://works.bepress.com/edgar_carpio_marcos/1/

Fajardo-Arturo, Luis Andrés, Contenido y alcance jurisprudencial del bloque de constitucionalidad en Colombia, 7 Civilizar, Ciencias Sociales y Humanas, 13, 1534 (julio-diciembre de 2007). Disponible en: http://repository.usergioarboleda. edu.co/bitstream/handle/11232/352/CienciasSocialesyHumanas7133.pdf;jsessio nid=6F155E70FDCEAD4A48B39639344BC68D?sequence $=1$

García-Roca, Javier, El diálogo entre el Tribunal Europeo de Derechos Humanos y los tribunales constitucionales en la construcción de un orden público europeo, 30 Teoría y Realidad Constitucional, 183-224 (2012). Disponible en: http://revistas. uned.es/index.php/TRC/article/view/7005/6703

Glendon, Mary Ann, Rights in Twentieth-Century Constitutions, 59 The University of Chicago Law Review, 1, The Bill of Rights in the Welfare State: A Bicentennial Symposium, held at The University of Chicago Law School on October 25-26, 1991, 519-538 (1992). Disponible en: http://chicagounbound.uchicago.edu/cgi/ viewcontent.cgi? article $=4760 \&$ context $=u c l r e v$

Gómez-FernÁNDEZ, ItZiar, Redefinir el bloque de la constitucionalidad 25 años después, 54 Estudios de Deusto, 1, 61-98 (Bilbao, enero-junio 2006). Disponible en: http:// revista-estudios.revistas.deusto.es/article/view/425/587

Kincaid, John, State Constitutions in the Federal System, 496 The Annals of The American Academy of Political and Social Science, AAAPSS, 12-22 (1988).

LóPez-Medina, Diego Eduardo \& Sánchez-Mejía, Astrid Liliana, La armonización del derecho internacional de los derechos humanos con el derecho penal colombiano, 6 International Law: Revista Colombiana de Derecho Internacional, ILDI, 12, 317-352 (Edición Especial: 60 Años de la Declaración Universal de Derechos Humanos y 30 años de entrada en vigencia de la Convención Americana de Derechos Humanos, 2008). Disponible en: http://revistas.javeriana.edu.co/index. php/internationallaw/article/view/13929/11217

LóPEZ-Ruiz, Francisco, Los conceptos de 'todo' y 'parte' aplicado al estudio de los estados compuestos, 17 Revista Española de Derecho Constitucional, 49, 145-167 (1997). Disponible en: https://dialnet.unirioja.es/descarga/articulo/79577.pdf

MacCormick, Neil, Beyond the Sovereign State, 56 The Modern Law Review, 1, 1-18 (1993). Disponible en: http://onlinelibrary.wiley.com/doi/10.1111/j.1468-2230.1993. tb02851.x/epdf

Pacteau, Bernard, Duguit ;El Estado Reencontrado!, 185 Revista de Administración Pública, 345-363 (mayo-agosto 2011). Disponible en: https://dialnet.unirioja.es/ descarga/articulo/3732694.pdf

Ramelli, Alejandro, Sistema de fuentes del derecho internacional público y 'bloque de constitucionalidad' en Colombia, 11 Cuestiones Constitucionales, 157-175 
(julio-diciembre de 2004). Disponible en http://www.redalyc.org/articulo. oa? $\mathrm{id}=88501105$

Solozábal-Echavarría, Juan José, El estado autonómico en perspectiva, 124 Revista de Estudios Politicos (Nueva Época), 9-28 (abril-junio 2004). Disponible en: https:// dialnet.unirioja.es/descarga/articulo/968174.pdf

Wieacker, Franz \& Bodenheimer, Edgar, trad., Foundations of European Legal Culture, 38 The American Journal of Comparative Law, 1, 1-29 (Winter, 1990).

\section{Working paper}

Pernice, Ingolf \& Mayer, Franz C., De la Constitution composée de l'Europe, 1-27 (Walter Hallstein Institut für Europäisches Verfassungsrecht, WHI, 1/2001)). Disponible en: http://www.whi-berlin.eu/documents/whi-paper0101.pdf

\section{Cursos, documentos, informes, ponencias, reportes}

Organización de Naciones Unidas, ONU, Comité de Derechos Económicos, Sociales y Culturales, CESCR, Folleto informativo No. 16 (Rev. 1) (Oficina del Alto Comisionado de las Naciones Unidas para los Derechos Humanos, OACNUDH, Ginebra, 1996). Disponible en: http://www.ohchr.org/Documents/Publications/ FactSheet16Rev.1sp.pdf

Organización de Naciones Unidas, ONU, Informe del representante especial del secretario general de Naciones Unidas para el tema de los Desplazamientos Internos de Personas, Sr. Francis Deng, Doc. E/CN.4/1998/53/Add.2, 11 de febrero de 1998. Disponible en: http://www.hchr.org.co/documentoseinformes/ documentos/html/informes/onu/resdi/E-CN-4-1998-53-ADD-2.html

Organización Internacional del Trabajo, OIT, Comité de Libertad Sindical, Informe provisional, Informe 309, Ginebra, marzo de 1998. Disponible en: http:// www.ilo.org/dyn/normlex/es/f?p=NORMLEXPUB:50002:0::NO::P50002_ COMPLAINT_TEXT_ID:2903180

Uprimny-Yepes, Rodrigo, El bloque de constitucionalidad en Colombia. Un análisis jurisprudencial y un ensayo de sistematización doctrinal, Curso de formación de promotores/as en derechos humanos, libertad sindical y trabajo decente (Universidad Nacional, Escuela Nacional Sindical, ENS Colombia, Bogotá, 2005). Disponible en: http://redescuelascsa.com/sitio/repo/DJS-Bloque_ Constitucionalidad(Uprimny).pdf

\section{Tratados internacionales}

Comunidad Andina de Naciones, Gobiernos de Bolivia, Colombia, Ecuador, Perú y Venezuela, Tratado Constitutivo del Parlamento Andino, La Paz, 25 de octubre de 1979. Disponible en: http://www.sice.oas.org/Trade/Junac/Parl1979.pdf

Hague Conference on Private International Law, $\mathrm{HCCH}$, Convenio relativo a la Protección del Niño y a la Cooperación en Materia de Adopción Internacional, 
La Haya, 29 de mayo de 1993. Disponible en: https://www.hcch.net/es/ instruments/conventions/specialised-sections/intercountry-adoption, http:// www.oas.org/dil/esp/Convenio_Haya_Proteccion_del_Nino_Cooperacion_en_ Materia_Adopcion_Internacional_Espana.pdf

Organización de Estados Americanos, OEA, Declaración Americana de los Derechos y Deberes del Hombre, Bogotá, 30 de abril de 1948. Disponible en: http://www. oas.org/es/cidh/mandato/Basicos/declaracion.asp

Organización de Estados Americanos, OEA, Convención Americana sobre Derechos Humanos, Pacto de San José, San José, Costa Rica, 7 al 22 de noviembre de 1969. Disponible en: https://www.oas.org/dil/esp/tratados_B-32_Convencion_ Americana_sobre_Derechos_Humanos.htm

Organización de Estados Americanos, OEA, Convención Interamericana para Prevenir, Sancionar y Erradicar la Violencia contra la Mujer, Convención de Belém do Pará, Belém do Pará, 9 de junio de 1994. Disponible en: http://www.oas.org/ juridico/spanish/tratados/a-61.html

Organización de Estados Americanos, OEA, Convención Interamericana sobre Tráfico Internacional de Menores, Ciudad de México, 18 de marzo de 1994. Disponible en: http://www.oas.org/dil/esp/tratados_B-57_Convencion_Interamericana_ sobre_Trafico_Internacional_de_Menores.htm

Organización de Estados Americanos, OEA, Protocolo adicional a la Convención Americana sobre Derechos Humanos en materia de Derechos Económicos, Sociales y Culturales, Protocolo de San Salvador, San Salvador, 17 de noviembre de 1988. Disponible en: http://www.oas.org/juridico/spanish/tratados/a-52.html

Organización de Naciones Unidas, ONU, Convención contra la Tortura y otros Tratos o Penas Crueles, Inhumanos o Degradantes, Asamblea General, Resolución 39/46, 10 de diciembre de 1984. Disponible en: http://www.ohchr.org/SP/ ProfessionalInterest/Pages/CAT.aspx

Organización de Naciones Unidas, ONU, Convención de las Naciones Unidas contra la Delincuencia Organizada Transnacional y sus Protocolos, Asamblea General, Resolución 55/25, 15 de noviembre de 2000. Disponible en: https://www.unodc. org/pdf/cld/TOCebook-s.pdf

Organización de Naciones Unidas, ONU, Convención Internacional sobre la Eliminación de Todas las Formas de Discriminación contra la Mujer, Asamblea General, Resolución 34/180, 18 de diciembre de 1979. http://www.ohchr.org/SP/ ProfessionalInterest/Pages/CEDAW.aspx

Organización de Naciones Unidas, ONU, Convención para la Prevención y la Sanción del Delito de Genocidio, Asamblea General, Resolución 260 A (III), 9 de diciembre de 1948. Disponible en: https://www.icrc.org/spa/resources/documents/misc/ treaty-1948-conv-genocide-5tdm6h.htm

Organización de Naciones Unidas, ONU, Estatuto de Roma de la Corte Penal Internacional, Roma, 17 de julio de 1998. Disponible en: http://www.un.org/ spanish/law/icc/statute/spanish/rome_statute(s).pdf

Organización de Naciones Unidas, ONU, Protocolo para Prevenir, Reprimir y Sancionar la Trata de Personas, especialmente Mujeres y Niños, que complementa la Convención de las Naciones contra la Delincuencia Organizada Transnacional, 
Asamblea General, Resolución 55/25, 15 de noviembre de 2000. Disponible en: https://www.unodc.org/pdf/cld/TOCebook-s.pdf

Organización de Naciones Unidas, ONU, Convención Internacional sobre la Eliminación de Todas las Formas de Discriminación Racial, Asamblea General, Resolución 2106 A (XX), 21 de diciembre de 1965. Disponible en: http://www. ohchr.org/SP/ProfessionalInterest/Pages/CERD.aspx

Organización de Naciones Unidas, ONU, Convención sobre los Derechos del Niño, Asamblea General, Resolución 44/25, 20 de noviembre de 1989. Disponible en: http://www.ohchr.org/SP/ProfessionalInterest/Pages/crc.aspx

Organización de Naciones Unidas, ONU, Declaración Universal de Derechos Humanos, París, 10 de diciembre de 1948. Disponible en: http://www.un.org/es/documents/ udhr/

Organización de Naciones Unidas, ONU, Declaración y Plataforma de Acción de Beijing, Cuarta Conferencia Mundial sobre la Mujer, Beijing, 15 de septiembre de 1995. Disponible en: http://www.unwomen.org/ /media/headquarters/ attachments/sections/csw/bpa_s_final_web.pdf

Organización de Naciones Unidas, ONU, Pacto Internacional de Derechos Civiles y Políticos, Asamblea General, Resolución 2200 A (XXI), 16 de diciembre de 1966. Disponible en: http://www.ohchr.org/SP/ProfessionalInterest/Pages/CCPR.aspx

Organización de Naciones Unidas, ONU, Pacto Internacional de Derechos Económicos, Sociales y Culturales, 16 de diciembre de 1966. Disponible en: http://www.ohchr. org/SP/ProfessionalInterest/Pages/CESCR.aspx

Organización de Naciones Unidas, ONU, Protocolo Facultativo de la Convención sobre la Eliminación de todas las formas de Discriminación contra la Mujer, Asamblea General, Resolución A/54/4, 6 de octubre de 1999. Disponible en: http://www. ohchr.org/SP/ProfessionalInterest/Pages/OPCEDAW.aspx

Organización de Naciones Unidas, ONU, Reglas Mínimas de las Naciones Unidas para la Administración de la Justicia de Menores, Reglas de Beijing, Asamblea General, Resolución 40/33, 28 de noviembre de 1985. Disponible en: http://www. ohchr.org/SP/ProfessionalInterest/Pages/BeijingRules.aspx

Organización de Naciones Unidas, ONU, Conferencia Monetaria y Financiera, Convenio Constitutivo del Fondo Monetario Internacional, FMI, Bretton Woods, New Hampshire, 22 de julio de 1944. Disponible en: https://www.imf. org/external/spanish/pubs/ft/aa/aa.pdf

Organización Internacional del Trabajo, OIT, Convenio OIT 3, sobre la protección de la maternidad, Washington, 29 de noviembre de 1919. Disponible en: http:// www.ilo.org/dyn/normlex/es/f?p=NORMLEXPUB:12100:0::NO::P12100_ILO_ CODE:C003

Organización Internacional del Trabajo, OIT, Convenio OIT 29, sobre el trabajo forzoso, Ginebra, 28 de junio de 1930. Disponible en: http://www.ilo.org/dyn/normlex/ es/f?p=1000:12100:0::NO:12100:P12100_INSTRUMENT_ID:312174

Organización Internacional del Trabajo, OIT, Convenio OIT 87, sobre la libertad sindical y la protección del derecho de sindicación, San Francisco, 9 de julio de 1948. Disponible en: http://www.ilo.org/dyn/normlex/es/f?p=1000:12100:0::NO:12100 :P12100_INSTRUMENT_ID:312232 
Organización Internacional del Trabajo, OIT, Convenio OIT 98, sobre el derecho de sindicación y de negociación colectiva, Ginebra, 1 de julio de 1941. Disponible en: http://www.ilo.org/dyn/normlex/es/f?p=1000:12100:0::NO:12100:P12100_ INSTRUMENT_ID:312243

Organización Internacional del Trabajo, OIT, Convenio OIT 105, sobre la abolición del trabajo forzoso, Ginebra, 25 de junio de 1957. Disponible en: http://www.ilo.org/ dyn/normlex/es/f?p=1000:12100:0::NO:12100:P12100_INSTRUMENT_ID:312250

Organización Internacional del Trabajo, OIT, Convenio OIT 138, sobre la edad mínima, Ginebra, 26 de junio de 1973. Disponible en: http://www.ilo.org/dyn/normlex/ es/f?p=1000:12100:0::NO:12100:P12100_INSTRUMENT_ID:312283

Organización Internacional del Trabajo, OIT, Convenio OIT 154, sobre la negociación colectiva, Ginebra, 3 de junio de 1981. Disponible en: http://www.ilo.org/dyn/ normlex/es/f?p=1000:12100:0::NO:12100:P12100_INSTRUMENT_ID:312299

Organización Internacional del Trabajo, OIT, Convenio OIT 169, sobre pueblos indígenas y tribales, Ginebra, 27 de junio de 1989. Disponible en: http://www.ilo.org/dyn/ normlex/es/f?p=1000:12100:0::NO:12100:P12100_INSTRUMENT_ID:312314

Organización Internacional del Trabajo, OIT, Convenio OIT 182, sobre las peores formas de trabajo infantil, Ginebra, 17 de junio de 1999. Disponible en: http://www. ilo.org/dyn/normlex/es/f?p=1000:12100:0::NO:12100:P12100_INSTRUMENT_ ID:312327

Sociedad de las Naciones, SDN, Declaración de Ginebra sobre los Derechos del Niño, Ginebra, 24 de septiembre de 1924. Disponible en: http://www.un-documents.net/ gdrc1924.htm, http://www.humanium.org/fr/normes/declaration-de-geneve-1924/ texte-integral-declaration-de-geneve/

\section{Normatividad internacional}

Alemania, Ley Fundamental de la República Federal de Alemania [Grundgesetz für die Bundesrepublik Deutschland], Ley Fundamental de Bonn, 23 de mayo de 1949. Versión actualizada a 2010 disponible en: https://www.btg-bestellservice. de/pdf/80206000.pdf, https://www.bundestag.de/grundgesetz

Argentina, Constitución de la nación argentina, Ley 24.430, ordénase la publicación del texto oficial de la Constitución Nacional (sancionada en 1853 con las reformas de los años 1860, 1866, 1898, 1957 y 1994), 15 de diciembre de 1994. Disponible en: http://servicios.infoleg.gob.ar/infolegInternet/anexos/0-4999/804/norma.htm

Chile, Constitución, Decreto Supremo 100, 22 de septiembre de 2005, fija el texto refundido, coordinado y sistematizado de la Constitución Política de la República de Chile, 11 de septiembre de 1980. Disponible en: http://www.leychile.cl/ Navegar?id Norma $=242302$

España, Constitución de 1978, 311 Boletín Oficial del Estado, BOE, 29 de diciembre de 1978. Disponible en: http://www.boe.es/diario_boe/txt.php?id=BOE-A-1978-31229

España, Ley Orgánica 2/1979, de 3 de octubre de 1979, del Tribunal Constitucional, LOTC, 239 Boletín Oficial del Estado, BOE, 5 de octubre de 1979. Disponible en: https://www.boe.es/buscar/act.php?id=BOE-A-1979-23709 
España, Ley Orgánica 3/1979, de 18 de diciembre, de Estatuto de Autonomía para el País Vasco, 306 Boletín Oficial del Estado, BOE, 22 de diciembre de 1979. Disponible en: https://www.boe.es/buscar/pdf/1979/BOE-A-1979-30177-consolidado.pdf, https://www.boe.es/boe/dias/1979/12/22/pdfs/A29357-29363.pdf

España, Ley Orgánica 4/1979, de 18 de diciembre, de Estatuto de Autonomía de Cataluña, 306 Boletín Oficial del Estado, BOE, 22 de diciembre de 1979. Disponible en: https://www.boe.es/diario_boe/txt.php?id=BOE-A-1979-30178

España, Ley Orgánica 1/1981, de 6 de abril, de Estatuto de Autonomía para Galicia, 101 Boletín Oficial del Estado, BOE, 28 de abril de 1981. Disponible en: https:// www.boe.es/buscar/doc.php?id=BOE-A-1981-9564

España, Ley Orgánica 9/1992, de 6 de abril, de transferencia de competencias a Comunidades Autónomas que accedieron a la autonomía por la vía del artículo 143 de la Constitución, 308 Boletín Oficial del Estado, BOE, 24 de diciembre de 1992. Disponible en: https://www.boe.es/buscar/doc.php?id=BOE-A-1992-28426

Estados Unidos de América, Constitución, 7 de septiembre de 1787, ratificada 21 de junio de 1788. Disponible en: http://www.archives.gov/espanol/constitucion.html, http://www.senate.gov/civics/constitution_item/constitution.htm

Francia, Constitución, 27 de octubre de 1946 [Constitution de 1946, IVe République]. Disponible en: http://www.conseil-constitutionnel.fr/conseil-constitutionnel/ francais/la-constitution/les-constitutions-de-la-france/constitution-de-1946ive-republique.5109.html

Francia, Constitución, 4 de octubre de 1958 [Texte intégral de la Constitution du 4 octobre 1958 en vigueur]. Disponible en: http://www.justice.gouv.fr/art_pix/constitutionespagnol_juillet2008.pdf, http://www.conseil-constitutionnel.fr/conseilconstitutionnel/francais/la-constitution/la-constitution-du-4-octobre-1958/ texte-integral-de-la-constitution-du-4-octobre-1958-en-vigueur.5074.html

Francia, Loi constitutionnelle 2008-724, du 23 juillet 2008, de modernisation des institutions de la $V^{e}$ République, Journal Officiel, 24 juillet 2008. Disponible en: http://www.conseil-constitutionnel.fr/conseil-constitutionnel/francais/laconstitution/les-revisions-constitutionnelles/loi-constitutionnelle-n-2008-724du-23-juillet-2008.16312.html

Francia, Declaración de los Derechos del Hombre y del Ciudadano de 1789 [Déclaration des Droits de l'Homme et du Citoyen de 1789]. Disponible en: http://www.conseilconstitutionnel.fr/conseil-constitutionnel/root/bank_mm/espagnol/es_ddhc. pdf, https://www.legifrance.gouv.fr/Droit-francais/Constitution/Declarationdes-Droits-de-1-Homme-et-du-Citoyen-de-1789

Organización de Naciones Unidas, ONU, Comité de Derechos Económicos, Sociales y Culturales, CESCR, Observación general 14, 11 de agosto de 2000, El derecho al disfrute del más alto nivel posible de salud (artículo 12). Disponible en: http:// conf-dts1.unog.ch/1\%20SPA/Tradutek/Derechos_hum_Base/CESCR/00_1_obs_ grales_Cte $\% 20$ Dchos\%20Ec\%20Soc\%20Cult.html\#GEN14

Organización de Naciones Unidas, ONU, Comité de Derechos Económicos, Sociales y Culturales, CESCR, Observación general 19, 4 de febrero de 2008, El derecho a la seguridad social (artículo 9). Disponible en: http://conf-dtsl.unog.ch/1\%20SPA/ Tradutek/Derechos_hum_Base/CESCR/00_1_obs_grales_Cte $\% 20$ Dchos $\% 20$ Ec\%20Soc\%20Cult.html\#GEN19 
Organización de Naciones Unidas, ONU, Comité de los Derechos Humanos, Observación general 18, 10 de noviembre de 1989, No discriminación. Disponible en: http://www.acnur.org/t3/fileadmin/scripts/doc.php?file=t3/fileadmin/ Documentos/BDL/2001/1404, http://wwwl.umn.edu/humanrts/hrcommittee/ Sgencom18.html

Organización de Naciones Unidas, ONU, Comité para la Eliminación de la Discriminación contra la Mujer, CEDAW, Recomendación 19, 29 de enero de 1992. Disponible en: http://www.un.org/womenwatch/daw/cedaw/ recommendations/recomm-sp.htm

Organización de Naciones Unidas, ONU, Consejo de Seguridad, Resolución 1325, 31 de octubre de 2000. Disponible en: http://www.un.org/es/comun/docs/?symbol=S/ RES/1325(2000)

Perú, Constitución, 29 de diciembre de 1993. Disponible en: http://spij.minjus. gob.pe/CLP/contenidos.dll?f=templates $\& \mathrm{fn}=$ default-constitucion. htm\&vid=Ciclope:CLPdemo

Portugal, Constitución [Constituição da República Portuguesa], 2 de abril de 1976. Disponible en: http://www.redipd.org/legislacion/common/legislacion/portugal/ Constitucion_Portugal.pdf, http://www.parlamento.pt/Legislacao/Paginas/ ConstituicaoRepublicaPortuguesa.aspx

Sudáfrica, Constitución [Constitution of the Republic of South Africa, Act 108 of 1996], 18 de diciembre de 1996. Disponible en: http://www.gov.za/sites/www.gov.za/files/ images/a108-96.pdf, http://www.constitutionalcourt.org.za/site/theconstitution/ thetext.htm

\section{Normatividad colombiana}

Colombia, Constitución Política, 5 de agosto de 1886. Disponible en: http://www. alcaldiabogota.gov.co/sisjur/normas/Norma1.jsp?i=7153

Colombia, Constitución Política, segunda edición corregida, 116 Gaceta Constitucional, 20 de julio de 1991. Disponible en: http://www.secretariasenado.gov.co/senado/ basedoc/constitucion_politica_1991.html

Colombia, Decreto 1923 de 1978, por el cual se dictan normas para la protección de la vida, honra y bienes de las personas y se garantiza la seguridad de los asociados, 35.101 Diario Oficial, 21 de septiembre de 1978. Disponible en: https://www. minjusticia.gov.co/portals/0/MJD/docs/decreto_1923_1978.htm

Colombia, Decreto 250 de 1958, 11 de julio de 1958, por el cual se expide el Código de Justicia Penal Militar, 29.824 Diario Oficial, 25 de noviembre de 1958. Disponible en: http://www.suin-juriscol.gov.co/viewDocument.asp?id=1711708

Colombia, Decreto 2737 de 1989, por el cual se expide el Código del Menor, 39.080 Diario Oficial, 27 de noviembre de 1989. Disponible en: http://www.alcaldiabogota.gov. co/sisjur/normas/Norma1.jsp?i=4829

Colombia, Decreto Ley 2663, 5 de agosto de 1950, Código Sustantivo del Trabajo, 27.407 Diario Oficial, 9 de septiembre de 1950, en virtud del Estado de Sitio promulgado por el Decreto Extraordinario 3518 de 1949. Disponible en: http:// 
www.secretariasenado.gov.co/senado/basedoc/codigo_sustantivo_trabajo.html

Colombia, Ley 57 de 1887, Código Civil. Disponible en: http://www.secretariasenado. gov.co/senado/basedoc/codigo_civil.html

Colombia, Ley 51 de 1981, por medio de la cual se aprueba la Convención sobre la eliminación de todas las formas de discriminación contra la mujer, adoptada por la Asamblea General de las Naciones Unidas el 18 de diciembre de 1979 y firmada en Copenhague el 17 de julio de 1980, 35.794 Diario Oficial, 7 de julio de 1981. Disponible en: http://www.alcaldiabogota.gov.co/sisjur/normas/Norma1. jsp?i=14153

Colombia, Ley 12 de 1991, por medio de la cual se aprueba la Convención sobre los Derechos del Niño, adoptada por la Asamblea General de las Naciones Unidas el 20 de noviembre de 1989, 39.640 Diario Oficial, 22 de enero de 1991. Disponible en: http://www.alcaldiabogota.gov.co/sisjur/normas/Norma1.jsp?i=10579

Colombia, Ley 100 de 1993, por la cual se crea el sistema de seguridad social integral y se dictan otras disposiciones, 41.148 Diario Oficial, 23 de diciembre de 1993. Disponible en: http://www.secretariasenado.gov.co/senado/basedoc/ ley_0100_1993.html

Colombia, Ley 136 de 1994, por la cual se dictan normas tendientes a modernizar la organización y el funcionamiento de los municipios, 41.377 Diario Oficial, 2 de junio de 1994. Disponible en: http://www.secretariasenado.gov.co/senado/ basedoc/ley_0136_1994.html

Colombia, Ley 248 de 1995, por medio de la cual se aprueba la Convención Internacional para Prevenir, Sancionar y Erradicar la Violencia contra la Mujer, suscrita en la ciudad de Belém do Pará, Brasil, el 9 de junio de 1994, 42.171 Diario Oficial, 29 de diciembre de 1995. Disponible en: http://www.secretariasenado.gov.co/ senado/basedoc/ley_0136_1994.html

Colombia, Ley 789 de 2002, por la cual se dictan normas para apoyar el empleo y ampliar la protección social y se modifican algunos artículos del Código Sustantivo de Trabajo, 45.046 Diario Oficial, 27 de diciembre de 2002. Disponible en: http:// www.secretariasenado.gov.co/senado/basedoc/ley_0789_2002.html

Colombia, Ley 800 de 2003, por medio de la cual se aprueban la Convención de las Naciones Unidas contra la Delincuencia Organizada Transnacional y el Protocolo para Prevenir, Reprimir y Sancionar la Trata de Personas, especialmente Mujeres y Niños, que complementa la Convención de las Naciones Unidas contra la Delincuencia Organizada Transnacional, adoptados por la Asamblea General de las Naciones Unidas el 15 de noviembre de 2000, 45.131 Diario Oficial, 18 de marzo de 2003. Disponible en: http://www.secretariasenado. gov.co/senado/basedoc/ley_0800_2003.html

Colombia, Ley 984 de 2005, por medio de la cual se aprueba el Protocolo facultativo de la Convención sobre la eliminación de todas las formas de discriminación contra la mujer, adoptado por la Asamblea General de las Naciones Unidas el 6 de octubre de 1999, 46.002 Diario Oficial, 15 de agosto de 2005. Disponible en: http://www.secretariasenado.gov.co/senado/basedoc/ley_0984_2005.html

Colombia, Ley 1098 de 2006, por la cual se expide el Código de la Infancia y la Adolescencia, 46.446 Diario Oficial, 8 de noviembre de 2006. Disponible en: http://www.secretariasenado.gov.co/senado/basedoc/ley_1098_2006.html 
Colombia, Ley 1152 de 2007, por la cual se dicta el Estatuto de Desarrollo Rural, se reforma el Instituto Colombiano de Desarrollo Rural, Incoder, y se dictan otras disposiciones, 46.700 Diario Oficial, 25 de julio de 2007. Disponible en: http:// www.secretariasenado.gov.co/senado/basedoc/ley_1152_2007.html

\section{Jurisprudencia internacional}

Comunidad Andina, Comisión del Acuerdo de Cartagena, Decisión Andina 351 de 1993, Régimen Común sobre Derecho de Autor y Derechos Conexos, Lima, Perú, a los 17 de diciembre de 1993. Disponible en: http://www.sice.oas.org/trade/junac/ decisiones/dec351s.asp

España, Tribunal Constitucional, Pleno, Sentencia 42/1983, STC 42/1983, 20 de mayo de 1983, 144 Boletín Oficial del Estado, BOE, 17 de junio de 1983. Disponible en: http://www.tribunalconstitucional.es/es/jurisprudencia/Paginas/Sentencia. aspx?cod=16796

España, Tribunal Constitucional, Pleno, Sentencia 76/1983, STC 76/1983, 5 de agosto de 1983, 197 Boletín Oficial del Estado, BOE, 18 de agosto de 1983. Disponible en: http://www.tribunalconstitucional.es/es/jurisprudencia/Paginas/Sentencia. aspx?cod=16830

España, Tribunal Constitucional, Pleno, Sentencia 18/1991, STC 18/1991, 31 de enero de 1991, 48 Boletín Oficial del Estado, BOE, 25 de febrero de 1991. Disponible en: http://www.tribunalconstitucional.es/es/jurisprudencia/Paginas/Sentencia. aspx?cod=18283

España, Tribunal Constitucional, Pleno, Sentencia 128/1999, STC 128/1999, 1 de julio de 1999, 181 Boletin Oficial del Estado, BOE, 30 de julio de 1999. Disponible en: http://hj.tribunalconstitucional.es/es/Resolucion/Show/3870

España, Tribunal Constitucional, Pleno, Sentencia 208/1999, STC 208/1999, 11 de noviembre de 1999, 300 Boletín Oficial del Estado, BOE, 16 de diciembre de 1999. Disponible en: http://hj.tribunalconstitucional.es/es/Resolucion/Show/3950

España, Tribunal Constitucional, Pleno, Sentencia 45/2001, STC 45/2001, 15 de febrero de 2001, 65 Boletín Oficial del Estado, BOE, 16 de marzo de 2001. Disponible en: http://www.tribunalconstitucional.es/es/jurisprudencia/Paginas/Sentencia. aspx?cod=18283

España, Tribunal Constitucional, Pleno, Sentencia 38/2002, STC 38/2002, 14 de febrero de 2002, 63 Boletín Oficial del Estado, BOE, 14 de marzo de 2002. Disponible en: http://hj.tribunalconstitucional.es/es/Resolucion/Show/4574

España, Tribunal Constitucional, Pleno, Sentencia 198/2012, STC 198/2012, 6 de noviembre de 2012, 286 Boletín Oficial del Estado, BOE, 28 de noviembre de 2012. Disponible en: https://www.boe.es/diario_boe/txt.php?id=BOE-A-2012-14602

Francia, Conseil Constitutionnel, Décision 71-44 DC du 16 juillet 1971, Loi complétant les dispositions des articles 5 et 7 de la loi du 1 juillet 1901 relative au contrat d'association, Journal Officiel, 18 juillet 1971. Disponible en: http://www.conseilconstitutionnel.fr/conseil-constitutionnel/francais/les-decisions/acces-par-date/ decisions-depuis-1959/1971/71-44-dc/decision-n-71-44-dc-du-16-juillet-1971.7217. html 
Francia, Conseil Constitutionnel, Décision 73-51 DC du 27 décembre 1973, Loi de finances pour 1974, Journal Officiel, 28 décembre 1973. Disponible en: http:// www.conseil-constitutionnel.fr/conseil-con..decision-n-73-51-dc-du-27decembre-1973.7368.html

Francia, Conseil Constitutionnel, Décision 74-54 DC du 15 janvier 1975, Loi relative à l'interruption volontaire de la grossesse, Journal Officiel, 16 janvier 1975. Disponible en: http://www.conseil-constitutionnel.fr/conseil-constitutionnel/ francais/les-decisions/1975/74-54-dc/decision-n-74-54-dc-du-15-janvier-1975.7423. html

Francia, Conseil Constitutionnel, Décision 79-105 DC du 25 juillet 1979, Loi modifiant les dispositions de la loi 74-696 du 7 août 1974 relatives à la continuité du service public de la radio et de la télévision en cas de cessation concertée du travail, Journal Officiel, 27 juillet 1979. Disponible en: http://www.conseilconstitutionnel.fr/conseil-con..decision-n-79-105-dc-du-25-juillet-1979.7724.html

Francia, Conseil Constitutionnel, Décision 93-320 DC du 21 juin 1993, Loi de finances rectificative pour 1993, Journal Officiel, 23 juin 1993. Disponible en: http:// www.conseil-constitutionnel.fr/conseil-constitutionnel/francais/les-decisions/ acces-par-date/decisions-depuis-1959/1993/93-320-dc/decision-n-93-320-dc-du21-juin-1993.10485.html

Organización de Estados Americanos, OEA, Corte Interamericana de Derechos Humanos, CorteIDH, Ciertas atribuciones de la Comisión Interamericana de Derechos Humanos, Opinión Consultiva OC-13/93, 16 de julio de 1993, Serie A 13. Disponible en: http://www.corteidh.or.cr/docs/opiniones/seriea_13_esp.pdf

Organización de Estados Americanos, OEA, Corte Interamericana de Derechos Humanos, CorteIDH, Responsabilidad internacional por expedición y aplicación de leyes violatorias de la Convención, Opinión Consultiva OC-14/94, 9 de diciembre de 1994, Serie A 14. Disponible en: http://hrlibrary.umn.edu/iachr/loc-14.pdf

\section{Jurisprudencia colombiana}

Corte Constitucional, Sentencia C-472-92, 23 de julio de 1992, magistrado ponente José Gregorio Hernández-Galindo. Disponible en: http://corteconstitucional.gov.co/ relatoria/1992/c-472-92.htm

Corte Constitucional, Sentencia C-574-92, 28 de octubre de 1992, magistrado ponente Ciro Angarita-Barón. Disponible en: http://corteconstitucional.gov.co/ relatoria/1992/C-574-92.htm

Corte Constitucional, Sentencia C-027-93, 5 de febrero de 1993, magistrado ponente Simón Rodríguez-Rodríguez. Disponible en: http://corteconstitucional.gov.co/ relatoria/1993/c-027-93.htm

Corte Constitucional, Sentencia C-295-93, 29 de julio de 1993, magistrado ponente Carlos Gaviria-Díaz. Disponible en: http://corteconstitucional.gov.co/ relatoria/1993/c-295-93.htm

Corte Constitucional, Sentencia C-225-95, 18 de mayo de 1995, magistrado ponente Alejandro Martínez-Caballero. Disponible en: http://corteconstitucional.gov. co/relatoria/1995/c-225-95.htm 
Corte Constitucional, Sentencia C-423-95, 21 de septiembre de 1995, magistrado ponente Fabio Morón-Díaz. Disponible en: http://corteconstitucional.gov.co/ relatoria/1995/c-423-95.htm

Corte Constitucional, Sentencia C-578-95, 4 de diciembre de 1995, magistrado ponente Eduardo Cifuentes-Muñoz. Disponible en: http://corteconstitucional.gov.co/ relatoria/1995/c-578-95.htm

Corte Constitucional, Sentencia C-098-96, 7 de marzo de 1996, magistrado ponente Eduardo Cifuentes-Muñoz. Disponible en: http://corteconstitucional.gov.co/ relatoria/1996/c-098-96.htm

Corte Constitucional, Sentencia C-135-96, 9 de abril de 1996, magistrados ponentes Jorge Arango-Mejía, Eduardo Cifuentes-Muñoz, Alejandro Martínez-Caballero. Disponible en: http://corteconstitucional.gov.co/relatoria/1996/c-135-96.htm

Corte Constitucional, Sentencia C-239-97, 20 de mayo de 1997, magistrado ponente Carlos Gaviria-Díaz. Disponible en: http://www.corteconstitucional.gov.co/ relatoria/1997/c-239-97.htm

Corte Constitucional, Sentencia C-358-97, 5 de agosto de 1997, magistrado ponente Eduardo Cifuentes-Muñoz. Disponible en: http://www.corteconstitucional.gov. co/relatoria/1997/c-358-97.htm

Corte Constitucional, Sentencia C-191-98, 6 de mayo de 1998, magistrado ponente Eduardo Cifuentes-Muñoz. Disponible en: http://corteconstitucional.gov.co/ relatoria/1998/c-191-98.htm

Corte Constitucional, Sentencia C-256-98, 27 de mayo de 1998, magistrado ponente Fabio Morón-Díaz. Disponible en: http://www.corteconstitucional.gov.co/ relatoria/1998/c-256-98.htm

Corte Constitucional, Sentencia C-400-98, 10 de agosto de 1998, magistrado ponente Alejandro Martínez-Caballero. Disponible en: http://corteconstitucional.gov. co/relatoria/1998/c-400-98.htm

Corte Constitucional, Sentencia C-582-99, 11 de agosto de 1999, magistrado ponente Alejandro Martínez-Caballero. Disponible en: http://www.corteconstitucional. gov.co/relatoria/1999/c-582-99.htm

Corte Constitucional, Sentencia C-708-99, 22 de septiembre de 1999, magistrado ponente Álvaro Tafur-Galvis. Disponible en: http://www.corteconstitucional.gov.co/ relatoria/1999/c-708-99.htm

Corte Constitucional, Sentencia C-010-00, 19 de enero de 2000, magistrado ponente Alejandro Martínez-Caballero. Disponible en: http://www.corteconstitucional. gov.co/relatoria/2000/c-010-00.htm

Corte Constitucional, Sentencia C-177-01, 14 de febrero de 2001, magistrado ponente Fabio Morón-Díaz. Disponible en: http://www.corteconstitucional.gov.co/ relatoria/2001/c-177-01.htm

Corte Constitucional, Sentencia C-671-01, 28 de junio de 2001, magistrado ponente Jaime Araújo-Rentería. Disponible en: http://corteconstitucional.gov.co/ relatoria/2001/c-671-01.htm

Corte Constitucional, Sentencia C-418-02, 28 de mayo de 2002, magistrado ponente 
Álvaro Tafur-Galvis. Disponible en: http://www.corteconstitucional.gov.co/ relatoria/2002/c-418-02.htm

Corte Constitucional, Sentencia C-891-02, 22 de octubre de 2002, magistrado ponente Jaime Araújo-Rentería. Disponible en: http://www.corteconstitucional.gov.co/ relatoria/2002/c-891-02.htm

Corte Constitucional, Sentencia C-1066-02, 3 de diciembre de 2002, magistrado ponente Jaime Araújo-Rentería. Disponible en: http://www.corteconstitucional.gov.co/ relatoria/2002/c-1068-02.htm

Corte Constitucional, Sentencia C-1068-02, 3 de diciembre de 2002, magistrado ponente Jaime Araújo-Rentería. Disponible en: http://www.corteconstitucional.gov.co/ relatoria/2002/c-1068-02.htm

Corte Constitucional, Sentencia C-067-03, 4 de febrero de 2003, magistrado ponente Marco Gerardo Monroy-Cabra. Disponible en: http://www.corteconstitucional. gov.co/relatoria/2003/c-067-03.htm

Corte Constitucional, Sentencia C-205-03, 11 de marzo de 2003, magistrada ponente Clara Inés Vargas-Hernández. Disponible en: http://www.corteconstitucional. gov.co/relatoria/2003/c-205-03.htm

Corte Constitucional, Sentencia C-129-04, 19 de febrero de 2004, magistrado ponente Marco Gerardo Monroy-Cabra. Disponible en: http://www.corteconstitucional. gov.co/relatoria/2004/c-129-04.htm

Corte Constitucional, Sentencia C-170-04, 2 de marzo de 2004, magistrado ponente Rodrigo Escobar-Gil. Disponible en: http://www.corteconstitucional.gov.co/ relatoria/2004/c-170-04.htm

Corte Constitucional, Sentencia C-988-04, 12 de octubre de 2004, magistrado ponente Humberto Sierra-Porto. Disponible en: http://www.corteconstitucional.gov.co/ relatoria/2004/c-988-04.htm

Corte Constitucional, Sentencia C-997-04, 12 de octubre de 2004, magistrado ponente Jaime Córdoba-Triviño. Disponible en: http://www.corteconstitucional.gov.co/ relatoria/2004/c-997-04.htm

Corte Constitucional, Sentencia C-035-05, 25 de enero de 2005, magistrado ponente Rodrigo Escobar-Gil. Disponible en: http://www.corteconstitucional.gov.co/ relatoria/2005/c-035-05.htm

Corte Constitucional, Sentencia C-148-05, 22 de febrero de 2005, magistrado ponente Álvaro Tafur-Galvis. Disponible en: http://www.corteconstitucional.gov.co/ relatoria/2005/c-148-05.htm

Corte Constitucional, Sentencia C-203-05, 8 de marzo de 2005, magistrado ponente Manuel José Cepeda-Espinosa. Disponible en: http://www.corteconstitucional. gov.co/relatoria/2005/c-203-05.htm

Corte Constitucional, Sentencia C-401-05, 14 de abril de 2005, magistrado ponente Manuel José Cepeda-Espinosa. Disponible en: http://www.corteconstitucional. gov.co/relatoria/2005/c-401-05.htm

Corte Constitucional, Sentencia C-1118-05, 1 de noviembre de 2005, magistrada ponente Clara Inés Vargas-Hernández. Disponible en: http://www.corteconstitucional. 
gov.co/relatoria/2005/c-1118-05.htm

Corte Constitucional, Sentencia C-1188-05, 22 de noviembre de 2005, magistrado ponente Alfredo Beltrán-Sierra. Disponible en: http://www.corteconstitucional.gov.co/ relatoria/2005/c-1188-05.htm

Corte Constitucional, Sentencia C-1197-05, 22 de noviembre de 2005, magistrado ponente Humberto Sierra-Porto. Disponible en: http://www.corteconstitucional.gov.co/ relatoria/2005/c-1197-05.htm

Corte Constitucional, Sentencia C-118-06, 22 de febrero de 2006, magistrado ponente Jaime Araújo-Rentería. Disponible en: http://www.corteconstitucional.gov.co/ relatoria/2006/c-118-06.htm

Corte Constitucional, Sentencia C-187-06, 15 de marzo de 2006, magistrada ponente Clara Inés Vargas-Hernández. Disponible en: http://www.corteconstitucional. gov.co/relatoria/2006/c-187-06.htm

Corte Constitucional, Sentencia C-339-06, 3 de mayo de 2006, magistrado ponente Jaime Córdoba-Triviño. Disponible en: http://www.corteconstitucional.gov.co/ relatoria/2006/c-339-06.htm

Corte Constitucional, Sentencia C-355-06, 10 de mayo de 2006, magistrados ponentes Jaime Araújo-Rentería, Clara Inés Vargas-Hernández. Disponible en: http:// www.corteconstitucional.gov.co/relatoria/2006/c-355-06.htm

Corte Constitucional, Sentencia C-370-06, 18 de mayo de 2006, magistrados ponentes Manuel José Cepeda-Espinosa, Jaime Córdoba-Triviño, Rodrigo EscobarGil, Marco Gerardo Monroy-Cabra, Álvaro Tafur-Galvis, Clara Inés Vargas-Hernández. Disponible en: http://www.corteconstitucional.gov.co/ relatoria/2006/c-370-06.htm

Corte Constitucional, Sentencia C-575-06, 25 de julio de 2006, magistrado ponente Álvaro Tafur-Galvis. Disponible en: http://www.corteconstitucional.gov.co/ relatoria/2006/c-575-06.htm

Corte Constitucional, Sentencia C-667-06, 16 de agosto de 2006, magistrado ponente Jaime Araújo-Rentería. Disponible en: http://www.corteconstitucional.gov.co/ relatoria/2006/c-575-06.htm

Corte Constitucional, Sentencia C-864-06, 19 de octubre de 2006, magistrado ponente Rodrigo Escobar-Gil. Disponible en: http://www.corteconstitucional.gov.co/ relatoria/2006/c-864-06.htm

Corte Constitucional, Sentencia C-075-07, 7 de febrero de 2007, magistrado ponente Rodrigo Escobar-Gil. Disponible en: http://corteconstitucional.gov.co/ relatoria/2007/c-075-07.htm

Corte Constitucional, Sentencia C-155-07, 7 de marzo de 2007, magistrado ponente Álvaro Tafur-Galvis. Disponible en: http://www.corteconstitucional.gov.co/ relatoria/2007/c-155-07.htm

Corte Constitucional, Sentencia C-208-07, 21 de marzo de 2007, magistrado ponente Rodrigo Escobar-Gil. Disponible en: http://www.corteconstitucional.gov.co/ relatoria/2007/c-208-07.htm

Corte Constitucional, Sentencia C-278-07, 18 de abril de 2007, magistrado ponente 
Nilson Pinilla-Pinilla. Disponible en: http://www.corteconstitucional.gov.co/ relatoria/2007/c-278-07.htm

Corte Constitucional, Sentencia C-291-07, 25 de abril de 2007, magistrado ponente Manuel José Cepeda-Espinosa. Disponible en: http://www.corteconstitucional. gov.co/relatoria/2007/c-291-07.htm

Corte Constitucional, Sentencia C-502-07, 4 de julio de 2007, magistrado ponente Manuel José Cepeda-Espinosa. Disponible en: http://www.corteconstitucional.gov.co/ relatoria/2007/c-502-07.htm

Corte Constitucional, Sentencia C-809-07, 3 de octubre de 2007, magistrado ponente Manuel José Cepeda-Espinosa. Disponible en: http://www.corteconstitucional. gov.co/relatoria/2007/c-809-07.htm

Corte Constitucional, Sentencia C-1003-07, 22 de noviembre de 2007, magistrada ponente Clara Inés Vargas-Hernández. Disponible en: http://www.corteconstitucional. gov.co/relatoria/2007/c-1003-07.htm

Corte Constitucional, Sentencia C-030-08, 23 de enero de 2008, magistrado ponente Rodrigo Escobar-Gil. Disponible en: http://www.corteconstitucional.gov.co/ relatoria/2008/c-030-08.htm

Corte Constitucional, Sentencia C-466-08, 14 de mayo de 2008, magistrado ponente Jaime Araújo-Rentería. Disponible en: http://www.corteconstitucional.gov.co/ relatoria/2008/c-466-08.htm

Corte Constitucional, Sentencia C-750-08, 24 de julio de 2008, magistrada ponente Clara Inés Vargas-Hernández. Disponible en: http://www.corteconstitucional. gov.co/relatoria/2008/c-750-08.htm

Corte Constitucional, Sentencia C-029-09, 28 de enero de 2009, magistrado ponente Rodrigo Escobar-Gil. Disponible en: http://www.corteconstitucional.gov.co/ relatoria/2009/c-029-09.htm

Corte Constitucional, Sentencia C-175-09, 18 de marzo de 2009, magistrado ponente Luis Ernesto Vargas-Silva. Disponible en: http://www.corteconstitucional.gov. co/relatoria/2009/c-175-09.htm

Corte Constitucional, Sentencia C-240-09, 1 de abril de 2009, magistrado ponente Mauricio González-Cuervo. Disponible en: http://www.corteconstitucional. gov.co/relatoria/2009/c-240-09.htm

Corte Constitucional, Sentencia C-307-09, 29 de abril de 2009, magistrado ponente Jorge Iván Palacio-Palacio. Disponible en: http://www.corteconstitucional.gov. co/relatoria/2009/c-307-09.htm

Corte Constitucional, Sentencia C-349-09, 20 de mayo de 2009, magistrado ponente Luis Ernesto Vargas-Silva. Disponible en: http://www.corteconstitucional.gov. co/relatoria/2009/c-349-09.htm

Corte Constitucional, Sentencia C-375-09, 27 de mayo de 2009, magistrado ponente Nilson Pinilla-Pinilla. Disponible en: http://www.corteconstitucional.gov.co/ relatoria/2009/C-375-09.htm

Corte Constitucional, Sentencia C-488-09, 22 de julio de 2009, magistrado ponente Jorge Iván Palacio-Palacio. Disponible en: http://www.corteconstitucional.gov. 
co/relatoria/2009/c-488-09.htm

Corte Constitucional, Sentencia C-433-10, 2 de junio de 2010, magistrado ponente Humberto Antonio Sierra Porto. Disponible en: http://www.corteconstitucional. gov.co/relatoria/2010/c-433-10.htm

Corte Constitucional, Sentencia C-577-11, 26 de julio de 2011, magistrado ponente Gabriel Eduardo Mendoza-Martelo. Disponible en: http://corteconstitucional. gov.co/relatoria/2011/c-577-11.htm

Corte Constitucional, Sentencia C-249-12, 29 de marzo de 2012, magistrado ponente Juan Carlos Henao-Pérez. Disponible en: http://www.corteconstitucional.gov. co/relatoria/2012/c-249-12.htm

Corte Constitucional, Sentencia C-438-13, 10 de julio de 2013, magistrado ponente Alberto Rojas-Ríos. Disponible en: http://www.corteconstitucional.gov.co/ relatoria/2013/c-438-13.htm

Corte Constitucional, Sentencia C-500-14, 16 de julio de 2014, magistrado ponente Mauricio González-Cuervo. Disponible en: http://www.corteconstitucional. gov.co/relatoria/2014/c-500-14.htm

Corte Constitucional, Sentencia SU-039-97, 3 de febrero de 1997, magistrado ponente Antonio Barrera-Carbonell. Disponible en: http://www.corteconstitucional.gov. co/relatoria/1997/su039-97.htm

Corte Constitucional, Sentencia SU-195-98, 7 de mayo de 1998, magistrado ponente Vladimiro Naranjo-Mesa. Disponible en: http://corteconstitucional.gov.co/ relatoria/1998/su195-98.htm

Corte Constitucional, Sentencia T-409-92, 8 de junio de 1992, magistrados ponentes Alejandro Martínez Caballero, Fabio Morón Díaz. Disponible en: http://www. corteconstitucional.gov.co/relatoria/1992/t-409-92.htm

Corte Constitucional, Sentencia T-411-92, 17 de junio de 1992, magistrado ponente Alejandro Martínez-Caballero. Disponible en: http://www.corteconstitucional. gov.co/relatoria/1992/t-411-92.htm

Corte Constitucional, Sentencia T-426-92, 24 de junio de 1992, magistrado ponente Eduardo Cifuentes-Muñoz. Disponible en: http://corteconstitucional.gov.co/ relatoria/1992/t-426-92.htm

Corte Constitucional, Sentencia T-092-93, 19 de febrero de 1993, magistrado ponente Simón Rodríguez-Rodríguez. Disponible en: http://corteconstitucional.gov.co/ relatoria/1993/t-092-93.htm

Corte Constitucional, Sentencia T-254-93, 30 de junio de 1993, magistrado ponente Antonio Barrera-Carbonell. Disponible en: http://corteconstitucional.gov.co/ relatoria/1993/t-254-93.htm

Corte Constitucional, Sentencia T-510-93, 8 de noviembre de 1993, magistrado ponente Vladimiro Naranjo-Mesa. Disponible en: http://www.corteconstitucional.gov. co/relatoria/1993/t-510-93.htm

Corte Constitucional, Sentencia T-004-95, 16 de enero de 1995, magistrado ponente José Gregorio Hernández-Galindo. Disponible en: http://corteconstitucional. gov.co/relatoria/1995/t-004-95.htm 
Corte Constitucional, Sentencia T-408-95, 12 de septiembre de 1995, magistrado ponente Eduardo Cifuentes-Muñoz. Disponible en: http://www.corteconstitucional.gov. co/relatoria/1995/t-408-95.htm

Corte Constitucional, Sentencia T-477-95, 23 de octubre de 1995, magistrado ponente Alejandro Martínez-Caballero. Disponible en: http://www.corteconstitucional. gov.co/relatoria/1995/t-477-95.htm

Corte Constitucional, Sentencia T-041-96, 7 de febrero de 1996, magistrado ponente Carlos Gaviria-Díaz. Disponible en: http://www.corteconstitucional.gov.co/ relatoria/1996/t-041-96.htm

Corte Constitucional, Sentencia T-459-98, 2 de septiembre de 1998, magistrado ponente Vladimiro Naranjo-Mesa. Disponible en: http://www.corteconstitucional.gov. co/relatoria/1998/t-459-98.htm

Corte Constitucional, Sentencia T-652-98, 10 de noviembre de 1998, magistrado ponente Carlos Gaviria-Díaz. Disponible en: http://www.corteconstitucional.gov.co/ relatoria/1998/t-652-98.htm

Corte Constitucional, Sentencia T-046-99, 29 de enero de 1999, magistrado ponente Hernando Herrera-Vergara. Disponible en: http://corteconstitucional.gov.co/ relatoria/1999/t-046-99.htm

Corte Constitucional, Sentencia T-483-99, 8 de julio de 1999, magistrado ponente Antonio Barrera-Carbonell. Disponible en: http://www.corteconstitucional. gov.co/relatoria/1999/t-483-99.htm

Corte Constitucional, Sentencia T-568-99, 10 de agosto de 1999, magistrado ponente Carlos Gaviria-Díaz. Disponible en: http://www.corteconstitucional.gov.co/ relatoria/1999/t-568-99.htm

Corte Constitucional, Sentencia T-375-00, 30 de marzo de 2000, magistrado ponente Vladimiro Naranjo-Mesa. Disponible en: http://www.corteconstitucional.gov. co/relatoria/2000/t-375-00.htm

Corte Constitucional, Sentencia T-911-00, 17 de julio de 2000, magistrado ponente Alejandro Martínez-Caballero. Disponible en: http://www.corteconstitucional. gov.co/relatoria/2000/t-911-00.htm

Corte Constitucional, Sentencia T-934-00, 24 de julio de 2000, magistrado ponente Alejandro Martínez-Caballero. Disponible en: http://www.corteconstitucional. gov.co/relatoria/2000/t-934-00.htm

Corte Constitucional, Sentencia T-1247-00, 7 de septiembre de 2000, magistrado ponente Alejandro Martínez-Caballero. Disponible en: http://www.corteconstitucional. gov.co/relatoria/2000/t-1247-00.htm

Corte Constitucional, Sentencia T-1558-00, 21 de noviembre de 2000, magistrado ponente Fabio Morón-Díaz. Disponible en: http://www.corteconstitucional.gov. co/relatoria/2000/t-1558-00.htm

Corte Constitucional, Sentencia T-040A-01, 22 de enero de 2001, magistrado ponente Fabio Morón-Díaz. Disponible en: http://corteconstitucional.gov.co/ relatoria/2001/T-040A-01.htm

Corte Constitucional, Sentencia T-367-01, 3 de abril de 2001, magistrado ponente 
Jaime Araújo-Rentería. Disponible en: http://corteconstitucional.gov.co/ relatoria/2001/t-367-01.htm

Corte Constitucional, Sentencia T-664-01, 27 de junio de 2001, magistrado ponente Jaime Araújo-Rentería. Disponible en: http://corteconstitucional.gov.co/ relatoria/2001/t-664-01.htm

Corte Constitucional, Sentencia T-693-01, 4 de julio de 2001, magistrado ponente Jaime Araújo-Rentería. Disponible en: http://www.corteconstitucional.gov.co/ relatoria/2001/t-693-01.htm

Corte Constitucional, Sentencia T-697-01, 5 de julio de 2001, magistrado ponente Álvaro Tafur-Galvis. Disponible en: http://corteconstitucional.gov.co/ relatoria/2001/t-697-01.htm

Corte Constitucional, Sentencia T-1040-01, 27 de septiembre de 2001, magistrado ponente Rodrigo Escobar-Gil. Disponible en: http://corteconstitucional.gov. co/relatoria/2001/t-1040-01.htm

Corte Constitucional, Sentencia T-161-02, 7 de marzo de 2002, magistrado ponente Álvaro Tafur-Galvis. Disponible en: http://corteconstitucional.gov.co/ relatoria/2002/t-161-02.htm

Corte Constitucional, Sentencia T-189-03, 5 de marzo de 2003, magistrado ponente Alfredo Beltrán-Sierra. Disponible en: http://www.corteconstitucional.gov.co/ relatoria/2003/t-189-03.htm

Corte Constitucional, Sentencia T-510-03, 19 de junio de 2003, magistrado ponente Manuel José Cepeda-Espinosa. Disponible en: http://www.corteconstitucional. gov.co/relatoria/2003/t-510-03.htm

Corte Constitucional, Sentencia T-602-03, 23 de julio de 2003, magistrado ponente Jaime Araújo-Rentería. Disponible en: http://www.corteconstitucional.gov.co/ relatoria/2003/t-602-03.htm

Corte Constitucional, Sentencia T-859-03, 25 de septiembre de 2003, magistrado ponente Eduardo Montealegre-Lynett. Disponible en: http://www.corteconstitucional. gov.co/relatoria/2003/t-859-03.htm

Corte Constitucional, Sentencia T-397-04, 29 de abril de 2004, magistrado ponente Manuel José Cepeda-Espinosa. Disponible en: http://www.corteconstitucional. gov.co/relatoria/2004/t-397-04.htm

Corte Constitucional, Sentencia T-900-04, 16 de septiembre de 2004, magistrado ponente Jaime Córdoba-Triviño. Disponible en: http://corteconstitucional.gov. co/relatoria/2004/t-900-04.htm

Corte Constitucional, Sentencia T-979-04, 8 de octubre de 2004, magistrado ponente Jaime Córdoba-Triviño. Disponible en: http://www.corteconstitucional.gov.co/ relatoria/2004/t-979-04.htm

Corte Constitucional, Sentencia T-864-05, 18 de agosto de 2005, magistrado ponente Álvaro Tafur-Galvis. Disponible en: http://www.corteconstitucional.gov.co/ relatoria/2005/t-864-05.htm

Corte Constitucional, Sentencia T-285-06, 5 de abril de 2006, magistrado ponente Álvaro Tafur-Galvis. Disponible en: http://www.corteconstitucional.gov.co/ 
relatoria/2006/t-285-06.htm

Corte Constitucional, Sentencia T-551-06, 13 de julio de 2006, magistrado ponente Marco Gerardo Monroy-Cabra. Disponible en: http://www.corteconstitucional. gov.co/relatoria/2006/t-551-06.htm

Corte Constitucional, Sentencia T-808-06, 28 de septiembre de 2006, magistrado ponente Manuel José Cepeda-Espinosa. Disponible en: http://www.corteconstitucional. gov.co/relatoria/2006/t-808-06.htm

Corte Constitucional, Sentencia T-056-08, 25 de enero de 2008, magistrado ponente Jaime Córdoba-Triviño. Disponible en: http://www.corteconstitucional.gov.co/ relatoria/2008/t-056-08.htm

Corte Constitucional, Sentencia T-658-08, 1 de julio de 2008, magistrado ponente Humberto Antonio Sierra-Porto. Disponible en: http://www.corteconstitucional. gov.co/relatoria/2008/t-658-08.htm

Corte Constitucional, Sentencia T-703-08, 10 de julio de 2008, magistrado ponente Manuel José Cepeda-Espinosa. Disponible en: http://www.corteconstitucional. gov.co/relatoria/2008/t-703-08.htm

Corte Constitucional, Sentencia T-760-08, 31 de julio de 2008, magistrado ponente Manuel José Cepeda-Espinosa. Disponible en: http://www.corteconstitucional. gov.co/relatoria/2015/t-760-08.htm

Corte Constitucional, Sentencia T-1134-08, 14 de noviembre de 2008, magistrado ponente Manuel José Cepeda-Espinosa. Disponible en: http://www.corteconstitucional. gov.co/relatoria/2008/t-1134-08.htm

Corte Constitucional, Sentencia T-006-09, 16 de enero de 2009, magistrado ponente Jaime Córdoba-Triviño. Disponible en: http://www.corteconstitucional.gov.co/ relatoria/2009/t-006-09.htm

Corte Constitucional, Sentencia T-042-09, 29 de enero de 2009, magistrado ponente Jaime Córdoba-Triviño. Disponible en: http://www.corteconstitucional.gov.co/ relatoria/2009/t-042-09.htm

Corte Constitucional, Sentencia T-319-09, 7 de mayo de 2009, magistrado ponente Jorge Iván Palacio-Palacio. Disponible en: http://www.corteconstitucional.gov.co/ relatoria/2009/t-319-09.htm

Corte Constitucional, Sentencia T-539-09, 6 de agosto de 2009, magistrado ponente Humberto Antonio Sierra-Porto. Disponible en: http://www.corteconstitucional. gov.co/relatoria/2009/t-539-09.htm

Corte Constitucional, Sentencia T-732-09, 15 de octubre de 2009, magistrado ponente Humberto Antonio Sierra-Porto. Disponible en: http://www.corteconstitucional. gov.co/relatoria/2009/t-732-09.htm

Corte Constitucional, Sentencia T-078-10, 11 de febrero de 2010, magistrado ponente Luis Ernesto Vargas-Silva. Disponible en: http://www.corteconstitucional.gov. co/relatoria/2010/t-078-10.htm

Corte Constitucional, Sentencia T-129-11, 3 de marzo de 2011, magistrado ponente Jorge Iván Palacio-Palacio. Disponible en: http://www.corteconstitucional.gov. co/relatoria/2011/t-129-11.htm 
Corte Constitucional, Sentencia T-069-14, 3 de febrero de 2014, magistrada ponente María Victoria Calle-Correa. Disponible en: http://www.corteconstitucional. gov.co/relatoria/2014/T-069-14.htm

Corte Constitucional, Sentencia T-201-14, 1 de abril de 2014, magistrado ponente Alberto Rojas-Ríos. Disponible en: http://www.corteconstitucional.gov.co/ relatoria/2014/t-201-14.htm

Corte Constitucional, Sentencia T-749-14, 8 de octubre de 2014, magistrado ponente Jorge Iván Palacio-Palacio. Disponible en: http://corteconstitucional.gov.co/ relatoria/2014/t-749-14.htm

Corte Constitucional, Sentencia T-878-14, 18 de noviembre de 2014, magistrado ponente Jorge Iván Palacio-Palacio. Disponible en: http://www.corteconstitucional.gov. co/relatoria/2014/t-878-14.htm

\section{Medios de comunicación}

El pueblo colombiano que no quiere oro. Los habitantes de Piedras, en Tolima, rechazaron con un referendo el proyecto de explotación aurifera más grande de Colombia. ¿Los escucharán?, El Comercio, 31 de julio de 2013. Disponible en: http://elcomercio. pe/mundo/actualidad/pueblo-colombiano-que-no-quiere-oro-noticia-1611240 
